\title{
Flora and vegetation of the southern Carnarvon Basin, Western Australia
}

\author{
G.J. Keighery, N. Gibson, M.N. Lyons and Allan H. Burbidge \\ Department of Conservation and Land Management, PO Box 51, Wanneroo, \\ Western Australia 6065, Australia
}

\begin{abstract}
This paper reports the first detailed study of the vascular flora of the southern Carnarvon Basin, an area of c. $75000 \mathrm{~km}^{2}$. A total flora of 2133 taxa of vascular plants was listed for the area. There are eight major conservation reserves which have 1559 taxa present in them. Most of the 574 unreserved taxa are wetland taxa, taxa of tropical affinities or those only present on the Acacia shrublands of the central basin. Vegetation patterning at a regional scale showed the major floristic boundary in the south west of the study area, which in turn reflected the major climatic gradients of the area. The other major influence on vegetation patterning was soil type.
\end{abstract}

\section{INTRODUCTION}

Despite Shark Bay being the site of very early visitation and study by several European expeditions (Beard, 1990; Keighery, 1990; George, 1999) the area was until recently still poorly known botanically. Beard $(1975,1976 a)$ prepared structural vegetation maps for the whole area at a 1:1000 000 scale and Payne et al. (1987) have undertaken land system maps (rangeland mapping) for the whole area at a 1: 250000 scale. More localised areas have been mapped and published for the Kalbarri-Shark Bay area by Beard $(1976 b, 1976 \mathrm{c})$ at a scale of 1: 250000 .

Limited floristic surveys have been undertaken in the north of the study area around Lake MacLeod by Tyler (1988), Rocky Pool near Carnarvon by Kenneally (1978) and Cape Range by Keighery and Gibson (1993). Other localised studies have involved the Shark Bay World Heritage Area by Trudgen and Keighery (1995), Bernier and Dorre Islands by Royce (1962), Dirk Hartog Island by Burbidge and George (1978), Kennedy Range by Newbey and Newbey (1992) and Toolonga Nature Reserve by Burbidge et al. (1980).

The present work is part of a multi-disciplinary study to sample the biodiversity of a $75000 \mathrm{~km}^{2}$ region of Western Australia (the southern Carnarvon Basin) and identify biophysical factors related to the observed patterns of species distribution (Burbidge et al., 2000).

The aim of this paper is to describe the flora and vegetation of the major landforms sampled as biodiversity sites and to discuss the composition, biogeographic patterns and conservation status of the vascular plants of the study area. Related papers in this volume deal with the wetland flora (Gibson, Keighery and Lyons, 2000) and the flora of the temperate - arid change-over zone (Gibson, Burbidge, Keighery and Lyons, 2000).

\section{METHODS}

\section{Study area}

The study area covered by the flora survey extended from $23^{\circ} 30^{\prime} \mathrm{S}$ to $28^{\circ} 00^{\prime} \mathrm{S}$ and from Dirk Hartog Island and Shark Bay in the west to $115^{\circ} 30^{\prime} \mathrm{E}$ (Figure 1). The southwest of the study area encompasses the change over from the South West Botanical Province to the Eremaean Province and hence is an area of major vegetation change. Almost the entire study area falls within the Carnarvon and Irwin botanical districts of Beard (1990). These districts largely correspond to two IBRA regions Geraldton Sandplain and Carnarvon (Thackway and Cresswell, 1995).

\section{Field sampling and analysis}

Sixty-three primary sites were sampled across the study area, stratified to cover the geographic range of the major surface types of the Basin. Sites were selected such that three to five different surfacetypes could be sampled in close proximity to facilitate fauna sampling (Figure 1). Sites $30 \mathrm{~m} \times 30$ $m$ were established at each site and all vascular plants occurring in the sites were recorded. Sites were visited twice, in August 1994 and August 1995. Some additional recordings were made when the sites were visited at other times in conjunction with fauna sampling. Sites were classified according to similarities in species composition (presence/absence data) using the Czekanowski coefficient and 'unweighted pair-group mean average' fusion method (UPGMA, Sneath and 


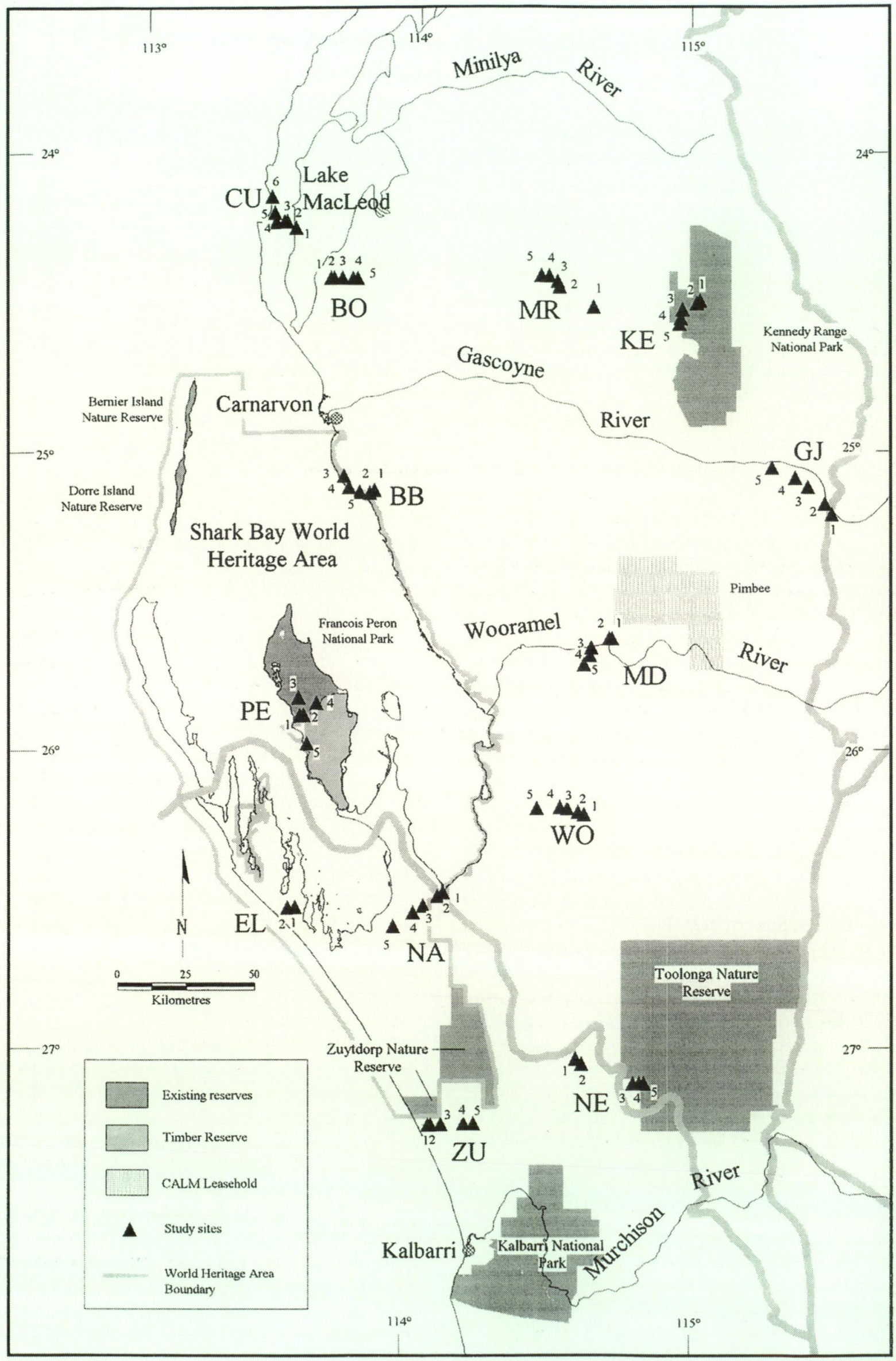

Figure 1 Location of 63 primary sampling sites and major conservation reserves in the study area. 
Sokal, 1973), while species were classified using the 'two step' method of Austin and Belbin (1982) and the UPGMA fusion method. Only taxa identified to species level were included in the analysis $(>95 \%$ records). Annuals and geophytes were included in the analysis because all sites but one (NE2) were considered to have had good rains prior to at least one of the sampling periods.

A bulked soil sample (consisting of 24 regularly spaced subsamples across the site) of the top $10 \mathrm{~cm}$ was collected from each site, and soil mechanical analysis and macro nutrient analyses were undertaken on these samples [see McArthur (1991) for details]. Eleven climatic parameters for each site were estimated from the climate modelling program ANUCLIM (McMahon et al., 1995). Statistical relationships between site groups were tested using Kruskal - Wallis non-parametric analysis of variance and Mann Whitney U-tests (Siegel, 1956).

In addition to the 63 primary sites, flora lists were available from 75 extra sites in the southern part of the study area (Gibson, Burbidge, Keighery and Lyons, 2000) and from the wetland survey (Gibson, Keighery and Lyons, 2000). Additional sampling efforts in six mainland reserves were also undertaken to compile comprehensive species lists for the eight major reserves (Figure 1) in the study area. These lists also include previously published surveys and collections held in the Western Australian Herbarium (PERTH). The total known vascular flora of the study area (Appendix 1) was compiled from the current and previous surveys, and from collections held in PERTH.

Nomenclature generally follows Green (1985) and current usage at PERTH. Over 2200 voucher specimens have been lodged in PERTH.

\section{RESULTS}

The results are given in two sections. The first deals with the overall vascular flora recorded for the study area, its composition and conservation. It provides a floristic context for the interpretation of the second part, which deals with quantitative patterns in the floristic composition of the biodiversity sites and how this patterning relates to the biophysical attributes of the study area.

\section{Flora}

\section{Composition}

A total of 2133 taxa of vascular plants from 122 families were recorded from the study area (Appendix 1). These comprised 9 ferns or fern allies, 2 gymnosperms and 2122 flowering plants (of which 88 were naturalised aliens).

The largest families were the Myrtaceae (231 taxa, $10.8 \%$ of the flora), Asteraceae (181 taxa, 8.5\%), Poaceae (168 taxa, 7.9\%), Chenopodiaceae (106,
$5.0 \%)$, Papilionaceae $(105,4.9 \%)$, Mimosaceae (95, $4.5 \%)$, Proteaceae $(93,4.4 \%)$, Goodeniaceae $(71$, $3.3 \%)$, Cyperaceae $(61,2.9 \%)$, Orchidaceae $(57$, $2.7 \%)$, Amaranthaceae $(50,2.3 \%)$, Myoporaceae $(50$, $2.3 \%$ ) and Malvaceae $(48,2.3 \%)$. Together these 13 families comprise $51.7 \%$ of the total flora.

Of the remaining 109 families, only 12 contained at least 20 species: Euphorbiaceae (36 taxa), Brassicaceae (32), Solanaceae (32), Anthericaceae (28), Zygophyllaceae (26), Apiaceae (22), Epacridaceae (22), Sterculiaceae (22), Boraginaceae (21), Chloanthaceae (21), Haemodoraceae (20) and Portulacaceae (20). These 12 families combined contributed $14.2 \%$ of the total flora.

Several significant collections were made during the survey, including the re-collection of Rumex crystallinus (the first record since 1877). Three apparently new taxa were first collected during the survey: Paracaleana lyonsii ms (Orchidaceae), Calandrinia sp. Coolcalalaya (GK and NG 698) (Portulacaceae) and Eremophila glabra subsp. Zuytdorp (GK and NG 518) (Myoporaceae).

The broad composition of the flora reflects the major climatic influences affecting the study area. There is a southern coastal winter rainfall zone and an inland and northern arid zone. The whole study area is still dominated by winter rainfall (Wyrwoll, Courtney and Sandercock, 2000). Immediately north of the study area, summer rainfall begins to dominate. The majority of the study area is arid and forms part of the Eremaean Botanical Province (Beard, 1975, 1976a). This pattern is also clearly seen in the results for the vegetation analysis (see below).

This strong desert influence is clearly demonstrated in the composition of the flora, with arid zone taxa dominating in six of the speciose families (Amaranthaceae, Asteraceae, Goodeniaceae, Malvaceae, Myoporaceae and Poaceae) and in nearly all the smaller families (Euphorbiaceae, Brassicaceae, Solanaceae, Zygophyllaceae, Apiaceae, Sterculiaceae, Boraginaceae, Chloanthaceae, and Portulacaceae). These desert influences are from predominantly temperate or winter rainfall semi-arid or arid areas, rather than a tropical desert flora. This can be illustrated using the Asteraceae, the largest family recorded from the study area.

The family has 492 native taxa present in Western Australia, of which 181 were recorded from the study area. Species richness in the family is greatest in the Avon-Wheatbelt and Coolgardie IBRA regions (areas of Mediterranean and arid-Mediterranean climate) of Western Australia (Figure 2). The family, though spread widely through the arid zone (providing the spectacular wildflower displays of the Acacia shrublands) and tropics, is species rich in temperate Western Australia.

The Asteraceae of the study area are a reflection of the above pattern, being comprised mainly of 


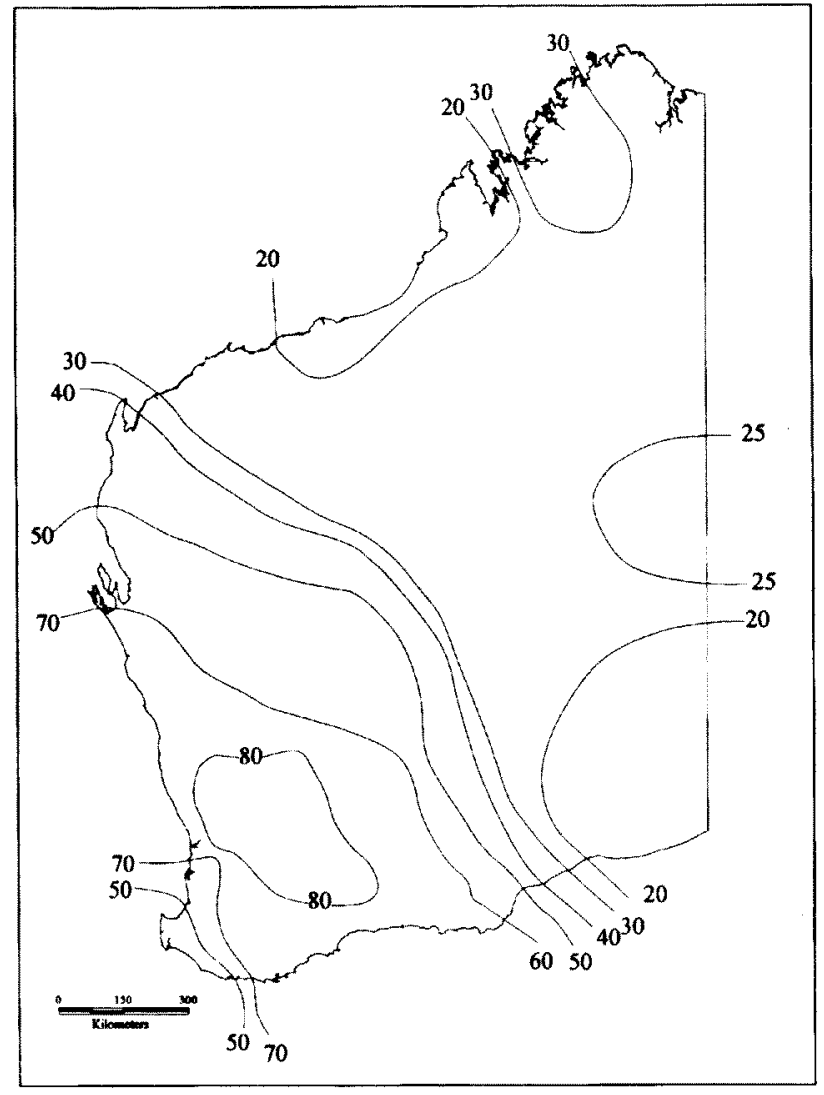

Figure 2 Species richness patterns of the native Asteraceae of Western Australia.

annuals (52 taxa) that are widespread in the winter rainfall areas of the semi-arid and arid zone. There are also 20 taxa of the temperate zone that end their ranges in the Basin (not necessarily in the study area, e.g. Brachycome iberidifolia, Chthonocephalus pseudevax and Cratystylis subspinescens) and 13 tropical taxa that are at their southern limits (e.g. Blumea tenella, Launaea sarmentosa, Pluchea rubelliflora and Streptoglossa bubakii). There is also a component of 12 taxa that are either endemics or species centred on the Basin (e.g. Chthonocephalus oldfieldianus, Haptotrichion colwillii, Rhodanthe cremea and Rhodanthe oppositifolia subsp. ornata). Many of these are recently described or still unnamed.

The pattern shown in the Asteraceae is repeated in the Poaceae (Keighery, 1984), Chenopodiaceae (Wilson, 1984), Amaranthaceae and Goodeniaceae (Carolin et al., 1992). The desert elements of the flora are largely of southern affinities rather than arid tropical, as would be found further north.

The other major influence is that the study area contains a portion of the northern heathlands of the South-West Botanical Province, a large section of desert to the north and east, and the interzone between them (Beard, 1990). The northern heathlands are diverse in members of the Proteaceae, especially Grevillea (Gibson et al. 1997), and the ericoid Myrtaceae, especially members of the genera Scholtzia, Baeckea and Pileanthus. There is also a considerable number of eucalypt and orchid taxa, especially on heavy soils in the Kalbarri area. The Haemodoraceae, Epacridaceae (Keighery, 1996) and the genus Acacia (Hopper and Maslin, 1978) are also species diverse on the Kalbarri sandplains.

\section{Weeds}

In total, 88 species of naturalised vascular plant species (weeds) were recorded for the area. These weeds are nearly all annuals from the families Poaceae (41 taxa), Asteraceae (19), Brassicaceae (12) and Caryophyllaceae (10). This is a low number compared to other areas of Western Australia (Keighery, 1995), where some 1032 taxa are recorded as naturalised (ca. 9\% of the total flora). But it is comparable to Cape Range, where 30 weeds were recorded by Keighery and Gibson (1993) and the Kimberley where 184 taxa have been recorded (Hussey et al., 1997). The largely intact nature of the native vegetation of the study area lowers the number of weeds. It is likely that further collecting around the townsites of Kalbarri and Carnarvon will increase the number of naturalised taxa, but it is considered that the major environmental weeds have been documented.

Certain weeds have already had a severe impact on parts of the study area. Foremost are riverine sites, especially along the Gascoyne, Wooramel and Irwin Rivers where the fringing understorey vegetation is often dominated by Buffel Grass (Cenchrus ciliaris), Mosman River Grass (Cenchrus setigerus) and Castor Oil Plants (Ricinus communis). Numerous herbaceous weeds such as Cape Weed (Arctotheca calendula) dominate the Murchison River foreshore in Kalbarri National Park, probably due to past grazing. The other major areas of weed invasion are under the Acacia shrublands of Zuytdorp and Cooloomia National Park where Brassica tournefortii has replaced Parietaria debilis, after sheep, rabbit and now goat grazing pressure. There are similar, but more localised problems in the Shark Bay World Heritage Area.

Several other weeds are potentially serious. Patterson's Curse (Echium plantagineum) is spreading along road verges through the southern arid zone, including North West Coastal Highway, and has the potential to replace the mass displays of everlastings in these areas. Alford et al. (2000) have reported Boxthorn (Lycium ferocissimum) on islands in the Shark Bay World Heritage area. This species is already a major pest on other offshore islands. Athel Pine (Tamarix aphylla), a serious weed of the Finke River system in the Northern Territory, is spreading along the Gascoyne River at Carnarvon. 


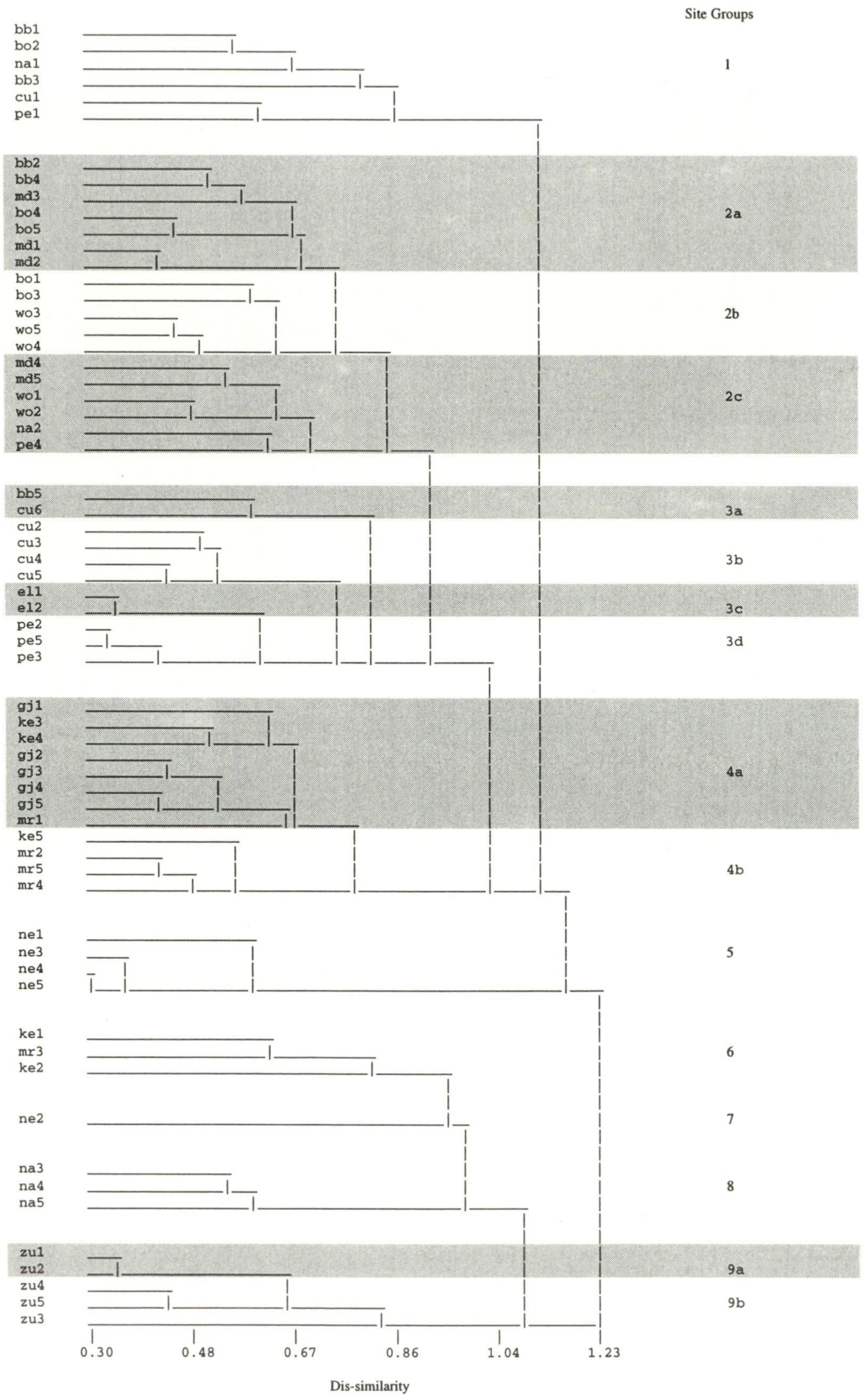

Figure 3 Dendrogram of the nine major site groups defined by the classification of the vascular flora. 
Table 1 Number of taxa recorded for the eight major reserves of the study area.

\begin{tabular}{lc}
\hline Reserve & Number of taxa \\
\hline Kalbarri National Park & 1071 \\
Toolonga Nature Reserve & 200 \\
Zuytdorp National Park & 314 \\
Cooloomia Nature Reserve & 226 \\
Francois Peron National Park & 279 \\
Bernier Island Nature Reserve & 59 \\
Dorre Island Nature Reserve & 143 \\
Kennedy Range National Park & 314 \\
\hline
\end{tabular}

\section{Reservation status of species}

There are eight major conservation reserves in this area (Figure 1). A major aspect of the present study was to attempt to produce an indication of the reservation status of individual plant taxa in the study area. Species lists for all eight major reserves were compiled. The flora of the numerous small island nature reserves in the Shark Bay World Heritage Area have been compiled separately (Alford et al., 2000; A.A. Burbidge pers. comm.). Total numbers of taxa recorded for the eight major reserves are shown in Table 1 with full lists in Appendix 1.

These parks and reserves contained a total of 1559 taxa leaving 574 taxa ( $37 \%$ of the total) that were not recorded for any conservation area (Appendix 1 ). These unreserved taxa were composed of six distinctive groups. They were:

- Marine angiosperms (Cymodocea, Halophila and Posidonia). These taxa are largely covered by marine reserves proposed for the World Heritage Area.

- Wetland taxa of tropical or arid affinities (e.g. Peplidium species, Potamogeton species, Schoenoplectus species, Cyperus difformis). These species occur in the northern sector of the study area, around Lake MacLeod, major rivers and in springs near the Kennedy Range.

- Terrestrial taxa of tropical affinities, especially those occurring on clay or alluvial soils that penetrate the study area in the north, usually along the major rivers or drainage lines (e.g. Crinum flaccidum) or on coastal limestones (Grevillea variifolia).

- Red sand taxa confined to the Acacia shrublands of the central region of the study area.

- Species confined to freshwater claypans (e.g. Lythrum sp. Towrana (Cranfield 2183) and Rumex crystallinus)

- Endemics of the World Heritage Area. There are 45 endemics of the Shark Bay World Heritage Area that are largely found on Tamala and Nanga Stations. Although these are not yet in a conservation reserve, current proposals regarding the property (Anonymous, 1997) will see nearly all of these placed in an expanded Zuytdorp Nature Reserve.

\section{Rare and Priority Flora:}

There are 11 species of declared rare flora and 144 taxa of priority flora recorded in the study area (Table 2; CALM, 1998). Of these priority taxa 33 are $P 1,62$ are P2, 39 are P3 and 10 are P4. (See Appendix 1 for definitions of conservation codes). Of the declared rare species, eight are confined to riverine cliffs or heavy soils in the Kalbarri area (Beyeria lepidopetala, Caladenia bryceana subsp. cracens, Caladenia wanosa, Drakaea concolor, Eremophila microtheca, Hypocalymma longifolium, Lechenaultia chlorantha and Leucopogon marginatus).

\section{New records and range ends}

Numerous new records and range extensions were noted during the survey. One notable example was the recording of Eremophila occidens $\mathrm{ms}$ at Nanga, this species having been previously regarded as endemic to Cape Range. Taxa endemic to all or part of the study area and taxa at their northern or southern limits in the study area are annotated in Appendix 1.

Most notable is the listing of 223 taxa at their northern limit in Kalbarri National Park, being over $20 \%$ of the Park's known flora. This is a comparable figure to another conservation area with numerous range ends, the Stirling Range. Another 229 taxa end their range within the World Heritage area to the north of Kalbarri (Trudgen and Keighery, 1995). This is further evidence that the area is a major transition zone for the vascular flora of Western Australia.

\section{Vegetation patterning}

A total of 626 taxa were recorded from the 63 sites (over $25 \%$ of the known flora of the study area). Of these 626 taxa, $218(35 \%)$ were recorded in only one site and were excluded because preliminary analysis of the total dataset indicated that these 'singletons' added little information. The final dataset included 408 taxa from 63 sites. Species richness varied from nine to 66 taxa per site (with singletons excluded), with individual taxa occurring in between two and 40 sites.

In this analysis site groups are partitioned at the nine group level (Figure 3 ) and species assemblages at the 20 group level (Table 3 ). Some site groups showed distinct pattern below this level and these were designated as subgroups. In all, 15 sites groups and subgroups were defined.

The major floristic boundary in the southwest of the study area is clearly evident in the analysis with site groups 1 to 6 representing typical Carnarvon vegetation types and site groups 8 and 9 


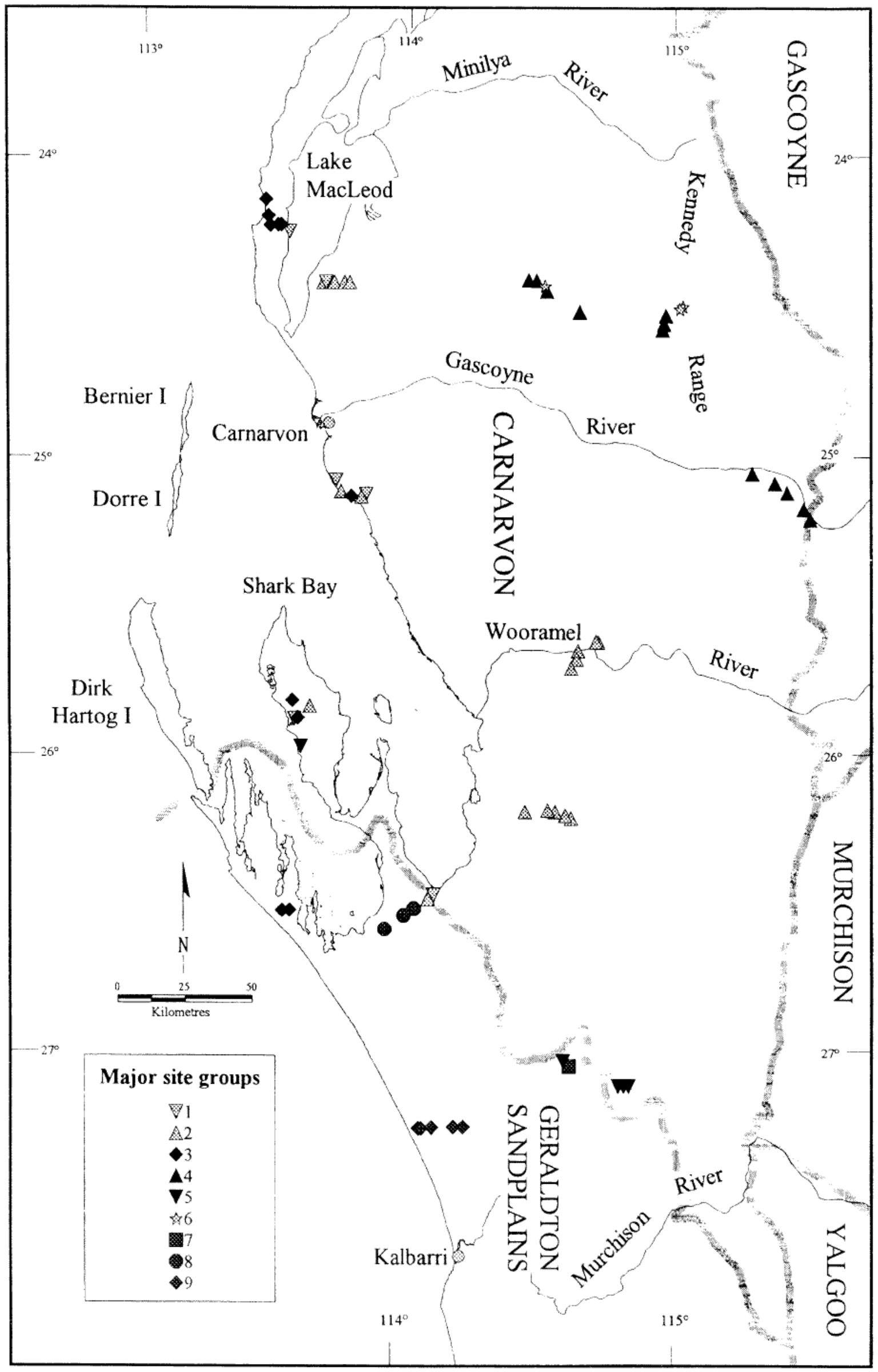

Figure 4 Distribution of the nine major site groups across the study area. 
Table 2 Rare and Priority Flora recorded for the study area. [ms indicates a manuscript name currently used by Western Australian Herbarium (PERTH); see Appendix 1 for definitions of conservation codes].

\begin{tabular}{lc}
\hline Taxon & Conservation \\
\hline Beyeria lepidopetala & $\mathrm{R}$ \\
Caladenia bryceana subsp. cracens ms & $\mathrm{R}$ \\
Caladenia hoffmanii ms & $\mathrm{R}$ \\
Caladenia wanosa & $\mathrm{R}$ \\
Drakaea concolor ms & $\mathrm{R}$ \\
Drakonorchis barbarella ms & $\mathrm{R}$ \\
Eremophila microtheca & $\mathrm{R}$ \\
Eucalyptus beardiana & $\mathrm{R}$ \\
Hypocalymma longifolium & $\mathrm{R}$ \\
Lechenaultia chlorantha & $\mathrm{R}$ \\
Leucopogon marginatus & $\mathrm{R}$
\end{tabular}

Beyeria gardneri

Chamelaucium oenanthum ms

Chthonocephalus oldfieldianus

Chthonocephalus spathulatus

Eremophila cuneata $\mathrm{ms}$

Eremophila lanata ms

Eremophila physocalyx ms

Labichea eremaea

Lepidium scandens

Levenhookia octomaculata

Macarthuria georgeana

Malleostemon sp. Hardabutt Rapids (D.Bellairs 1654A)

Millotia depauperata

Persoonia brachystylis

Persoonia papillosa

Pityrodia axillaris

Ptilotus beardii

Ptilotus stipitatus

Ptilotus stirlingii var. pumilus

Rhodanthe sp. Overlander (P.S.Short 2096)

Schoenia filifolia subsp. arenicola

Scholtzia cordata ms

Scholtzia sp. Eurardy (J.S.Beard 6886)

Scholtzia sp. Folly Hill (M.E.Trudgen 12097)

Scholtzia sp. Murchison River (A.S.George 7098)

Sclerolaena stylosa

Tetragonia coronata

Thryptomene ninghanensis $\mathrm{ms}$

Thryptomene sp. Carrarang (M.E.Trudgen 7420)

Thryptomene sp. Steep Point (M.E.Trudgen 7421)

Thryptomene sp. Tamala (M.E.Trudgen 7384)

Verticordia lepidophylla var. quantula

Vittadinia cervicularis var. oldfieldii

Abutilon sp. Hamelin (A.M.Ashby 2196)

Abutilon sp. Quobba (H.Demarz 3858)

Acacia gelasina

Acacia leptospermoides subsp. obovata

Acacia stereophylla var. cylindrata

Acacia subrigida

Acanthocarpus parviflorus

Angianthus microcephalus

Anthotroche myoporoides

Baeckea subcuneata

Bergia auriculata

Beyeria cygnorum

Calytrix drummondii

Calytrix formosa

Calytrix harvestiana
Taxon

Conservation Code

Calytrix paucicostata

Calytrix purpurea

Chamelaucium marchantii

Chthonocephalus muellerianus

Chthonocephalus tomentellus

Cryptandra glabriflora

Cryptandra scoparia var. microcephala

Dampiera krauseana

Eremaea acutifolia

Eremophila glabra subsp. psammophora ms

Eremophila occidens $\mathrm{ms}$

Eucalyptus diminuta $\mathrm{ms}$

Frankenia confusa

Grevillea annulifera

Grevillea costata

Grevillea rogersoniana

Grevillea stenomera

Grevillea triloba

Hemiandra sp. Kalbarri (D.Bellairs 1505)

Malleostemon sp. Cooloomia (S.D.Hopper 1353)

Malleostemon sp. Kalbarri (L.A.Craven 7083)

Malleostemon sp. Moonyoonooka (R.J.Cranfield 2947)

Melaleuca huegelii subsp. pristicensis

Microcorys tenuifolia

Millotia jacksonii

Murchisonia fragrans

Olearia occidentissima

Pityrodia glutinosa

Platysace sp. Kalbarri (D.\& B.Bellairs 1383)

Platysace sp. Kennedy (P.G.Wilson 8450 )

Ptilotus alexandri

Rhodanthe oppositifolia subsp. ornata

Rumex crystallinus

Scaevola chrysopogon

Schoenus sp. Kalbarri (K.R.Newbey 9352)

Scholtzia sp. East Yuna (A.C.Burns 6)

Scholtzia sp. Galena (W.E.Blackall 4728)

Scholtzia sp. Ross Graham Lookout (S.Maley 6)

Scholtzia sp. Z-Bend (Bellairs-Kalflora 912a)

Sondottia glabrata

Thryptomene sp. Eagle Gorge (A.G.Gunness 2360)

Thryptomene sp. Eurardy (D.\& B.Bellairs)

Thryptomene sp. Junga Dam (A.G.Gunness 2383A) 2

Thryptomene stenophylla

Thysanotus kalbarriensis ms

Verticordia dasystylis subsp. kalbarriensis

Verticordia galeata

2

2

Acacia didyma

Acacia drepanophylla

Acacia isoneura subsp. nimia ms

Acacia plautella ms

Acacia sclerosperma subsp. glaucescens

Anthocercis intricata

Anthotroche walcottii

Arnocrinum drummondii

Calocephalus aervoides

Calycopeplus marginatus

Centrolepis cephaloformis subsp. murrayi

Chamelaucium conostigmum ms

Comesperma acerosum

2

2

2

2

2

2

2 
Table 2 (cont.)

\begin{tabular}{llll}
\hline Taxon & Conservation Code & Taxon & Conservation Code \\
\hline Cryptandra nudiflora & 3 & Scaevola oldfieldii & 3 \\
Dicrastylis linearifolia & 3 & Scholtzia sp. Ajana (T.A.Halliday 137) & 3 \\
Eucalyptus foecunda subsp. Coolimba & & Stenanthemum divaricatum & 3 \\
$\quad$ (M.I.H.Brooker 9556) & 3 & Verticordia cooloomia & 3 \\
Geleznowia vernicosa & 3 & Verticordia densiflora var. roseostella & 3 \\
Goodenia sericostachya & 3 & Verticordia dichroma var. dichroma & 3 \\
Grevillea candicans & 3 & Verticordia dichroma var. syntoma & 3 \\
Grevillea leptopoda & 3 & Villarsia congestiflora & 3 \\
Grevillea stenostachya & 3 & & \\
Gymnanthera cunninghamii & 3 & Calothammus pachystachyus & 4 \\
Hemigenia pimelifolia & 3 & Diuris recurva & 4 \\
Lasiopetalum oldfieldii subsp. oldfieldii & 3 & Goodenia neogoodenia & 4 \\
Lasiopetalum oppositifolium & 3 & Jacksonia velutina & 4 \\
Lepidobolus densus ms & 3 & Lepidium puberulum & 4 \\
Macarthuria intricata & 3 & Lepidosperma rupestre & 4 \\
Mirbelia sp. Kalbarri (M.D.Crisp 6261) & 3 & Plectrachne bromoides & 4 \\
Petrophile biternata & 3 & Verticordia capillaris & 4 \\
Physopsis chrysophylla & 3 & Verticordia polytricha & 4 \\
Phlegmatospermum drummondii & 3 & Wurmbea murchisoniana & 4 \\
\end{tabular}

representing typical Irwin (Geraldton Sandplains) vegetation types (Figures 3 and 4). Site group 7 is represented by only a single site and its affinities are not clear. Site groups 1 to 4 were the most widespread across the study area.

Site group 1 comprised the sites with a major saline influence. Species assemblage $O$ is highly faithful (i.e. largely restricted) to this site group with low to moderate levels of constancy (referring to the degree of occurrence of a species assemblage in the site group). Species in this assemblage include Halosarcia indica and $H$. halocnemoides (samphire species), Frankenia aff. pauciflora (a species generally restricted to saline calcareous substrates) and a series of annual taxa which are restricted to this site group. This group encompasses a range of saline plots ranging from Halosarcia and Sclerostegia shrublands to an Atriplex shrubland upslope from a saline flat. Sites occurred in coastal areas from Nanga to Lake MacLeod (Figure 4) and species richness averaged 23.7 taxa/ plot.

Acacia shrublands are one of the most widespread and typical communities of the Carnarvon Bioregion. Site groups 2 and 4 represent the Acacia shrublands on red sands. No single Acacia species dominated sites in site group 2 but Acacia sclerosperma and $A$. linophylla were the most common; sites in site group 4 were generally dominated by Acacia aneura (Mulga). Site group 2 was a very widespread group in the centre of the study area, stretching from Nanga to Boolathana and east to Meedo (Figure 4). It had the highest average species richness of 46.6 taxa / plot.

While most sites in site group 2 were dominated by Acacia spp., one site along the Wooramel River
(MD3) had an overstorey of Eucalyptus victrix while the understorey was typical of the Acacia shrublands. Another site (BO1) was dominated by Atriplex, it differed from sites in site group 1 in being rich in species belonging to assemblage $K$ (especially in terms of herbs), an assemblage largely lacking in the site group 1 . This site was classified most similar to BO3 (a typical Acacia shrubland).

Species assemblage A was moderately faithful to both site group 2 and site group 4, while species assemblages D, E, and J differentiated site group 2 from other site groups. Species assemblage $G$ was largely confined to site groups $1,2 \mathrm{a}$ and $2 \mathrm{~b}$, species assemblage I was largely restricted to site group $2 a$ and site group 6 and species assemblage $L$ was most faithful to site group $2 c$ and site group 5 .

The different subgroups within site group 2 reflected differences in Acacia species found on these sites. Acacia tetragonophylla was the most widespread Acacia occurring in all three subgroups, A. linophylla was largely restricted to subgroups $2 \mathrm{a}$ and $2 \mathrm{~b}$ as was $A$. victoriae while $A$. grasbyi was restricted to site group $2 \mathrm{~b}$ and $A$. coolgardiensis subsp. effusa was largely restricted to subgroup $2 \mathrm{c}$ and site group 5 (Table 3 ). Weedy annuals such as ${ }^{*}$ Hypochaeris glabra, ${ }^{*}$ Bromus arenarius, ${ }^{*}$ Cenchrus ciliata, ${ }^{*}$ Sonchus oleraceus and *Asphodelus fistulosa are more common in subgroups $2 a$ and $2 b$ compared to $2 \mathrm{c}$.

The coastal Acacia and Melaletica shrublands of site group 3 are largely defined by species assemblages $Q$ and $R$ which are highly faithful to site group 3 but with generally only low to moderate consistency. Site group 3 as a whole has a coastal distribution extending from Edel Land to Cuvier; average species richness is high at 45.6 taxa 


\section{Species Assemblage A}

abutilon otocarpum

Phyllanthus maderaspatensis

Bulbostylis barbata

Calandrinia sp. (GJK/NG 1495)

Cassia helmsii

Eremophila subfloccosa

Maireana planifolia

Asphodelus fistulosus

Chenopodium cristatum

Chthonocephalus spathulatus

Rhodanthe charsleyae

Stenopetalum pedicellare

Acacia linophylla

Spartothamnella teucrififlora

Myriocephalus guerinae

Acacia victoriae

Tragus australianus

Sclerolaena densiflora

Boerhavia gardneri

Hakea preissi

Corchorus walcottil

Eragrostis dielsii

Ptilotus villosiflorus

Triraphis mollis

Eriachne aristidea

Acacia aneura

Eriachne pulchella

ptilotus helipteroides

Tribulus astrocarpus

Tripogon loliiformis

Paspalidium basicladum

Goodenia havilandi

Enneapogon caerulescens

Haloragis trigonocarpa

Ptilotus aervoides

Stenopetalum sphaerocarpum

Cleome viscosa

Lepidium oxytrichum

Eriachne helmsii

\section{site Groups}

$4 \mathbf{b}$

5

$9 b$

bbnbcp $\mid$ bbmbbmm $\mid$ bbwww $\mid$ mmwwnp $\mid$ bc $\mid$ cccc lee ppp /gkkggggm $\mid$ kmmm $|\mathrm{nnnn}| \mathrm{kmk}|\mathrm{n}| \mathrm{nnn}|\mathbf{z z}| \mathbf{z z z}$ boabue bbdoodd 100000 ddooae bu uuuu 11 eee jeejjjjr errr eeee ere el aaa uu uuu

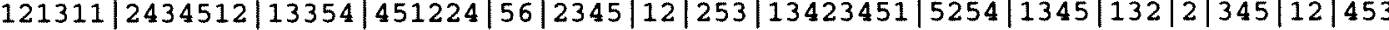

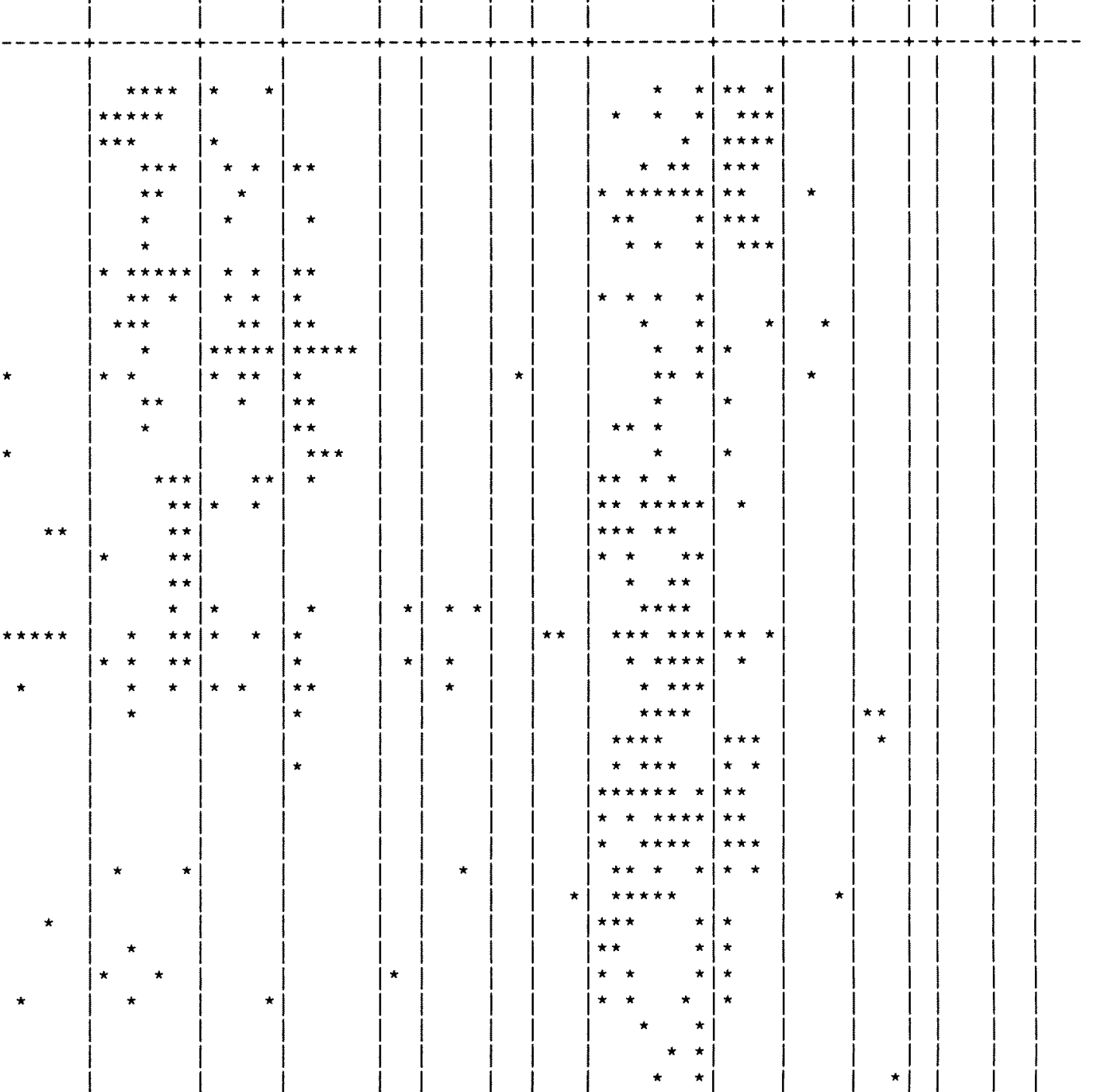


Species Assemblage

Eriachne avenacea

waitzia acuminata

Thyridolepis mitchelliana

Eremophila setacea ms

plectrachne rigidissima

Sida rohlenae

Hibiscus coatesii

\section{Species Assemblage C}

Acacia xiphophylla

Ptilotus exaltatus

Cassia sturti

Ptilotus polakij

Streptogiossa liatroides

Panicum effusum

plectrachne schinzii

Sauropus crassifolius

Sida corrugata

Atriplex lindleyi subsp. inflata

Marsdenia viridiflora

Sida aff. intricata (GJK/NG 1134)

Yakirra australiensis

\section{Species Assemblage}

Acacia grasbyi

Sarcostemma viminale

Cassia sp.

Zygophyl lum ovatum

Atriplex semilunaris

sisymbrium irio

Thysanotus speckii

Species Assemblage $E$

Brachyscome ciliaris

Podolepis capillaris

Tetragonia cristata

Enteropogon acicularis

Eremophila latrobei

Maireana carnosa

Eremophila clarkei

Hibiscus burtoni

Eremophila leucophylla

Ptilotus grandiflorus

Gyrostemon ramulosus

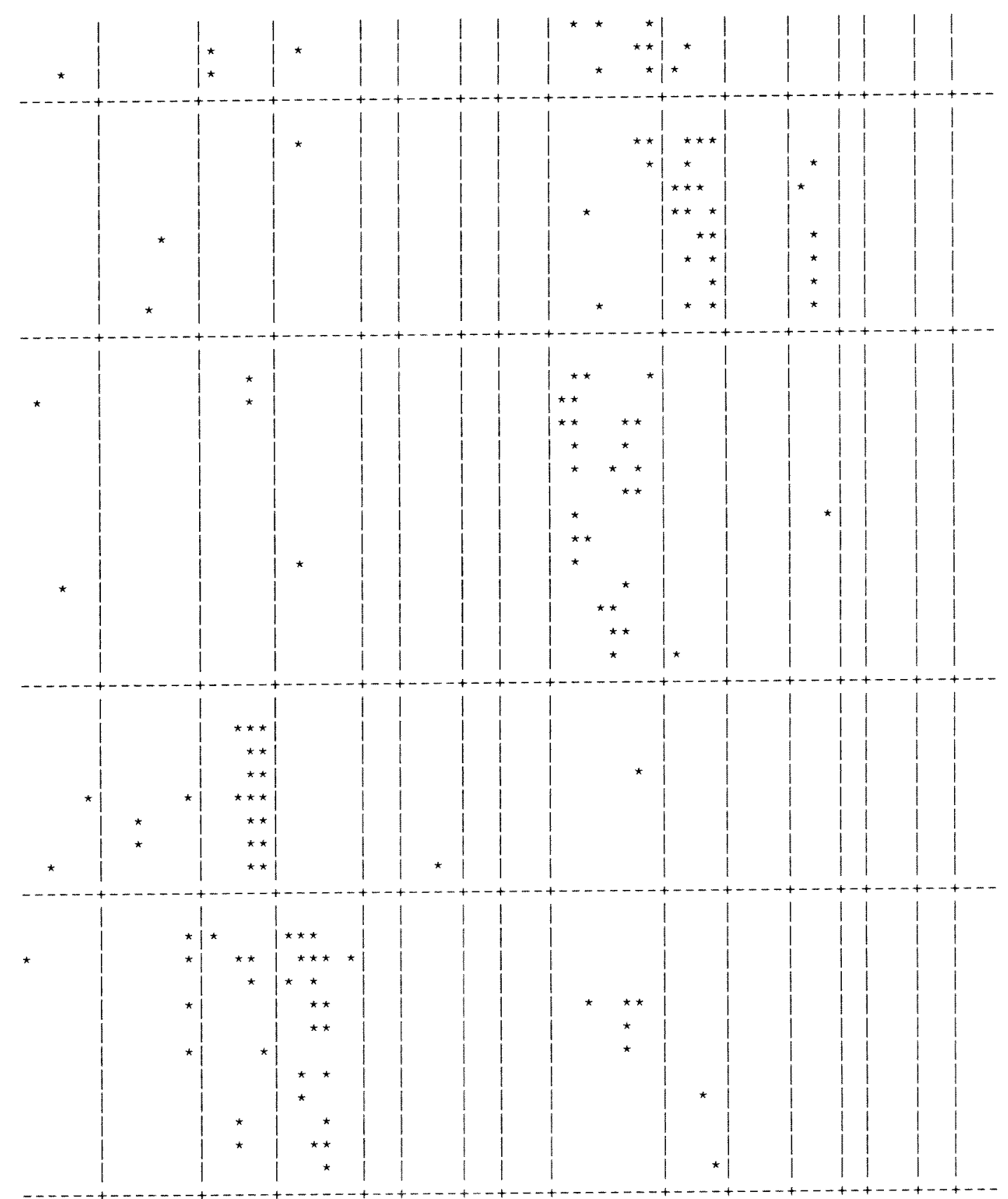


Species Assemblage $\mathbf{F}$

Acanthocarpus verticillatus

Glycine canescens

Gymnema granitica ms

Angianthus tomentosus

Lawrencia spicata

Maireana georgei

zygophyllum kochii

Chorizema racemosum

Eriachne benthamii

Calandrinia eremaea

Calandrinia liniflora

Lepidium linifolium

Species Assemblage $G$

Amaranthus mitchellii

Commicarpus australis

Portulaca oleracea

Trianthema triquetra

Maireana tomentosa

Atriplex vesicaria

Swainsona pterostylis

Calotis multicaulis

Cephalipterum drummondi

Sclerolaena recurvicuspis

Senecio glossanthus

Maireana trichoptera

Pogonolepis muelleriana

Convolvulus erubescens

Heliotropium undulatum

Hypochaeris glabra

Lotus cruentus

Rhodanthe psammophila

Rhodanthe chlorocephala

Tribulus forrestii

Dactyloctenium radulans

Eragrostis basedowi i

Tribulus terrestris

Lawrencia densiflora

Wahlenbergia tumidifructa
Site Groups

$\begin{array}{lllllll}4 b & 5 & 6 & 7 & 8 & 9 a & 9 b\end{array}$

$2 b \quad 2 c$

$3 b \quad 3 c \quad 3 d$

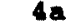

bbnbcp $\mid$ bbmbbmm $\mid$ bbwww $\mid$ mmwwnp $\mid$ bc $|c c c c|$ ee $\mid$ ppp $\mid$ gkkggggm $\mid$ kmmm $\mid$ nnnn $\mid$ kmk $|\mathrm{n}| \mathrm{nnn}|\mathrm{zz}| \mathrm{zzz}$

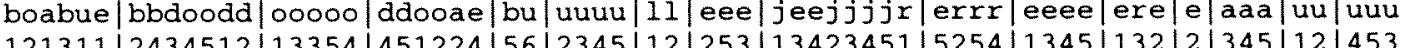
$121311|2434512| 13354|451224| 56|2345| 12|253| 13423451|5254| 1345|132| 2|345| 12|453|$

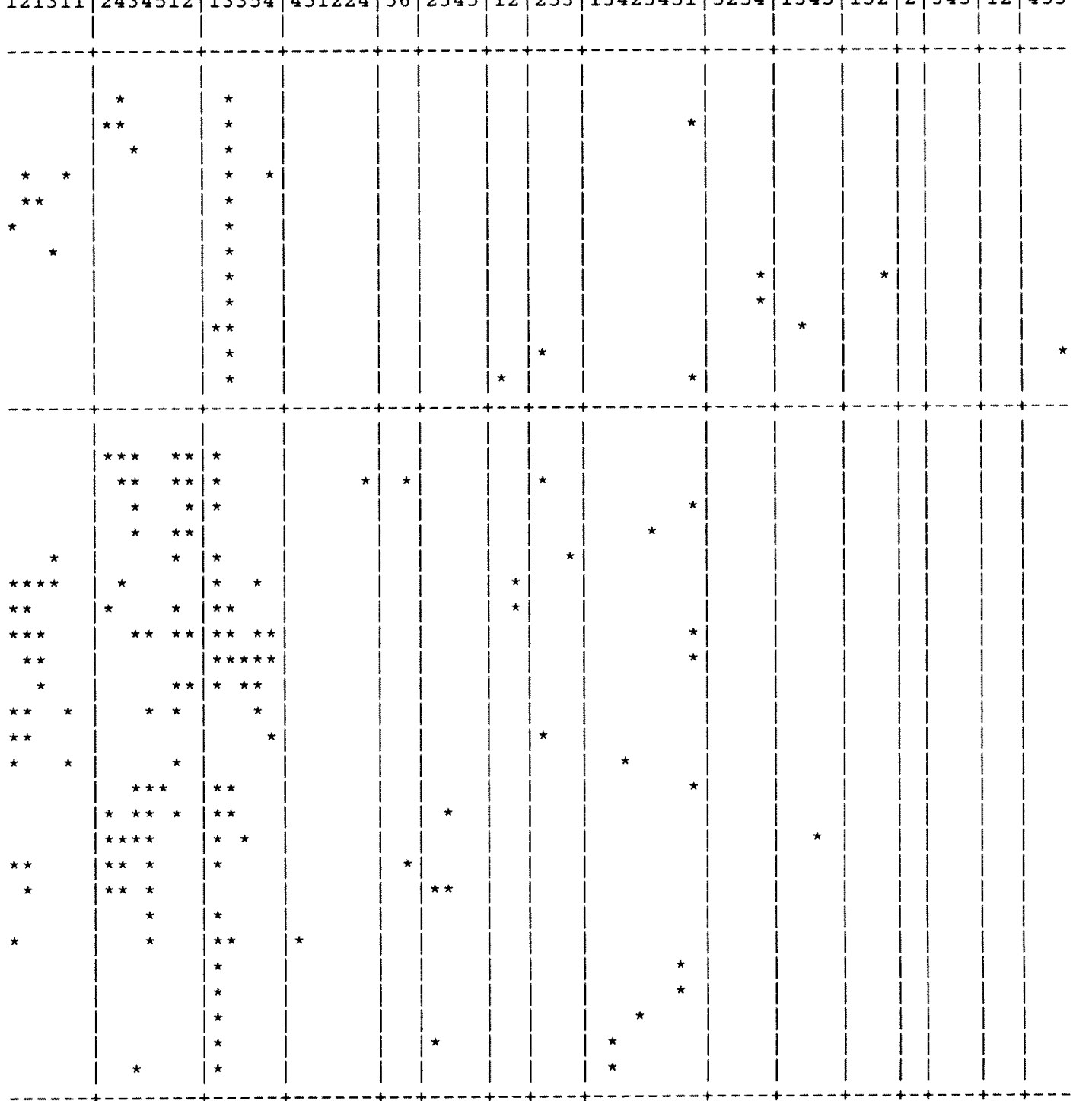


Emex australis

Sisymbrium erysimoides

Lotus australis

\section{Species Assemblage I}

\section{Acacia murrayana}

Pityrodia paniculata

Adriana tomentosa

Trichodesma zeylanicum

Anthobolus foveolatus

Indigofera occidentalis ms

Acacia ramulosa

Alectia ramulosa

Corynotheca pungens

Psammagrostis wiseana

Pityrodia loxocarpa

Tephrosia gardneri (GJK/NG 1074)

Eremophila crenulata ms

Tribulus cistoides

ms

Rhodanthe citrina

Goodenia tenuiloba

Rhagodia drummondii

Species Assemblage J

Calotis hispidula

Solanum cleistogamum

Exocarpos sparteus

Lobelia winfridae

Leichardtia australis

Rhagodia eremaea

Senecio gregorii

Jasminum calcarium

\section{Species Assemblage $\mathrm{K}$}

Abutilon oxycarpum

Euphorbia australis

Heterodendrum oleifolium

Cassia chatelainiana

Lobelia heterophylla

Acacia sclerosperma

Cenchrus ciliaris

Acacia tetragonophylla

Enchylaena tomentosa

Euphorbia boophthona

Paractaenum novae-hollandiae

Chenopodium gaudichaudianum

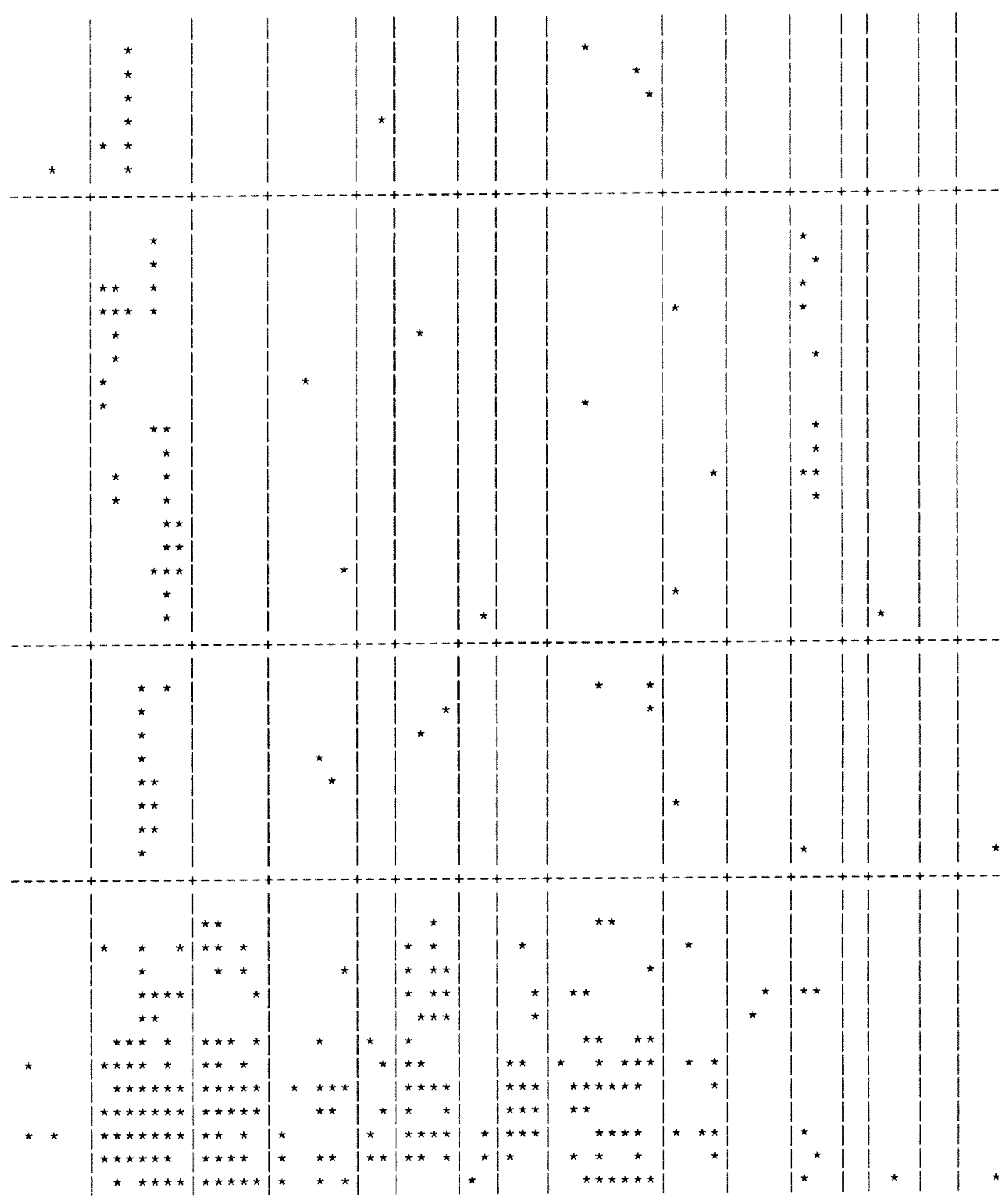


Tetragonia diptera Aristida holathera Ptilotus polystachyus Euphorbia drummondii Solanum lasiophyllum Murchisonia volubilis Eragrostis lanipes Brachyscome cheilocarpa Triglochin calcitrapum Brachyscome iberidifoli Calandrinia polyandra Erodium cygnorum

Pimelea microcephala Crassula colorata Ptilotus gaudichaudii Ptilotus obovatus Sida calyxhymenia Rhagodia latifolia Stylobasium spathulatum Strlobasium spathulatum Brachyscome latisquamea Sclerolaena diacantha Brassica tourneforti Threlkeldia diffusa Ptilotus divaricatus Rhagodia preissii

Nicotiana occidentalis

Rostraria pumila

Sonchus oleraceus

Scaevola spinescens

Scaevola tomentosa

zygophyllum fruticulosum

Cuscuta epithymum

Lepidium rotundum

Salsola kali

Dysphania rhadinostachya

Goodenia berardiana

Gnephosis arachnoidea

Parietaria debilis

\section{Species Assemblage L}

Acacia coolgardiensis subsp. effusa

Site Groups

3c 3a

2b

2c

4a

$\begin{array}{lllll}6 & 7 & 8 & 9 a & 9 b\end{array}$

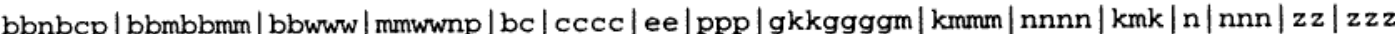
bo \begin{tabular}{l|l|l|l|l|l|l|l|l|} 
&
\end{tabular}

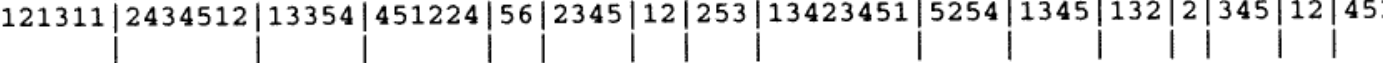

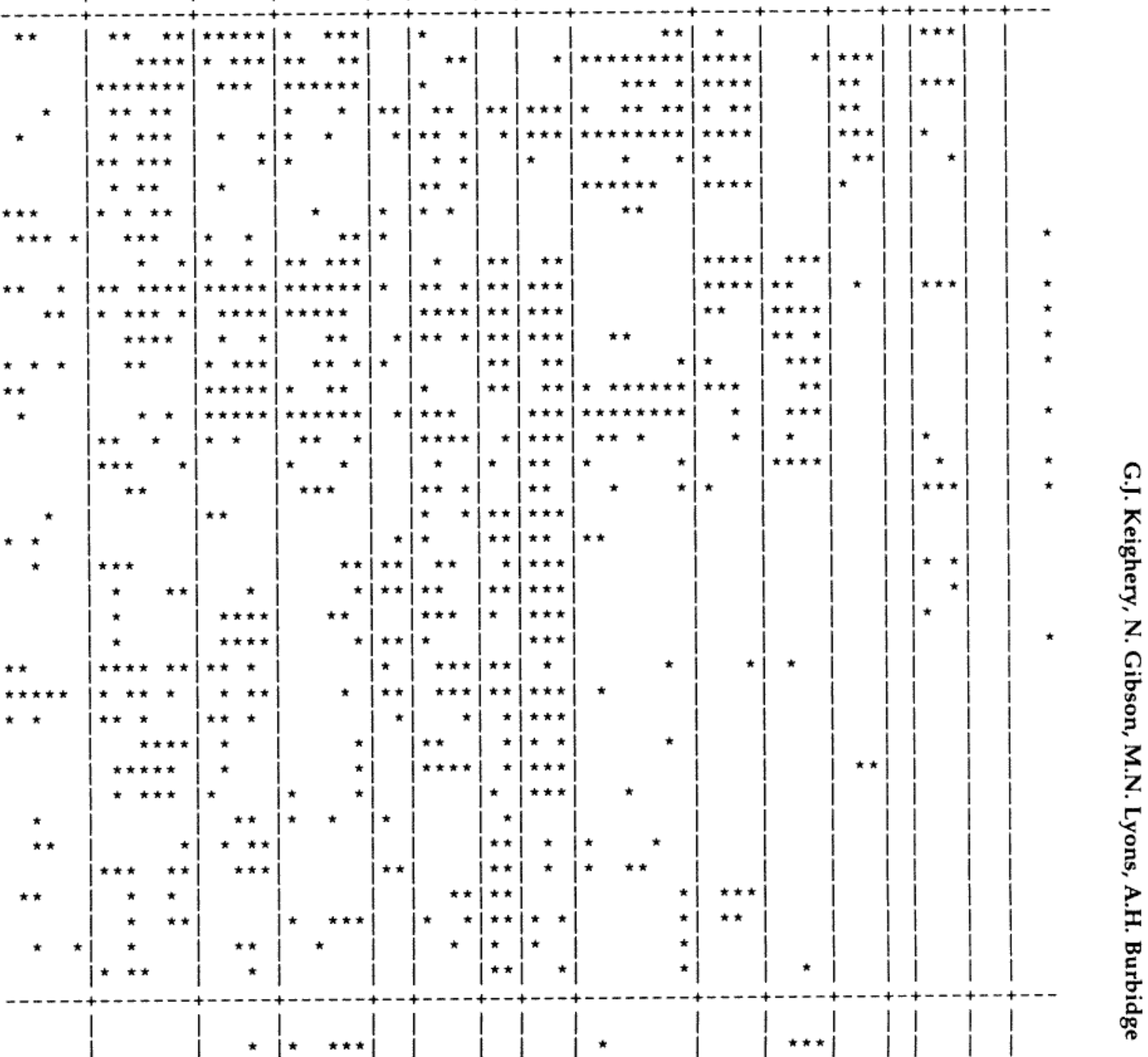


Waitzia nitida

Chthonocephalus tomentellus

Eremophila maitlandii

Porana sericea

Rhyncharrhena linearis

Podolepis canescens

Actinobole uliginosum

Solanum orbiculatum

Chthonocephalus pseudevax

Marsdenia australis

Dianella revoluta

Stipa elegantissima

\section{Species Assemblage M}

Acanthocarpus aff. robustus (Hopper 1367)

Thysanotus patersonii

Mirbelia ramulosa

Melaleuca sp. (Beard 6768)

Plectrachne bromoides

Acanthocarpus robustus

Loxocarya aspera ms

\section{Species Assemblage $N$}

Acacia latipes

Lechenaultia Iinarioides

Acacia subrigida

Lasiopetalum oppositifolium

Melaleuca aff. quadrifidus

Eremophila occidens ms

wurmbea cernua

Pityrodia verbascina

Acacia longispinea

Tricoryne aff. corynothecoides (GJK/NG 1274)

Eucalyptus eudesmioides

Lamarchea hakeifolia var. brevifolia

Stenanthemum complicatum

Baeckea sp. (A.S.George 11346)

Brachychiton gregorii

Grevillea stenobotrya

Verticordia forrestii

Allocasuarina acutivalvis

Grevillea eriostachya

Acacia spathulifolia

Calothamnus borealis

Halgania cyanea

Alyxia buxifolia

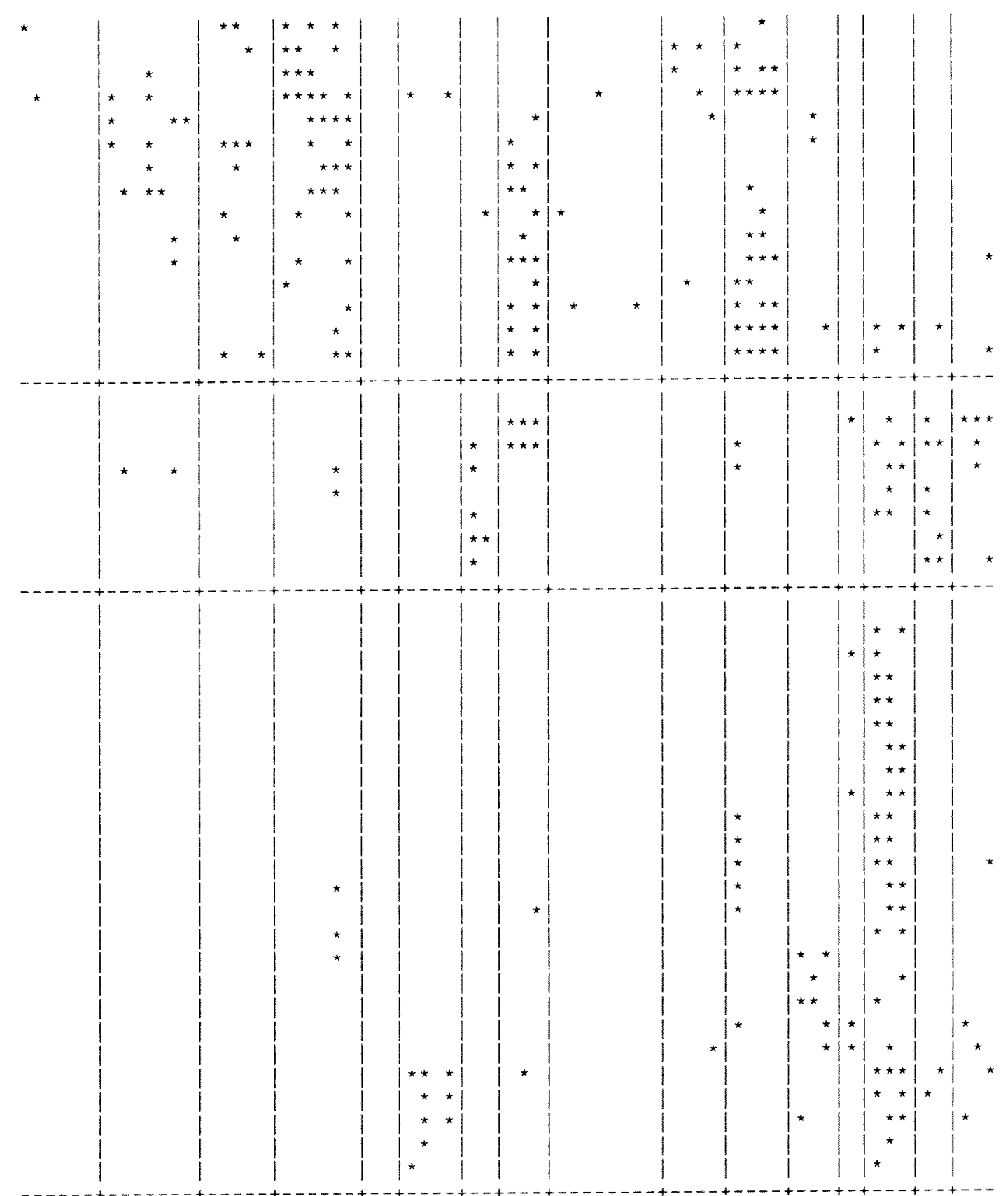


Species Assemblage O

Carpobrotus sp. (GJK/NG 1707)

Rhodanthe stricta

Frankenia aff. pauciflora

Triglochin centrocarpum

Tragrostis pergracilis

Gunniopsis septifraga

awrencia viridigrisea

Podolepis gardneri

zygophyllum compressum

Halosarcia indica

Halosarcia halocnemoides

Swainsona kingii

Sondottia glabrat

Didymanthus roe

Sclerolaena eurotioides

\section{Species Assemblage P}

Acacia roycei

Eucalyptus mannensis

Calandrinia corrigioloides

Bursaria occidentalis

Thysanotus manglesianus

Calandrinia lehmannii

Leucochrysum fitzgibbonii

Wurmbea densiflora

Callitris glaucophylla

Gilberta tenuifoli

Lysiana casuarinae

Trachymene ornata

Trachillea paradoxa

plantago aff. hispidula

Centrolepis drummondiana

Comesperma integerrimum

Gnephosis eriocephala

Poranthera microphylla

Goodenia occidentalis

Trachymene cyanopetala

Eremophila oldfieldii

Ptilotus stirlingi

Site Groups

3b 3c 3d

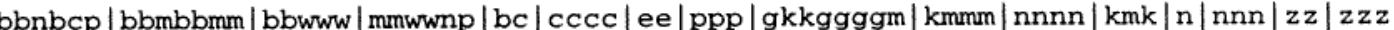

$4 b$

5

$\begin{array}{lllll}6 & 7 & 8 & 9 a & 9 b\end{array}$

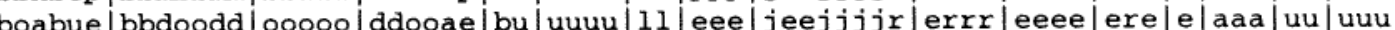
$121311|2434512| 13354|451224| 56|2345| 12|253| 13423451|5254| 1345|132| 2|345| 12 \mid 453$

***


Synaptantha tillaeacea

Gnephosis tenuissima

\section{species Assemblage 0}

\section{Acacia chartacea}

Diplopeltis intermedi

Goodenia triodiophila

Scaevola thesioides

Acacia coriacea subsp. coriacea

Haloragis gossei

Triodia pungens

Daviesia hakeoides

Brachysema macrocarpum

Scaevola sericophylla

Triodia basedowi

Dampiera incana

Hibiscus sturtii

Indigofera brevidens

zygophyl Ium eremaeum

Stipa nitida

learia dampieri subsp. dampieri ms

Stackhousia muricata

\section{Species Assemblage $R$}

Acacia ligulata

Trichanthodium skirrophorum

Beyeria cinerea

Eragrostis barrelieri

Erodium cicutarium

Triodia plurinervata

Urospermum picroides

Eremophila glabra

Wurmbea inframediana

Lepidium puberulum

Olearia aff. axillaris (GJK/NG 1025)

Poa drummondiana

Triglochin trichophorum

Podotheca gnaphalioides

Exocarpos aphyllus

Melaleuca cardiophylla

podotheca angustifolia

Thryptomene baeckeacea

Stipa crinita

Waitzia suaveolen.

olearia axillaris

Trachymene elachocarpa

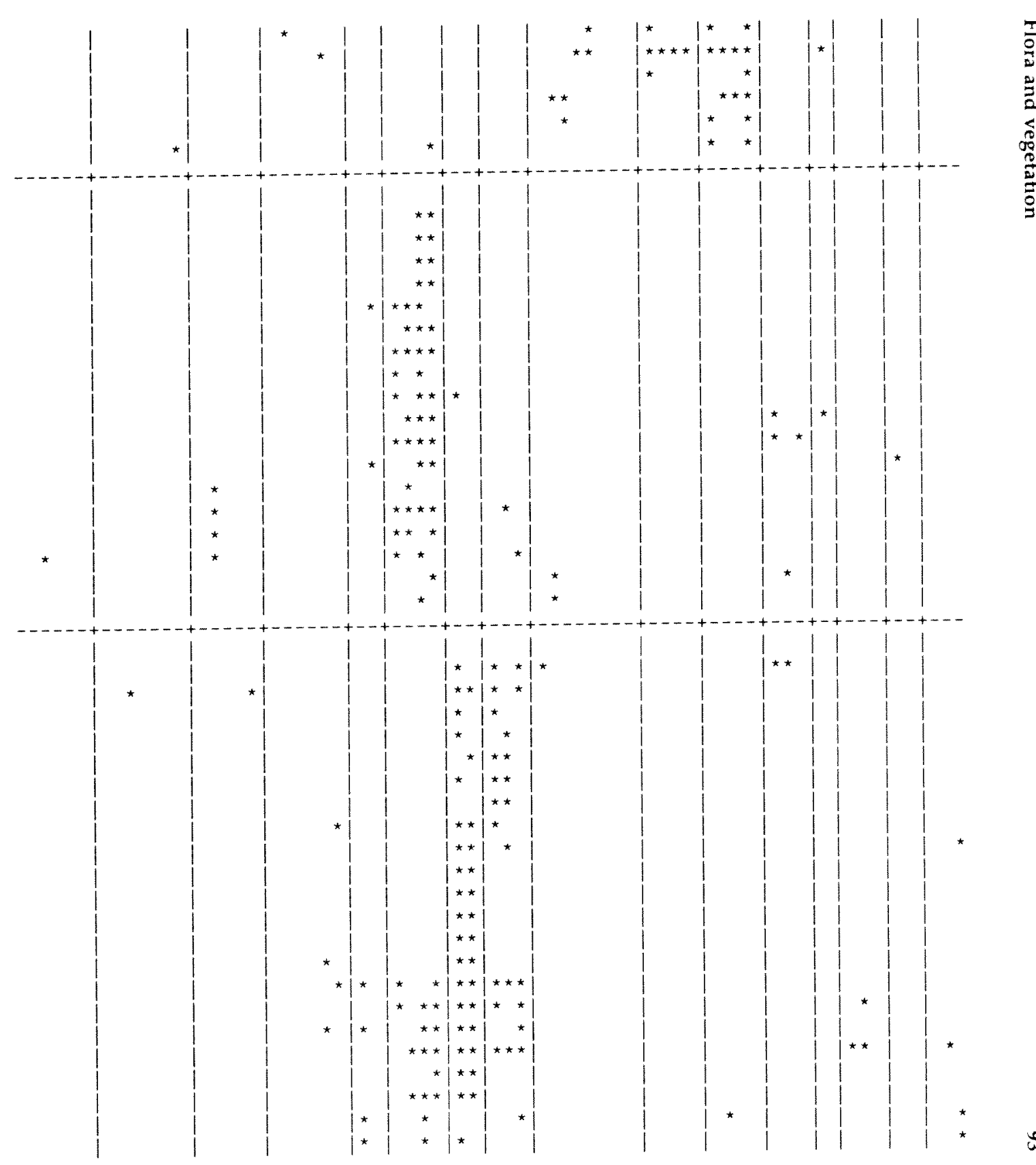


Atriplex cinerea

Scaevola crassifolia

Frankenia pauciflora

Rhodanthe humboldtiana

zygophyllum ammophilum

Atriplex paludosa subsp. moquiniana

Senecio lautus

Cyperus bulbosus

Millotia myosotidifolia

Bromus arenarius

Daucus glochidiatus

Cryptandra leuophracta

Danthonia caespitosa

Solanum oldfieldii

Dysphania plantaginella

\section{Species Assemblage s}

\section{Acacia blakelyi}

Actinostrobus arenarius

Allocasuarina campestris

Calytrix strigosa

Leucopogon cucullatus

Lyperanthus nigricans

Tetraria microcarpa

Thryptomene denticulata

Acacia cavealis ms

Drosera stolonifera subsp. stolonifera

Boronia coerulescens

Brachysema aphyllum

Monotaxis lurida

Petrophile semifurcata

Scaevola canescens

Calothamnus blepharospermus

Eremaea ebracteata

Stylidium macrocarpum

Stylidium repens

Leucopogon cordifolius

Lysinema ciliatum

Neurachne alopecuroidea

Petrophile brevifolia
Site Groups

$2 \mathbf{b}$

$2 c$

$3 b \quad 3 c \quad 3 d$

$4 a$

4b

5

678

$9 b$

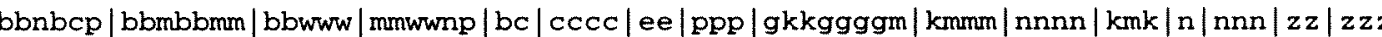

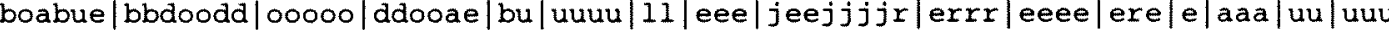

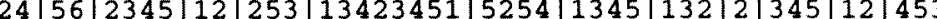

| |

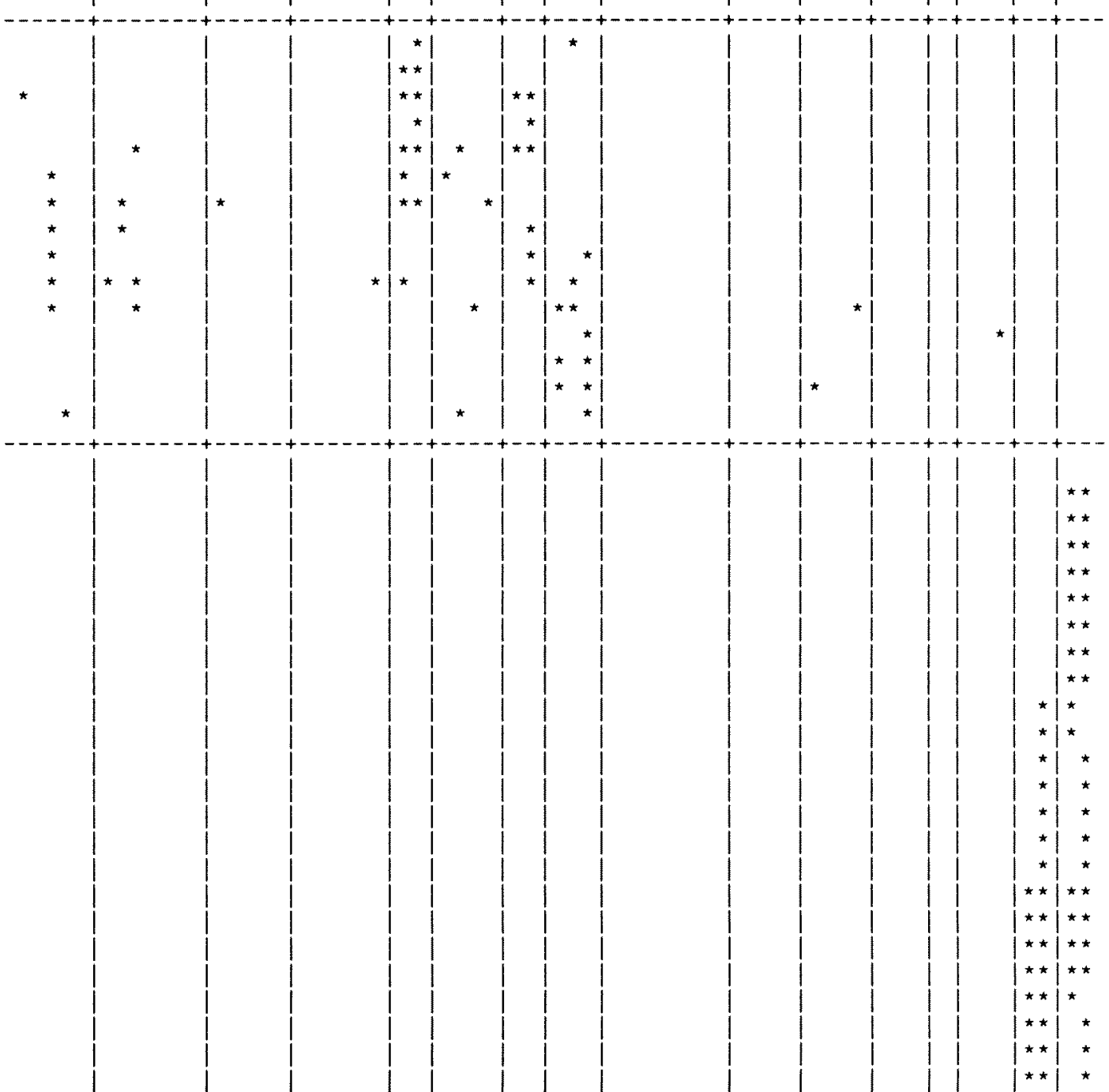


Schoenus clandestinus

Melaleuca conothamnoides

Melaleuca scabra

Mesomelaena preissii

opercularia spermacocea

Conospermum microflorum ms

Lepidobolus preissianus

Phymatocarpus porphyrocephalus

Drosera stolonifera subsp. humilis

Malleostemon sp Cooloomia (Hopper 1353)

Mesomelaena pseudostygia

Hibbertia racemosa

Hibbertia subvaginata

Melaleuca acerosa

Conostylis stylidioides

Hibbertia pungen.

Melaleuca aff. leiopyxis (GJK/NG 1708)

Ecdeiocolea monostachya

Hibbertia conspicua

Persoonia acicularis

Banksia ashbyi

Banksia sceptrum

Geleznowia verrucosa

Calytrix brevifolia

Grevillea annulifera

Plectrachne danthonioides

Scholtzia sp. Folly Hill (ME Trudgen 12097)

Cassytha aurea

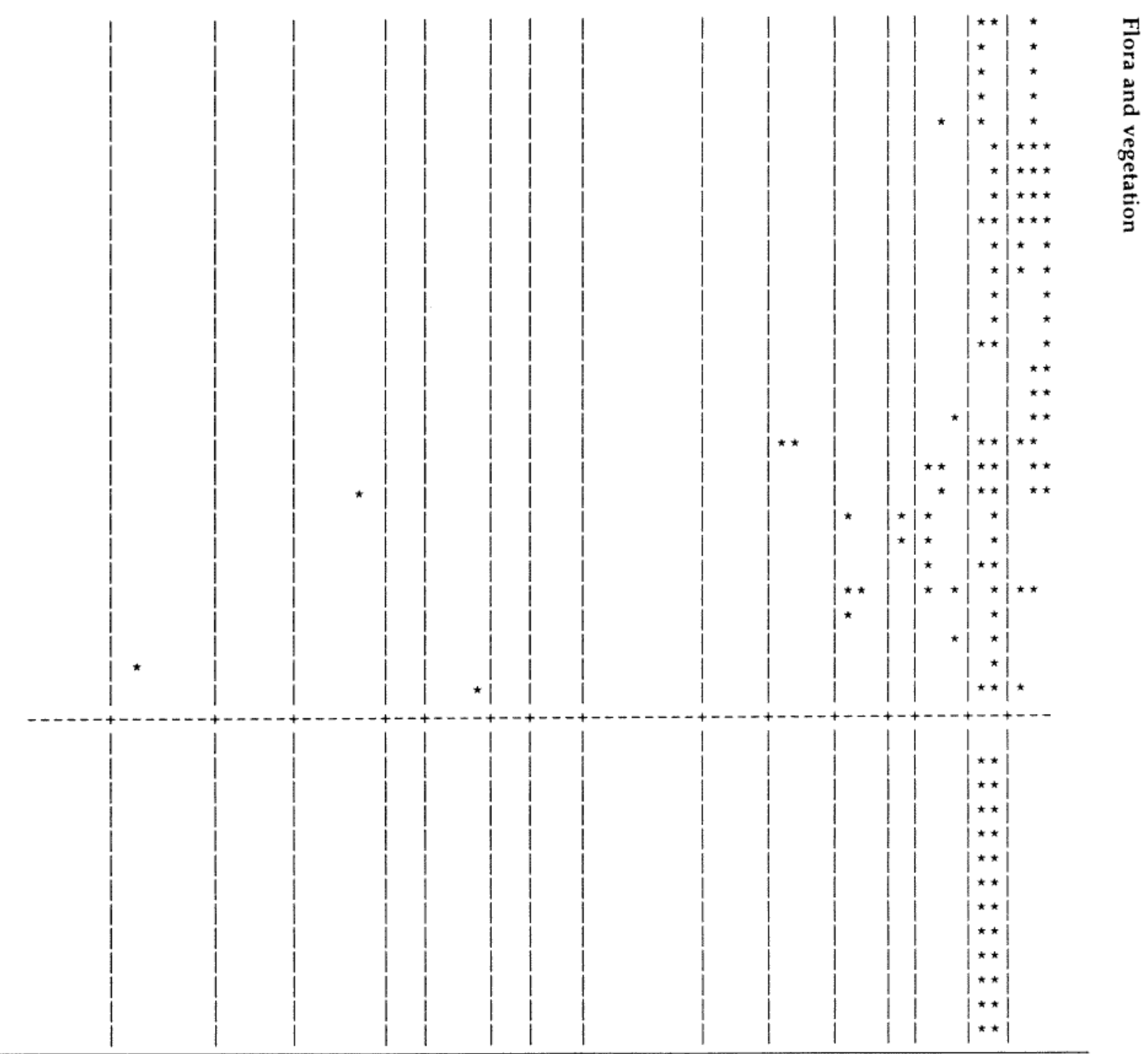

Species Assemblage T

Amphipogon turbinatus

Boronia purdieana

Cassytha racemosa

Conostylis aculeata

Dryandra borealis subsp. borealis

Gompholobium tomentosum

Grevillea preissii ms

Hibbertia spicata subsp. spicata

Patersonia occidentalis

Pimelea leucantha

Pityrodia oldfieldi

Stylidium elongatum 
Figure 5 Differences in predicted climatic parameters between the nine site groups defined by the vascular flora. ( $\mathrm{L}=$ lowest value, $\mathrm{U}=$ highest value, $\mathrm{I}=$ first quartile, $\mathrm{M}=$ mean, $\mathrm{D}=$ median).

Mean annual temperature $\left({ }^{\circ} \mathrm{C}\right):($ Kruskal-Wallis $=49.9$, df $=8, p<0.0001)$

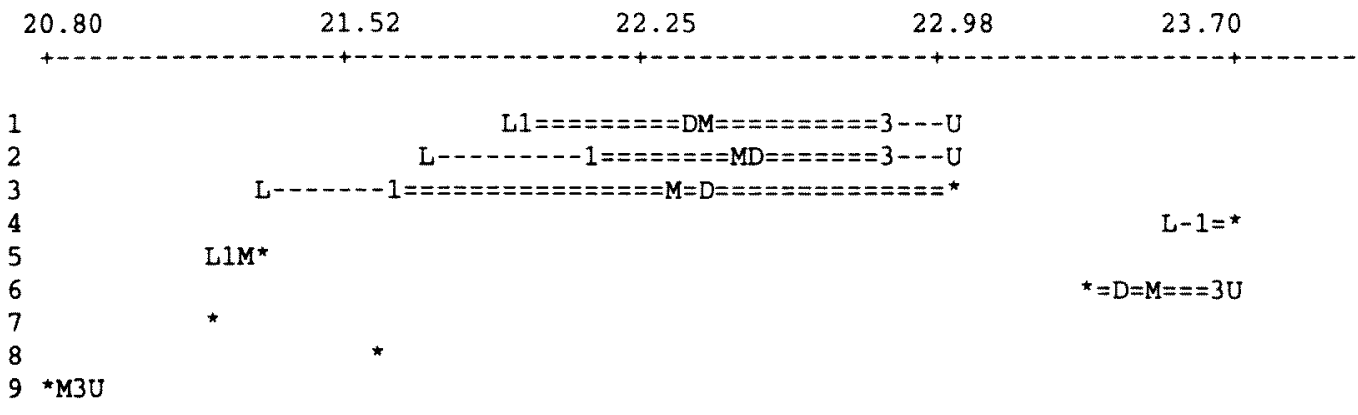

Diurnal temperature range $\left({ }^{\circ} \mathrm{C}\right):($ Kruskal-Wallis $=37.5$, df $=8, \mathrm{p}<0.0001)$

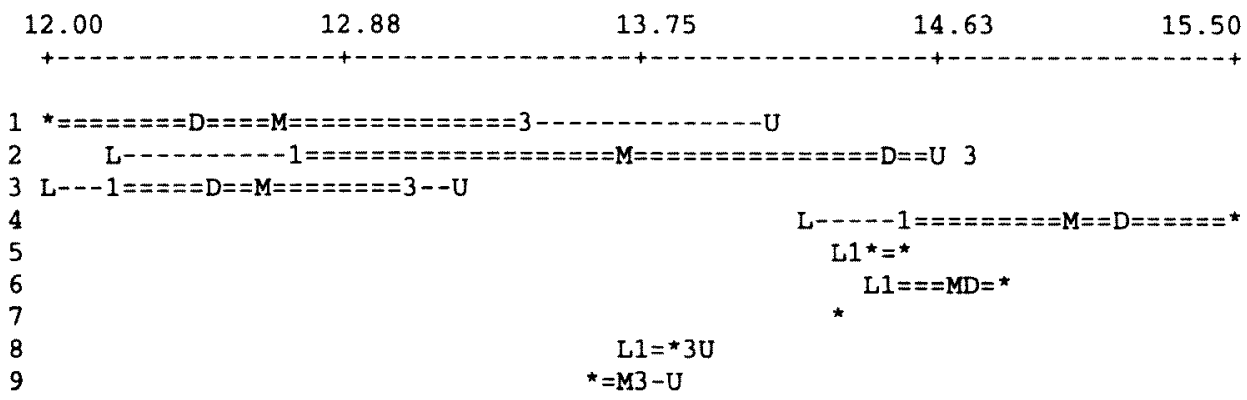

Annual temperature range $\left({ }^{\circ} \mathrm{C}\right):($ Kruskal-Wallis $=38.3$, df $=8, p<0.0001$ )

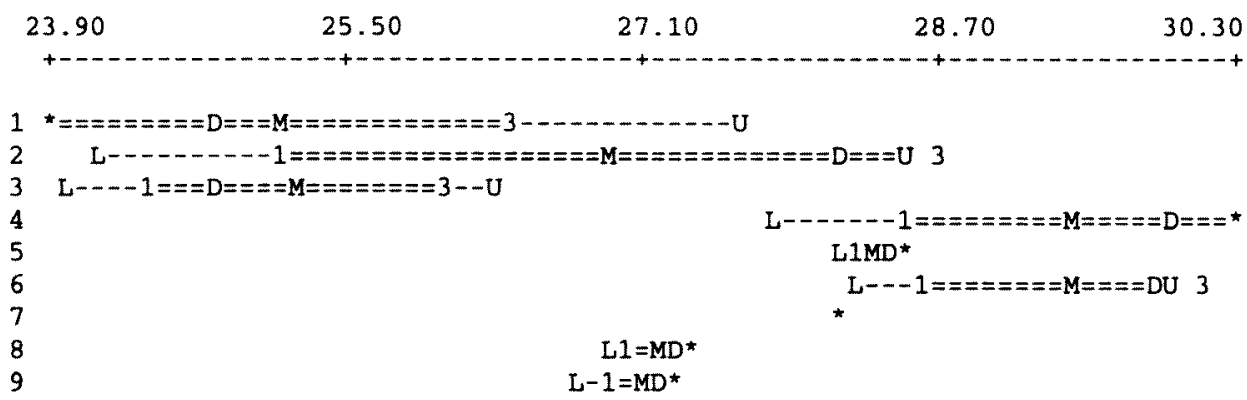

Precipitation wettest quarter $(\mathrm{mm}):($ Kruskal-wallis $=30.2, \mathrm{df}=8, \mathrm{p}=0.0002)$

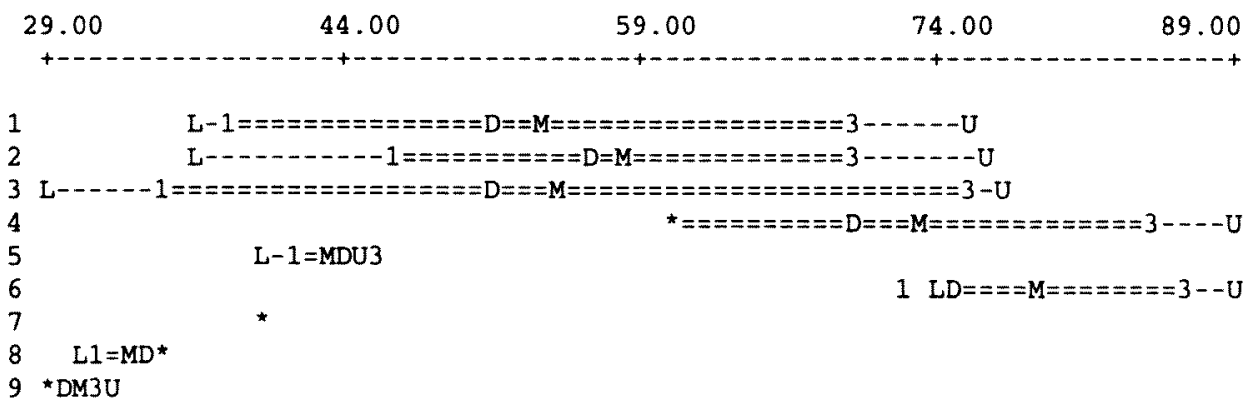


Figure 5 (cont.)

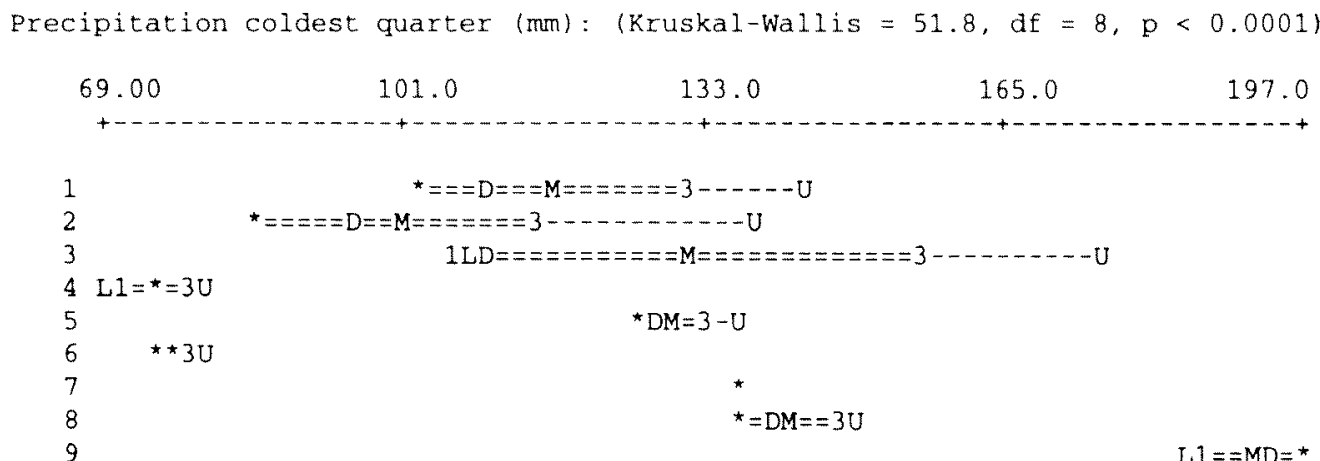

Annual precipitation $(\mathrm{mm}):$ (Kruskal-Wallis $=43.5, \mathrm{df}=8, \mathrm{p}<0.0001$ )

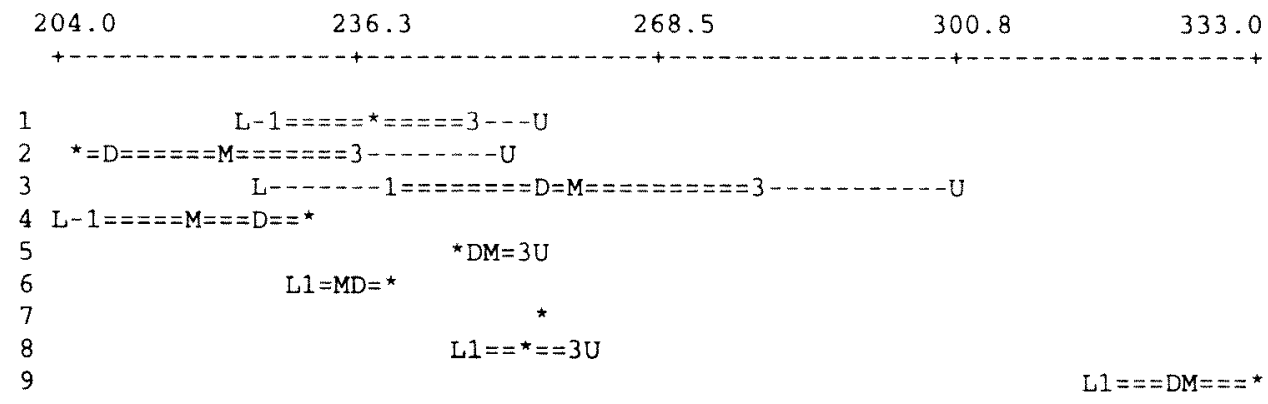

/ plot. The four subgroups show strong geographical and edaphic separation with subgroup 3a occurring on white dunes at Bush Bay and Cuvier, subgroup $3 b$ occurring on red sands at Cuvier, subgroup $3 c$ occurring on white sands at Edel Land and subgroup 3d occurring on red sands on Peron Peninsular. An separate analysis of sites in site group 3 confirmed highly faithful and constant species assemblages for subgroup $3 \mathrm{~b}$ (i.e. Triodia basedowii, Triodia pungens, Indigofera brevidens, Eragrostis lanata, Acacia rostellifera); 3c (i.e. Acanthocarpus robustus, Lepidium puberulum, Olearia sp. Edel, Poa drummondiana, Podolepis gnaphalioides, Triglochin trichophorum); and 3d (i.e. Acanthocarpus aff. robustus, Solanum orbiculare, Eragrostis dielsit, Dianella revoluta, Austrostipa elegantissima) while subgroup 3 a lacked species assemblages typical of the other subgroups.

Site group 4 consists of the inland Acacia shrublands of the Mardathuna - Kennedy Range footslopes - Gascoyne Junction area (Figure 4). Most sites are dominated by $A$. aneura, two have a eucalypt overstorey while one site (GJ1) is dominated by Senna artemisioides ssp helmsii. Average species richness is still high (39.6 taxa/ plot) but lower than site groups 2 and 3 . Species assemblage $A$ is typical of this site type with a much higher constancy than site type 2 which shares this assemblage. Assemblages $B$ and $C$ are largely faithful to site group 4 and differentiate between two subgroups, 4 a which tends to have shallower stony soils with significant calcrete in the upper layer and $4 \mathrm{~b}$ on deeper sandy soils (Wyrwoll, Stoneman, Elliott and Sandercock, 2000). Beard (1990) states that Mulga does not normally occur in the Camarvon region but this community type was widespread in the north east quadrant of the study area.

Site group 5 consists of eucalypt - Callitris or eucalypt - Acacia woodlands on red sand on the Toolonga plateau and site group 6 are sites of the red dunes on the top of the Kennedy Range (KE1, KE2) and tall dunes at Mardathuna (MR3). Both site group 5 and 6 differ from the other Carnarvon groups (site groups 1 to 4 ) in lacking most species from species assemblage $K$, which are generally ubiquitous (although site group 4 is under represented in some species). Species present from this assemblage differ between site groups 5 and 6 (Table 3). Species assemblage $\mathrm{P}$ is typical (ie showing both high degrees of constancy and fidelity) of site group 5 and species assemblage L is shared with other Carnarvon groups. Site group 6 is largely defined by the lack of assemblages that delimit the other Carnarvon groups, average species richness is low for site group 6 (21.7/ plot) 
while the red sands of the Toolonga plateau (site group 5) are much richer with an average species richness of 38.3 species/plot and similar to site groups 2 to 4 .

The affinities of site group 7, which consists of a single site NE2, are not clear. This site is a Banksia ashbyi-B. sceptrum woodland over heath on yellowish - red sands near the top of a dune. It was an unusual site in that no annuals were recorded on the plot in either year despite a significant annual flora being recorded at NE1 (only some $3 \mathrm{~km}$ to the NW) in 1996. It is likely that this site is transitional between the limestone heaths of site group 9 and the eucalypt woodlands of site group 5 . With the complete lack of annual taxa and only 12 perennial taxa recorded from this plot, its strongest relationship in the present classification is with the species poor site group 6 .

The remaining two site groups are typical of the vegetation types of the Irwin (Geraldton Sandplains) district. Site group 8 are eucalypt woodlands and tree heaths on red dunes immediately south of Shark Bay while site group 9 are limestone heaths or woodlands over limestone heaths between Kalbarri and Shark Bay (Figure 4). Species assemblage $N$ is most typical of site group 8 , largely comprising taxa of sandy habitats with a southwestern distribution. Average species richness for site group 8 was 30.0 taxa/plot. Species assemblages $\mathrm{S}$ and $\mathrm{T}$ are both highly faithful to site group 9. Both these assemblages are largely southwestern taxa common on calcareous sands. This site group can be divided into two subgroups - 9a occurring on massive limestones and $9 b$ occurring on deeper sands over limestone. Species in species assemblage $\mathrm{T}$ are southwestern taxa generally typical of massive limestones. Average species richness for site group 9 was 39.4 taxa/plot.

\section{Environmental correlates}

There is a strong correlation between the site groups and most of the major climatic gradients of the study area. The temperature and rainfall parameters derived from ANUCLIM show a very high degree of inter-correlation and it was not possible from the available data to determine to which aspect of these parameters the vascular flora is responding. Most parameters showed significant differences between site groups (Figure 5).

Patterns in mean annual temperature reflected geographical spread of site groups with the highest mean temperatures predicted for site groups 4 and 6 which are found in the north east of the study area and the lowest for site group 9 in the south west of the study area (Figures 4 and 5). The widespread site groups (1,2 and 3 ) had the widest range of predicted mean temperatures. The inland site groups had the highest diurnal temperature range and the highest annual temperature range (Figure 5).

Most of the study area had highest rainfall in winter, with the exception of sites from the Kennedy Range (site groups 6 and 4 in part) which showed significant rainfall during the warmest quarter (Figure 5). Annual precipitation was considerably higher in the area between Kalbarri and Shark Bay (site group 9) than in any other part of the study area, with the Acacia shrublands (site

Table 4 Mean values of soil parameters of nine groups derived by classifying sites according to their vascular flora. Values were derived from a bulked soil sample taken from 0-10 cm layer. (S.D. indicates level of significance in difference between the means based on Kruskal - Wallis non parametric one way analysis of variance ${ }^{*}=$ $\left.\mathrm{P}<0.05,{ }^{* *}=\mathrm{P}<0.01,{ }^{* * *}=\mathrm{P}<0.001\right)$

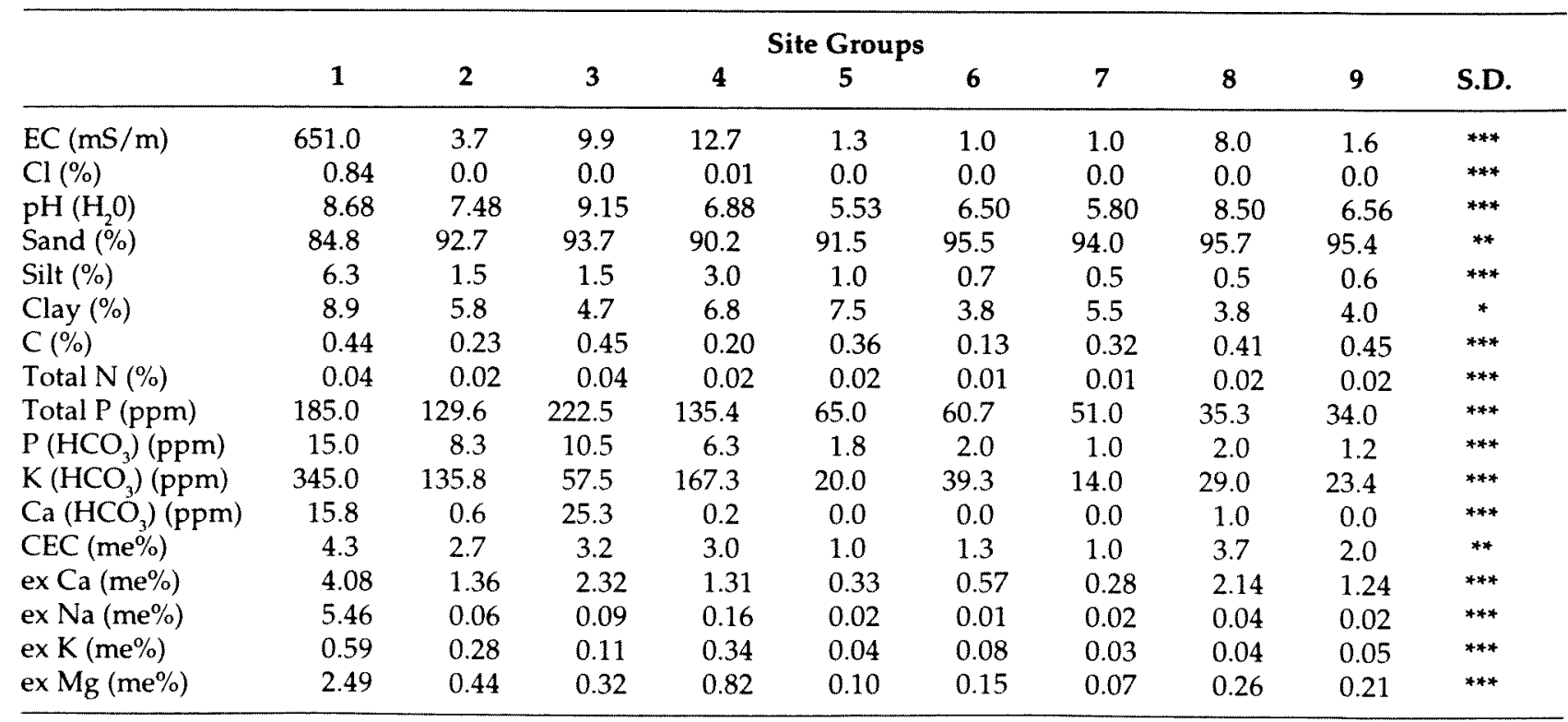


groups 2 and 4) having the lowest average rainfall (Figure 5).

The nine site groups differed significantly in terms of soil chemistry and soil mechanical analysis. Soils from site group 1 were the most markedly different soils with very high levels of electrical conductivity, $\mathrm{Cl}, \mathrm{K}$, exchangeable $\mathrm{Na}$, and exchangeable $\mathrm{Mg}$ (Table 4). Soils of site group 1 were generally loamy sands or gypsum (the two saltbush dominated plots that occurred on sand were the exceptions) while plots in the other site groups all occurred on sands except in site group 4 where two plots occurred on loamy sand.

Most of the soils were acid except for the saline site group (group 1; mean pH 8.7), the red sands south of Shark Bay (site group 8) with average $\mathrm{pH}$ of 8.5 and the coastal Acacia and Melaleuca shrublands (site group 3) which had a mean pH of 9.1. The calcareous nature of these coastal sands can be seen from the high values for $\mathrm{Ca}$ and / or high exchangeable Ca. The remaining soils ranged from almost neutral for the Acacia shrublands (site group 2) to strongly acidic for the red sands of the eucalypt woodlands of the Toolonga plateau (site group 5 - average $\mathrm{pH}$ of 5.5). The sand dunes on the top of the Kennedy Range and at Mardathuna (site group 6) were the poorest in terms of organic $C$ and $N$ while site groups 1 to 4 were the most fertile in terms of total $P$, available $P$, available $\mathrm{K}$, exchangeable $\mathrm{K}$ and exchangeable $\mathrm{Mg}$. The soils of site groups 5 and 6 were more similar to the Irwin (Geraldton Sandplains) vegetation types (site groups 8 and 9) than other Carnarvon vegetation types.

This strong regional patterning in soil types was generally not seen within the geographically segregated subgroups of site group 3 (only exchangeable $\mathrm{Ca}$ showed significant differences between the subgroups). The low number of replicates within each subgroup may be influencing these results. Significant differences were found for some soil properties of subgroups of site groups 2 and 4; these subgroups show less well defined but still significant geographical separation (latitude was significantly different between subgroup means at $\mathrm{P}<0.05$ for both groups) (Tables 5 and 6 ).

Separation of subgroups in site groups 2 and 4 was also strongly correlated to depth of soil profile (described in Wyrwoll, Stoneman, Elliott and Sandercock, 2000). In site group 2, subgroups a and c occurred on deep sands or gravels while plots in subgroup b had soil profiles either truncated on limestone or calcrete or had soils with significant calcrete or shell deposits in the profiles. Similarly more than half the plots in subgroup 4 a showed truncated profiles at depths of $30-90 \mathrm{~cm}$ underlain by massive calcrete or rock. All plots in subgroup $4 \mathrm{~b}$ were on deep sands $(>100 \mathrm{~cm}$ ) (Wyrwoll, Stoneman, Elliott and Sandercock, 2000). Site group 9 has a much smaller geographical spread than site
Table 5 Difference in soil chemistry and soil mechanical analysis between the subgroups in site group 2. Values were derived from a bulked soil sample taken from $0-10 \mathrm{~cm}$ layer. (S.D. indicates level of significance in difference between the means based on Kruskal - Wallis non parametric one way analysis of variance $\mathrm{ns}=$ not significant, ${ }^{*}=\mathrm{P}<$ $\left.0.05,{ }^{* *}=\mathrm{P}<0.01,{ }^{* *}=\mathrm{P}<0.001\right)$

\begin{tabular}{|c|c|c|c|c|}
\hline & & ubgroup & & \\
\hline & $2 a$ & $2 b$ & $2 c$ & SD \\
\hline $\mathrm{EC}(\mathrm{mS} / \mathrm{m})$ & 2.9 & 5.6 & 3.0 & ns \\
\hline $\mathrm{Cl}(\%)$ & 0.0 & 0.0 & 0.0 & ns \\
\hline $\mathrm{pH}\left(\mathrm{H}_{2} \mathrm{O}\right)$ & 7.49 & 8.26 & 6.83 & ns \\
\hline Sand $(\%)$ & 94.0 & 91.0 & 92.5 & ns \\
\hline Silt $(\%)$ & 1.0 & 2.7 & 1.1 & ns \\
\hline Clay $(\%)$ & 5.0 & 6.3 & 6.4 & ns \\
\hline$C(\%)$ & 0.20 & 0.20 & 0.30 & ns \\
\hline Total N $(\%)$ & 0.02 & 0.02 & 0.02 & ns \\
\hline Total P (ppm) & 145.7 & 138.0 & 103.8 & $*$ \\
\hline $\mathrm{P}\left(\mathrm{HCO}_{3}\right)(\mathrm{ppm})$ & 9.7 & 10.8 & 4.7 & $* *$ \\
\hline $\mathrm{K}\left(\mathrm{HCO}_{3}\right)(\mathrm{ppm})$ & 145.1 & 184.0 & 84.8 & $*$ \\
\hline $\mathrm{Ca}\left(\mathrm{HCO}_{3}\right)(\mathrm{ppm})$ & 0.3 & 1.2 & 0.3 & ns \\
\hline $\mathrm{CEC}\left(\mathrm{me}^{\%}\right)$ & 2.7 & 3.6 & 1.8 & $*$ \\
\hline $\mathrm{exCa}(\mathrm{me} \%)$ & 1.44 & 1.77 & 0.92 & ns \\
\hline ex $\mathrm{Na}(\mathrm{me} \%)$ & 0.04 & 0.09 & 0.06 & ns \\
\hline $\operatorname{ex~} \mathrm{K}(\mathrm{me} \%)$ & 0.30 & 0.40 & 0.17 & $*$ \\
\hline ex $\mathrm{Mg}\left(\mathrm{me}^{\%}\right)$ & 0.61 & 0.47 & 0.22 & * \\
\hline
\end{tabular}

Table 6 Difference in soil chemistry and soil mechanical analysis between the subgroups in site group 4. Values were derived from a bulked soil sample taken from $0-10 \mathrm{~cm}$ layer. (S.D. indicates level of significance in difference between the means based on Kruskal - Wallis non parametric one way analysis of variance $\mathrm{ns}=$ not significant, ${ }^{*}=\mathrm{P}<$ $0.05^{* *}=\mathrm{P}<0.01,{ }^{* * *}=\mathrm{P}<0.001$ )

\begin{tabular}{|c|c|c|c|}
\hline & \multicolumn{2}{|c|}{ Subgroups } & \multirow[b]{2}{*}{ SD } \\
\hline & $4 a$ & $4 b$ & \\
\hline $\mathrm{EC}(\mathrm{mS} / \mathrm{m})$ & 18.3 & 1.3 & $*$ \\
\hline $\mathrm{Cl}(\%)$ & 0.0 & 0.0 & ns \\
\hline $\mathrm{pH}\left(\mathrm{H}_{2} \mathrm{O}\right)$ & 7.18 & 6.28 & * \\
\hline Sand $(\%)$ & 89.1 & 92.3 & ns \\
\hline Silt $(\%)$ & 3.8 & 1.6 & $*$ \\
\hline Clay $(\%)$ & 7.1 & 6.1 & ns \\
\hline $\mathrm{C}(\%)$ & 0.20 & 0.20 & ns \\
\hline Total N $(\%)$ & 0.02 & 0.02 & ns \\
\hline Total P (ppm) & 141.9 & 122.5 & ns \\
\hline $\mathrm{P}\left(\mathrm{HCO}_{3}\right)(\mathrm{ppm})$ & 7.5 & 3.8 & $*$ \\
\hline $\mathrm{K}\left(\mathrm{HCO}_{3}\right)(\mathrm{ppm})$ & 211.3 & 79.5 & $* *$ \\
\hline $\mathrm{Ca}\left(\mathrm{HCO}_{3}\right)(\mathrm{ppm})$ & 0.3 & 0.0 & ns \\
\hline $\mathrm{CEC}(\mathrm{me} \%)$ & 3.9 & 1.3 & $*$ \\
\hline $\mathrm{exCa}(\mathrm{me} \%)$ & 1.61 & 0.73 & $*$ \\
\hline ex $\mathrm{Na}\left(\mathrm{me}^{\%}\right)$ & 0.24 & 0.02 & $*$ \\
\hline ex $\mathrm{K}(\mathrm{me} \%)$ & 0.41 & 0.18 & $* *$ \\
\hline ex $\mathrm{Mg}(\mathrm{me} \%)$ & 1.09 & 0.27 & * \\
\hline
\end{tabular}


groups 2, 3 or 4 and while the subgroups showed no significance difference in soil chemistry or soil mechanical analysis, subgroup 9 a occurred on shallow soil over limestone or in soils with significant limestone outcropping while subgroup $9 \mathrm{~b}$ occurred on deeper sands (Wyrwoll, Stoneman, Elliott and Sandercock, 2000).

\section{DISCUSSION}

\section{Flora}

Although the flora of the southern Carnarvon Basin is still imperfectly recorded, the current list of 2133 taxa is a marked improvement on the previous list for the entire Carnarvon Basin (an area of 91046 $\mathrm{km}^{2}$ ) of 1348 taxa (Keighery and Gibson, 1993). This improvement occurred at all levels; for example Kalbarri National Park had 206 taxa recorded by Burns (1984), 717 taxa for the area by Bellairs and Bellairs (1992) and we recorded 1071 taxa from within the boundaries of the National Park.

The study area has a predominantly arid flora of southern affinities with an overlay of temperate and tropical taxa at their range ends. The area is, however, species rich because it encompasses the change-over zone from the temperate to the arid zone.

Species level conservation of the vascular flora shows that the reserve network in the area is heavily biased towards the southern and coastal margin of the zone. The wetland [ $40 \%$ of the 265 wetland taxa listed by Gibson, Keighery and Lyons (2000) are not known from reserves in the Basin] and red sandplain floras are particularly lacking from the reserve network.

\section{Vegetation patterning}

In a regional survey of this type the degree of discrimination within and between site groups is limited by the number of plots established. In our survey, saltbush communities were only sampled at Bush Bay (BB1) and Boolathana (BO1). In both cases these sites classified most similar to a vegetation unit found nearby based on shared saline species in one case (species assemblage $\mathrm{O}$ - BB1) and a suite of annuals (species assemblage G - BO1) in the other. More sampling of this vegetation unit may have increased resolution of the current analysis.

Due to the limited number of sites it was also difficult to separate floristic variation due to regional environmental gradients from that associated with local edaphic factors. This is complicated in the present analysis by the correlation in regional climatic variation with distribution of major soil types. Within some site groups for which it was possible to distinguish subgroups, it was found that geographical segregation (and hence correlation with regional environmental gradients) was still apparent; nonetheless correlations with edaphic factors were clearly demonstrated within at least three site groups.

The climate of this region is unpredictable from year to year in terms of both precipitation and timing of rainfall events. During the two years of the study, at least one good season was experienced at all plots except NE2. For this reason the annual flora was included in the current analysis. However little is known of the patterns of accumulation of annuals at sites over longer time frames or the influence of time of year of rainfall events on the annual accumulation curves. Work of Zahran (1986) and Loneragan et al. (1991) provide some evidence of longer term climatic response by the herbaceous flora. Long term regular sampling at permanently located plots is needed quantify these processes in terms of changes in cover, changes in species occurrence and patterns of species accumulation through time. Annuals form a very significant proportion of the total flora of the region and therefore could be expected to be important in

Table 7 Percentage of taxa in each lifeform class by site group. Only taxa present in two or more sites are included. Percentage is based on total flora list recorded for each site group.

\begin{tabular}{|c|c|c|c|c|c|c|c|c|c|}
\hline \multirow[t]{2}{*}{ Life form } & \multicolumn{9}{|c|}{ Site Group } \\
\hline & 1 & 2 & 3 & 4 & 5 & 6 & 7 & 8 & 9 \\
\hline Annual herbs / geophytes & 60 & 44 & 40 & 42 & 58 & 18 & 17 & 14 & 16 \\
\hline Annual graminoides & 5 & 5 & 3 & 8 & 1 & 8 & 0 & 0 & 0 \\
\hline Perennial herbs & 9 & 7 & 5 & 4 & 4 & 4 & 0 & 2 & 8 \\
\hline Graminoides & 6 & 5 & 10 & 10 & 4 & 10 & 8 & 5 & 12 \\
\hline Shrub & 19 & 37 & 42 & 35 & 27 & 55 & 58 & 70 & 60 \\
\hline Trees & 0 & 2 & 0 & 1 & 5 & 4 & 17 & 9 & 3 \\
\hline Total number of species & 78 & 227 & 158 & 153 & 73 & 49 & 12 & 56 & 98 \\
\hline Total number of quadrats & 6 & 18 & 11 & 12 & 4 & 3 & 1 & 3 & 5 \\
\hline
\end{tabular}


defining the major compositional gradients across the region.

The analysis of the 63 primary sites shows an essentially similar result to the pattern discerned from our subjective appraisal of the biogeographic affiliations of the vascular flora. The vegetation patterning is closely correlated to major climatic gradients, as well as the distribution of different soil types across the study area. At a local scale edaphic factors were correlated with vegetation patterning but for the more geographically widespread groups it was not possible to separate effects of regional climatic differences and regional soil differences from local edaphic factors.

The analysis showed the southern part of the study area to be the most floristically complex with seven of the nine site groups $(78 \%)$ being recorded from the 17 southern most sites $(28 \%)$, reflecting the major change-over zone between the southwestem flora and the flora of more arid areas. This difference between the floras of the Geraldton Sandplain [Beard's (1990) Irwin district] and the Carnarvon can also be seen in an analysis of the proportional representation in lifeform class between the major classificatory groups (Table 7). Species rich shrublands are typical of the southwestern flora and site groups 8 and 9 show the expected high percentage of shrubs compared to annual herbs. Most of the Carnarvon groups (site groups 1 to 5) show the opposite trend with

Table 8 Comparison of nine major floristic site types identified in the present study with the land system and Pasture Types defined by Payne et al. (1987). Divisions in the table reflect Payne et al. (1987) higher vegetation - soil type groupings.

\begin{tabular}{|c|c|c|c|c|c|c|c|c|c|}
\hline \multirow{2}{*}{$\begin{array}{l}\text { Pasture Type/ } \\
\text { Land System }\end{array}$} & \multirow[b]{2}{*}{1} & \multirow[b]{2}{*}{2} & \multicolumn{4}{|c|}{ Site Groups } & \multirow[b]{2}{*}{7} & \multirow[b]{2}{*}{8} & \multirow[b]{2}{*}{9} \\
\hline & & & 3 & 4 & 5 & 6 & & & \\
\hline \multicolumn{10}{|c|}{ Acacia and eucalypt short grass forb } \\
\hline Nerren & & 1 & & & 4 & & & & \\
\hline Heath & & & & & & & & & \\
\hline Nanga & & & & & & & 1 & 3 & 3 \\
\hline Zuytdorp & & & & & & & & & 2 \\
\hline \multicolumn{10}{|l|}{ Acacia sandplain } \\
\hline Brown & & 4 & & & & & & & \\
\hline Lyons & & 3 & & & & 1 & & & \\
\hline Peron & & & 3 & & & & & & \\
\hline Sandplain & & 5 & & & & & & & \\
\hline Yalbalgo & & & & 3 & & & & & \\
\hline Yaringa & & 1 & & & & & & & \\
\hline \multicolumn{10}{|l|}{ Coastal dune shrub } \\
\hline Coast & & & 1 & & & & & & \\
\hline Edel & & & 2 & & & & & & \\
\hline Lyell & & & 1 & & & & & & \\
\hline \multicolumn{10}{|l|}{ Hard spinifex } \\
\hline Kennedy & & & & & & 2 & & & \\
\hline \multicolumn{10}{|l|}{ Soft spinfex } \\
\hline Cardabia & & & 4 & & & & & & \\
\hline
\end{tabular}

Acacia mixed shrub

Mary

Toolonga

Acacia short grass forb Windalia

Stony short grass forb Billy

$\begin{array}{ccc}\text { Mixed saltbush and bluebush } & & \\ \text { Delta } & 1 & \\ \text { Sable } & 1 & \\ \text { Wrarroora } & 1 & 2 \\ \text { Samphire } & & \\ \text { Birrida } & 1 & \\ \text { McLeod } & 2 & \end{array}$


moderate to low percentage of shrubs and high percentage of herbs. Site group 6, the species poor dune vegetation of the top of the Kennedy Range and Mardathuna, do not follow this trend with a much higher than expected representation of shrubs. Further sampling following good rains would be needed to confirm this finding.

Site group 7 consisted of only a single site (NE2) from which only 12 perennial taxa were recorded over the two major sampling periods. At site NE1 only $3 \mathrm{~km}$ distant large numbers of annuals were recorded in 1996 as with the other Nerren Nerren sites located some distance to the east. The soil chemistry, soil mechanical analysis and soil profile data (Wyrwoll, Stoneman, Elliott and Sandercock, 2000) were very similar between all Nerren Nerren sites. It is not clear if NE2 represents a local vegetation type that is naturally poor in annual species or had not received the same degree of rainfall as nearby sites.

The floristic classification shows broad general agreement with the biogeographical boundaries of Beard (1990) with the tree heath on red sandplain south of Shark Bay and the coastal limestone woodlands and heaths (site groups 8 and 9) falling within the Irwin district and the saline group, the Acacia shrublands, the coastal Acacia and Melaleuca shrublands, the Mulga shrublands, and the red sand dune vegetation groups of the Toolonga Plateau and the Kennedy Range falling in the Carnarvon district. The present classification does not support the inclusion of Edel Land as part of the Irwin district (renamed Geraldton Sandplain) as recently suggested by Thackway and Cresswell (1995).

Our analysis clearly shows the relationships between Edel Land and Peron Peninsular with the rest of the coastal belt of the Carnarvon district in site group 3. The Edel Land sites are separated as a subgroup, with this subgroup being most similar to the Peron subgroup. Our present data are not detailed enough to assess if Beard's phytogeographic boundaries are optimally placed (but see Gibson, Burbidge, Keighery and Lyons, 2000).

We found no strong correlation between vegetation patterning and the broadly mapped surficial geology (Hocking, 1985). All sites occurred on Pliocene to Holocene aged alluvial or colluvial deposits or aeolian sands except the lower slopes of the Kennedy Range (KE3-5 which occurred on early Permian to early Cretaceous sediments) and one site on lower slopes of the Pell Range (GJ1 which occurred on Permian sediments).

The only consistent land system mapping that has been undertaken across the study area is that produced by the Department of Agriculture rangelands survey group (Payne et al., 1987). This classification was based on 669 inventory sites sampled for perennial taxa and soil parameters in conjunction with aerial photograph interpretation.
The resulting mapping recognised 89 land systems in 17 vegetation alliances termed Pasture Types. Emphasis was given to perennial taxa important to stock production in the definition of Pasture Types (Payne et al., 1987). These Pasture Types were classified into five broad groupings based on affinity of species present (Southwestern vs. Eremaean) and broad soil type. Our plots covered 23 of these land systems in 11 Pasture Types in four of the broad vegetation - soil groupings (Table 8).

At the land system level there was only moderate correlation between the 23 land systems and the nine major floristic site groups. The nine site groups were represented by between one and seven land systems. Better correlation was evident between the floristic site groups and the major Pasture Types, with the nine site groups represented by between one and four Pasture Types. The correlation did not improve at the broadest vegetation - soil groupings (Table 8 ). This lack of correlation between the two studies relates to different aims and methodology used. The rangelands study used perennial taxa to help define mapped land units, while the present study used analysis of all taxa to define major floristic units across the study area. A reanalysis of the 63 sites using only perennial taxa could be expected to be more closely correlated with the rangeland classification.

\section{ACKNOWLEDGEMENTS}

Funding was provided by the Commonwealth through the National Reserves System Co-operative Program of the Australian Nature Conservation Agency (now Environment Australia), together with State funds provided by the Western Australian Department of Conservation and Land Management. Two referees provided valuable comment on an earlier draft of this paper.

\section{REFERENCES}

Alford J.J., Keighery, G.J. and Trudgen, M.E. (2000) Floras of the 29 islands of the Freycinet Estuary, Shark Bay World Heritage Area, Western Australia CALMScience (in press).

Anonymous (1997). Shark Bay Regional Strategy. Western Australian Planning Commission, Perth.

Austin, M.P. and Belbin, L. (1982). A new approach to the species classification problems in floristic analysis. Australian Journal of Ecology 7: 75-89.

Beard, J.S. (1975). The Vegetation of the Pilbara Area, 1; 1,000,000 map and explanatory notes. University of Western Australia Press, Nedlands.

Beard, J.S. (1976a). The Vegetation of the Murchison area, 1; 1,000,000 map and explanatory notes. University of Western Australia Press, Nedlands.

Beard, J.S. (1976b). The Vegetation of the Ajana Area, Western Australia. Vegmap Publications, Perth. 
Beard, J.S. (1976c). The Vegetation of the Shark Bay and Edel Areas, Western Australia. Vegmap Publications, Perth.

Beard, J.S. (1990). Plant Life of Western Australia. Kangaroo Press, Kenthurst.

Bellairs, D.R. and Bellairs, B. (1992). Checklist of Plants for Kalbarri and the Murchison Sandplain, (with supplement). Kalflora, Kalbarri.

Burbidge, A.A., Fuller, P.J. and Cashin, K. (1980). The wildlife of the proposed Toolonga Nature Reserve, Shark Bay Shire, Western Australia. Dept. Fisheries and Wildlife Report 39

Burbidge, A.A. and George, A.S. (1978). The Flora and fauna of Dirk Hartog Island, Western Australia. Journal of the Royal Society of Western Australia 60: 7190.

Burbidge, A.H., McKenzie, N.L. and Harvey, M.S. (2000) A biogeographic survey of the southern Carnarvon Basin, Western Australia: background and methods. Records of the Western Australian Museum Supplement No. 61: 1-12.

Burns, A.C. (1984). List of Plants: Kalbarri National Park. National Parks Authority, Perth.

CALM (1998). Declared Rare and Priority flora list - 21/10/ 1998. Unpublished Report, CALM, Perth.

Carolin, R.C., Rajput, M.J.M. and Morrison, D. (1992). Goodeniaceae. In A.S. George (ed) Flora of Australia, Volume 35. Brunoniaceae, Goodeniaceae, pp. 4-334. Bureau of Flora and Fauna and Australian Government Publishing Service, Canberra.

George, A.S (1999). William Dampier in New Holland: Australia's First Natural Historian. Bloomings Books, Hawthorn, Victoria.

Gibson, N., Keighery, G.J. and Keighery, B.J. (1997). Contributions of N.H. Speck to the biogeography of Proteaceae in Western Australia. Journal of the Royal Society of Western Australia 80: 73-77.

Gibson, N., Burbidge, A.H., Keighery, G.J. and Lyons, M.N. (2000). The temperate to arid transition of the Irwin - Carnarvon phytogeographic boundary, Western Australia. Records of the Western Australian Museum Supplement No. 61: 155-173.

Gibson, N. Keighery, G.J. and Lyons, M. (2000). The flora and vegetation of the seasonal and perennial wetlands of the southern Carnarvon Basin, Western Australia. Records of the Western Australian Museum Supplement No. 61: 175-199.

Green, J.W. (1985). Census of the Vascular Plants of Western Australia. Department of Agriculture, Perth.

Hocking, R.M. (1985). Geology of the Carnarvon Basin. Geological Survey of Western Australia Bulletin No. 133.

Hopper, S.D. and Maslin, B.R. (1978). Phytogeography of Acacia in Western Australia. Australian Joumal of Botany 26: 63-78.

Hussey, B.M.J., Keighery, G.J., Cousens, R.D., Dodd, J. and Lloyd, S.G. (1997). Western Weeds: a Guide to the Weeds of Western Australia. Plant Protection Society of Western Australia, Victoria Park, W.A.

Keighery, G.J. (1984). Phytogeography of the Monocotyledons of Western Australia. Kings Park Research Notes 8: 39-67.

Keighery, G.J. (1990). Vegetation and flora of Shark Bay, Western Australia. In P.F. Berry, S.D. Bradshaw and
B.R. Wilson (eds), Research in Shark Bay, pp. 61-88. Western Australian Museum, Perth

Keighery, G.J. (1995). How many weeds? An annotated list of the naturalised vascular plants of Western Australia. In G. Burke (ed), Invasive Weeds and Regenerating Ecosystems in Western Australia: Procedings of the Conference held at Murdoch University, July 1994. Institute for Science and Technology Policy, Murdoch University, Perth

Keighery, G.J. (1996). Phytogeography, biology and conservation of Western Australian Epacridaceae. Annals of Botany 77: 347-355.

Keighery, G.J. and Gibson, N. (1993). Biogeography and Composition of the flora of Cape Range peninsula, Western Australia. Records of the Western Australian Museum 45: 51-85.

Kenneally, K.F. (1978). Notes on the vegetation and flora of Rocky Pool, Gascoyne River. Western Australian Herbarium Research Notes 1: 29-39.

Loneragan, W.A., Holm, A.McR., Watson, I.W. (1991) Assessing long-term changes in native rangeland vegetation using functional species groups and multivariate analysis. Proceedings IVth International Rangeland Congress. April 22-26, 1991, Montpellier

McArthur, W.M. (1991). Reference Soils of South-western Atustralia. Department of Agriculture, Perth.

McMahon, J.P., Hutchinson, M.F., Nix, H.A. and Ord, K.D. (1995). ANUCLIM Users Guide, Version 1 Centre for Resource and Environmental Studies, Australian National University, Canberra, Australia.

Newbey, K.R. and Newbey, B.J. (1992). Notes on the Vegetation, Flora and Birds of Parts of the Kennedy Range, Gascoyne District, Western Australia. Unpublished report to CALM, Perth.

Payne, A.L., Curry, P.J. and Spencer, G.F. (1987). An inventory and condition survey of rangelands in the Carnarvon Basin, Western Australia. Department of Agriculture Western Australia Technical Bulletin No. 73.

Royce, R.D. (1962). Botany .In A.J. Fraser (ed), The results of an expedition to Bernier and Dorre Islands, Shark Bay, Western Australia in July 1959. Fauna Bulletin of Fisheries Department, Western Australia 2: 31-53.

Siegel, S. (1956). Non Parametric Statistics for Behavioural Sciences. McGraw-Hill, New York.

Sneath, P.H.A. and Sokal, R.R. (1973). Numerical Taxonomy: The Principles and Practice of Numerical Classification. Freeman, San Francisco.

Thackway, R. and Cresswell, I.D. (1995). (eds) An interim biogeographical regionalisation for Australia: a framework for establishing the national system of reserves, version 4.0. Australian Nature Conservation Agency, Canberra

Trudgen, M.E and Keighery, G.J. (1995). Flora of the Shark Bay World Heritage Area and Environs. Report prepared by Western Australian Department of Conservation and Land Management for the Australian Heritage Commission.

Tyler, J.P. (1988). Vegetation surveys near Lake MacLeod. Kingia 1: 49-74.

Wilson, P.G. (1984). Chenopodiaceae. In A.S. George (ed) Flora of Australia, Volume 4. Phytoloccaceae to Chenopodicaeae, pp. 81-317. Bureau of Flora and Fauna 
and Australian Government Publishing Service, Canberra.

Wyrwoll, K.-H., Courtney, J., and Sandercock, P. (2000) The climatic environment of the Carnarvon Basin, Western Australia. Records of the Western Australian Museum Supplement No. 61: 13-27.

Wyrwoll, K.-H., Stoneman, T., Elliott, G. and Sandercock, P. (2000) The geo-ecological setting of the Carnarvon Basin, Western Australia: geology, geomorphology and soils of selected sites. Records of the Western Australian Museum Supplement No. 61: 29-75.
Zahran, B.H.A. (1986) Forage composition and production of annual and biennial species on contrasting soils in rangeland grazed by sheep near Carnarvon, Western Australia. MSc (Agriculture) Thesis, University of Western Australia.

Manuscript received 4 February 2000; accepted 14 April 2000 . 


\section{APPENDIX 1}

Vascular plants recorded for study area, their CALM conservation codes and occurrence in major conservation reserves.

Explanation of codes:

Conservation code las defined by the Western Australian Department of Conservation and Land Management (1998)].

R. Declared Rare Flora - Extant taxa (= Threatened Flora = Endangered + Vulnerable $)$

Taxa which have been adequately searched for, and are deemed to be in the wild either rare, in danger of extinction, or otherwise in need of special protection, and have been gazetted as such, following approval by the Minister for the Environment, after recommendation by the State's Endangered Flora Consultative Committee.

1. Priority 1 - Poorly Known Taxa

Taxa which are known from one or a few (generally $<5)$ populations which are under threat, either due to small population size, or being on lands under immediate threat, eg. road verges, urban areas, farmland, active mineral leases, etc., or the plants are under threat from disease, grazing by feral animals etc. May include taxa with threatened populations on protected lands. Such taxa are under consideration for declaration as 'rare flora', but are in urgent need for further survey.

2. Priority Two - Poorly Known Taxa

Taxa which are currently known from one or a few (generally < 5) populations, at least some of which are believed to be under immediate threat (ie. not currently endangered). Such taxa are under consideration for declaration as 'rare flora', but are in urgent need of further survey.

\section{Priority Three - Poorly Known Taxa}

Taxa which are known from several populations, at least some of which are not believed to be under immediate threat (ie. not currently endangered). Such taxa are under consideration for declaration as 'rare flora', but are in need of further survey.

4. Priority Four - Poorly Known Taxa

Taxa which are considered to have been adequately surveyed and which, whilst being rare (in Australia), are not currently threatened by identifiable factors. These taxa require monitoring every $5-10$ years.

Distribution

Distributions refer to named places, pastoral leases, and conservation reserves (see below and Figure 1). Range limits refer to populations occurring at the limit of their known geographic range at or within the named place, pastoral lease or conservation reserve.

VCL Vacant Crown Land

WHA Shark Bay World Heritage Area

Conservation Reserve Codes

BINR Bernier Island Nature Reserve

DINR Dorre Island Nature Reserve

CNR Cooloomia Nature Reserve

FPNP Francois Peron National Park

KNP Kalbarri National Park

KRNP Kennedy Range National Park

TNR Toolonga Nature Reserve

ZNP Zuytdorp National Park 
Acanthaceae

Dipteracanthus australasicus subsp. australasicu.

Harnieria kempean

Hypoestes floribunda

\section{Adiantaceae}

Anogramma leptophyllo

Cheilanthes austrotenuifolia

Cheilanthes lasiophylla

Cheilanthes sieber

aceae

* Agave americana

Aizoaceae

* Carpobrotus aequilaterus

Carpobrotus sp. (GJK \& NG 1707)

Carpobrotus sp. (GJK

Disphyma crassifolium subsp. clavellatum

Gunniopsis rodwayi

Gunniopsis septifraga

Mesembryanthemum crystallinum

Sesuvium portulacastrum

Tetragonia coromata

$S$ limit FPNP

Tetragonia cristata

Endemic WHA

* Tetragonia decumbens

Tetragonia diptera

Tetragonia implexicoma

Tetragonia tetragonoides

Trianthema oxycalyptra var. oxycalyptra

Trianthema pilosa

Trianthema triquetra

Trianthema turgidifolia

Zaleya galericulata

\section{Amaranthaceae}

Alternanthera nodiflora

* Alternanthera pungens

Amaranthus clementi

Amaranthus mitchellii

Amaranthus pallidiflorus

Gomphrena canescens.

Gomphrena cunninghami

Hemichroa diandra

Ptilotus aervoides
Ptilotus aff. chamaecladus

Ptilotus aff. grandiflorus 
Ptilotus divaricatus var divaricatus

Ptilotus divaricatus var. rubescens

Ptilotus drummondi var. drummendii

Ptilotus drummendii var. drummendii

Ptilotus drummondii var. minor

Ptilotus eristrichus

Ptilotus exaltatus var exaltatus

Ptilotus gaudichaudii var goudichaudi

Ptilotus gaudichaudii var. parviflorus

Piletus grandifforus var. grandiftorus

Ptilitus grandifloras var. lepidus

Ptilotus helipteroides

Ptilotus humilis subsp. humilis

Ptilotus latifolius

Ptilotus macrocephalus

Ptilotus manglesit

Ptilotus marray

Ptilotus obovatus var. Lancifolius

Ptilotus obovatus var. obovatus

Ptilotus petiolatus

Ptilotus polystachyus forma polystachyus

Ptilotus roei

Ptilotus rotundifolius

Ptilotus schwartzil var georgei

Ptilotus schwartzii var schwartio

Ptilotus spathulatus

Ptilotus stipitatus

Ptilotus stirlingii var. pumilus

Ptilotus stirlingii var. stirlingit

Ptilotus villosiflorus

\section{Amaryllidaceae}

Crinum flaccidum

\section{S limit Lake MaCleod}

\section{Anthericaceae}

Arnocrinum drummondii

Borya scirpoidea

Borya sphaerocephala

Caesia alfordii $\mathrm{ms}$

Chamaescilla corymbosa

Corynotheca micrantha var. acanthoclada

$N$ limit ZNP

$N$ limit KNP

$N$ limit KNP

$\mathrm{N}$ limit Carrang Stn. 
Corynotheca micrantha var. micrantha

Corynotheca pungens

Dichopogon preissi

Dichopogon tyleri

Laxmannia sessiliflora subsp. sessiliftora

Murchisonia fragrans

Murchisonia volubilis

Sowerbuea laxiflora

Thysanotus arenarius

Thysanotus brittanii ms

Thysanotus kalbarriensis ms

Thysanotus manglesianus

Thysanotus putersomii

Thysanotus sparteus

Thysanotus speckii

Thysanotus teretifoliu

Thysanotus thyrsoideus

Tricoryne aff. corynothecoides (GJK \& NG 1274)

Tricoryne arenicola $\mathrm{ms}$

Tricoryne corynothecoides

Tricoryne elatior

Apiaceae

Actinotus leucocephalu.

Apium annuum

Apium prostratum

Cyclospermum leptophyllum

Daucus glochidiatus

Hydrocotyle pilifera var. glabrata

Hydrocotyle rugulosa

Hydrocotyle scutellifera

Neosciadium glochidiatum

Platysace commutata

Platysace junce

Platysace sp. Kalbarri (D.\& B.Bellairs 1383)

Platysace sp. Kennedy (P.G.Wilson 8450)

Platysace xerophila

Trachymene aff. oleracea (GJK \& NG 719)

Trachymene coerulea var. leucopetal

Trachymene cyanopetala

Trachymene elachocarp

Trachymene glaucifolia

Trachymene ornata

Uldinia ceratocar
S limit Tamala Stn.

$N$ limit KNP

Endemic to Study Area

$\mathrm{N}$ limit CNR

N me limit KNP/TNR

N limit Tamala Stn.

Endemic KNP

N limit Nanga Stn.

N limit Carrang Stn

$\mathrm{N}$ limit KNP

$N$ limit Tamala Stn.

(

1

1

CNR FPNP BINR DINR KRNP

1
1
1
1
1
1
1
1
1
1
1
1
1
1
1

1

1

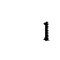

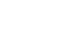

$\mathrm{N}$ limit KNP 


\section{Arecaceae}

* Phoenix dacrylifera

\section{Asclepiadaceae}

Chanchum aff. floribundum (KRN 11847 )

Cynanchum floribundum

Gymnanthera cunninghami

$S$ limit from (Cape Range)

Gymnema granitica

$N$ limit FPNP

Rhuncharrhena linearis

Sarcostemma viminale subsp. australe

Asphodelaceae

Asphodelus fistulosiu

Bulbine semibarbata

\section{Aspleniaceae}

Pleurosorus rutifotius

\section{Asteraceae}

condensatum

Actinobole drummondiana

Actinobole uliginosum

Angianthus acrohyalinus

Angianthus c'unninghumit

Angianthus microcephalus

Angianthus milnet

Angianthus preissianus

Argianthus pusillus

Angianthus sp. (A.S. George 11362)

Angianthus sp. (A.S.George 11471)

Angianthus tomentosus

* Arctotheca calendula

* Arctotheca populifolia

* Aster subulatus

Asteridea asteroides

Bellida graminea

* Bidens bipinnata

Blennospora drummondii

Brachyscome cheilocarpa

Brachyscome ciliaris

Brachyscome ciliocarpa

Brachyscome halophila

Brachystome iberidifolia
$N$ limit DHI/FPNP

S limit Hamelin Stn

S limit Hamelin Stn.

Endemic WHA

$\mathrm{N}$ limit DHI

$\mathrm{N}$ limit KNP 
Brachyscome latisquamed

Brachyscome lineariloba

Brachyscome perpusillo

Calocephalus aervoides

Code

Calocephalus knappii

Calocephalus multiflorus

Calocephalus sp. Pilbara (MET 11454)

Calocephalus sp. Wittenoom (A.S. George 1082

Calotis hispidula

Calotis multicaulis.

* Centaurea melitensis

Centipeda cunninghamii

Centipeda minima

Centipeda thespidioides

Cephalipterum drummondii

Ceratogyne obionoides

Chondropyxis halophila

Chrysocephalum apiculatum

Chrysocephalum semicalvum

Chthonocephalus muellerianus

Chthonocephalus oldfieldianus

Chthonocephalus pseudevax

Chthonocephalus spathulatus

Chthonocephalus tomentellus

* Cotula bipinnat

Cotula coronopifolia

Cotula cotuloides

Cotula sp. Kalbarri (GJK \& NG 2044)

I

1

Cratystylis subspinescens

Decazesia hecatocephala

Erymophyllum compactum

Erymophyllum ramosum

Erymophyllum ramosum subsp. involucratum

Erymophyllum ramosum subsp. ramosum

Erymophyllum tenellum

Gilberta tenuifolia

$N$ limit Coburn Stn.

Endemic Carnarvon to Shark Bay

Gilruthia osbornei

* Gnaphalium polycaulon

S limit DINR 
* Hedypmois rhagadioloides

mic southern Carnarvon Basin

* Helianthus arnuas

Helipterum craspedioides

Hyalosperma costula

Hyalosperma demissam

Hyalosperma glutinosum subsp. glutinosum

Hyalospermia glutinostam subsp. venustum

Hypochaeris glabra

Isoetopsis sraminitolia

Lactuca serriolia

Lagenifera huegelit

Lawrencella davenpurtii

Lawrencella rosea

Leucochrysum fitzyibbemii

Leucophyta brownt

Millotia depauperata

Milloriat jacksonit

Millotia myosotidifolia

Minuria integerrima

Myriscephalus gascoynensis ins

Myriocephalus guerinac

Myricephalus nudus

Myricephalus pyzmoeus

Myriocephatus sp. (Demarz 12152)

Myriecephalus sp. (Nordenstam \&Anderberg 188)

Olearia adenolasia

Olearia aff axillaris (GJK/NG 1025)

Olearia axillaris

Olearia dampieri subsp. dampieri ms

Olearia dumpieri subs ceremicto

Olearia humilis

Olearia imbricat

Olearia muelleri

Olearia orcidentissima

Olearia pimelendes

Endemic WHA

Olearia revoluta

Olearia stuart

* Osterspermum calendulacent

N limit Tamala Stn.

$N$ limit Hamelin Stn

$\mathrm{N}$ limit Tamala Stn.

Endemic Carnarvon Basin

Endemic Carnarvon Basin

Endemic WHA

Endemic WHA

Pluchea rabellifinora

Pluchea squarrasa

Pluchea tetranthera

Podolepis auriculata

Podolepis canescen

S limit Wooramel R

$S$ limit Wooramel R.

$\mathrm{N}$ limit Giralia 
Podolepis gardner Podolepis lessomii

Podolepis microcephala

Podotheca angustifolia

Podotheca gnaphalioide

S limit Tamala Stn.

Podotheca pollackii

$N$ limit DHI

$\mathrm{N}$ limit Woodleigh Stn.

Pogonolepis muellerian

Pogonolepis stricta

* Pseudognaphalium lutesalbum

Pterocaulon sphacelatum

Pterochaeta paniculata

* Reichardia tingitana

Rhodanthe charsleyae

Rhodanthe chlorocephala subsp. splendida

Rhodanthe citrina

Rhodanthe condensata

Rhodanthe corymbosa

Rhodanthe cremea

Rhodanihe cremea

Rhodanthe laevis

Rhodanthe manglesii

Rhodanthe margarethae

Rhodanthe maryonii

Rhodanthe oppositifolia subsp. oppositifolia

Rhodanthe oppositifolia subsp. ornata

Nimit woodeigh Sth.

Rhodanthe polycephala

Rhodanthe psammophila

Rhodanthe rubello

Rhodanthe sp. Overlander (P.S.Short 2096)

Rhodanthe spicata

Rhodanthe sterilescens

Rhodanthe stricta

Schoenia ayersii

Schoenia cassiniana

Schoenia filifolia subsp arenicola

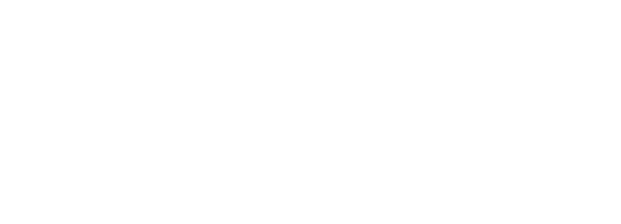

$\mathrm{N}$ limit KRNP

Endemic WHA

Senecio glossanthus

Senecio gregorii

Senecio lautus subsp. dissectifoliu

Senecio lautus subsp. maritimus

* Sonchas oleraceus

* Sonchus tenerrimus

Sondottia glabrata

Streptoglossa cylindriceps

Streptoglossa liatroides

Streptoglossa tenuiflora

Trichanthodium scarlettianum 
* Ursinia anthemoides

* Vellereophyton dealbatum

Vittadinia cervicularis var cervicularis

Vittadinia cervicularis var. oldfieldi

Vittadinia eremaea

Watzia acuminata var. acuminat

Waitzia acuminata var albicans

Waitzia corymbose

Waitzia nitida

$\mathrm{N}$ limit Hamelin Stn

$\mathrm{N}$ limit ZNP

Waitzia podolepis

Avicenniaceae

Avicennia marina

Boraginaceae

Cynoglessum austrate

* Echium plantagineum

Halgania aff. argyrophylla

Halgania aff. littoralis

Halgania anagalloides var. anagalloides $\mathrm{ms}$

Halgania anagalloides var, preissiana $\mathrm{ms}$

Halgania argyrophyll

Halgania bebrana

Halgania cyanea

Halgania cyanea var. latisepula ms

Halgania gustafsenii var. compactus ms

Halgania littoralis

Halgania sericiflora

Halgania viscosa

Heliotropium curassavicum

Heliotropium heteranthum

Helistropium paniculatum

Heliotropium undulatum

Omphalelappula concava

Plagiobothrys plurisepalus

Trichodesma zevlanicum var. zevlanicum

\section{Brassicaceae}

* Brassica juncea

* Brassica tournefortii

* Cakile maritima

* Coronopas didymus

* Diplotaxis muralis

* Diplotaxis tenuifolia

* Hymenolobus procumbens

Lepidium biplicatum

$\mathrm{N}$ limit DINR

\section{$\mathrm{N}$ limit KNP}

$\mathrm{N}$ limit Tamala Stn

S limit FPNP

Lepidium foliosum

Disjunct from Mt Jackson 


Lepidium linifolium
Lepidium lyratogynum
Lepidium oxytrichum
Lepidium phlebopetalum
Lepidium platypetalum
Lepidium pseudoruderale
Lepidium puberulum
Lepidium rotundum
Lepidium scandens
Menkea australis
Menkea villosula
Phlegmatospermum drummondii
Raphanus raphanistrum
* Raphanus sativus
* Sisymbrium erysimoides
* Sisymbrium irio
* Sisymbrium orientale
Stenopetalum anfractum
Stenopetalum filifotium
Stenopetalum lineare
Stenopetalum pedicellare
Stenopetalum robustum
Stenopetalum sphaerocarpum
Caesalpiniaceae
Labichea cassioides
Labichea eremaea
Labichea lanceolata subsp. lanceolata
Labichea teretifolia subsp. teretifolia
Petalostylis cassioides
Petalostylis labicheoides
Senna artemisioides subsp. filifolia
Senna artemisioides subsp. helmsii
Senna artemisioides subsp. x sturtii
Senna glutinosa subsp. charlesiana
Senna glutinosa subsp. chatelainiana
Senna glutinosa subsp. x luerssenii
Senna notabilis
Senna pleurocarpa var. pleurocarpa
Senna sp. Austin (A.Strid 20210$)$
Senna sp. Billabong (J.D.Alonzo 721 )
Senna sp. Meekatharra (E. Bailey $1-26$ )
Senna sp. Tamala (M.E.Trudgen 7334 A)

Lepidium lyratogynum

Lepidium platypetalum

Lepidium pseudoruderale

Range extension from Wongan Hills 
Capparaceae

Capparis lasiuntha

Capparis spinosa var nummularia

Cleome uncifer

Cleome viscosa

\section{Caryophyllaceae}

* Cerastium glomeratum

Corrigioles litorahts

Gypsophila australis

* Petrorhagia velutina

Polycarpaea corymbosa

Polycarpon tetraphyllum

Sagina apesala

Silene gallica var. gallica

- Silene nocturna

* Spergula arvensis

- Spergularia dicandra

* Spergularia rubra

Stellaria filiformis

* Stellaria media

Casuarinaceae

Allocasuarina acutivalvis subsp. acutivalvis

Allocasuarina campestris

Allocasuarina corniculata

Allocasuarina dielsiana

Allocasuarina helmsii

Allocasuarina huegeliana

Allocasuarina humilis

Allocasuarina lehmanniana

Casuarina obesa

\section{$N$ limit ZNP}

N limit Nerren Nerren Stn.

N limit DHI

limit Tamala Stn

elastraceae

Psammomoya choretroides

Psammomoya ephedr

$\mathrm{N}$ limit KNP

Centrolepidaceae

Apheliu nutuns

Centrolepis aristata

Centrolepis cephaloformis subsp. murrayi

$\mathrm{N}$ limit KNP

$\mathrm{N}$ limit Kalbarri Area 
Centrolepis drummondian

Centrolepis eremica

Centrolepis glabra

Centrolepis humillima

$\mathrm{N}$ limit KNP

Centrolepi.

$\mathrm{N}$ limit $\mathrm{DHI}$

\section{Chenopodiaceae}

Atriplex amnicola

Atriplex bunburyana

Atriplex cinerea

Atriplex codonocarpa

Atriplex holocarpa

Atriplex isatidea

Atriplex lindleyi subsp. inflatu

Atriplex nummularia subsp. spathulata

Atriplex paludosa subsp. baudinii

Atriplex paludosa subsp. moquiniana

Atriplex semilunaris

Atriplex spongiosa

Atriplex vesicaria subsp. incompta

Atriplex vesicaria subsp. variabilis

* Chenopodium ambrosioides

Chenopodium auricomum

Chenopodium cristatum

Chenopodium curvispicatum

Chenopodium desertorum

Chenopodium gaudichaudianum

Chenopodium melanocarpum forma leucocarpum

Chenopodium melanocarpum forma melanocarpum

* Chenopodium murale

Chenopodium pumilio

Didymanthus roei

$N$ limit FPNP

Dissocarpus paradoxus

Dysphania glandulosa

Dysphania glomulifera subsp. eremaed

Dysphania kalpari

Dysphania plantaginella

Dysphania platycarpa

Dysphania rhadinostachya subsp. inflata

Dysphania rhadinostachya subsp. rhadinostachya

Dysphania sphaerosperma

Einadia nutans

Enchylaena tomentosa var. tomentosa

Eremophea aggregata

Eriochiton sclerolaenoides

Halosarcia auriculata

Halosarcia doleiformis 
Hatosatrcia indica subsp te iostachya

Halessarcia leptociada

Haloserscia pelatata

Halosarcia pergranutata subsp. pergranulata

Halosarcia prumosa

Halosaria prerygosperma subsp. denticulara

Halosarcia mengesperma subsp. pterygosperma

Maireana amoenct

Maireana aphylla

Matireana appressa

Maireana atkinsiamu

Maireana camosa

Matireana comvext

Maireana georgei

Maireana integra

Mareana lanosa

Maireana lobiflora

Mairecand melanocoma

Maireana oppositifolia

Mareana pentagona

Mareama planifolia

Matreana platycarpa

Maireana polypierygiat

Matreana scleroptera

Marreana stipitata

Maireana thesiosides

Mareana tomenosa

Matreana trichopterd

Maireana villosat

Neobassia astrecarpa

steocapum acropterum var acropterum

Rhatodia bactata

Rhagodia crassifolia

Rhagodia eremaed

Rhagrodia latifotia subsp. Latifolia

Rhagedia latifolla subsp. recta

Rhusediu preissii subsp. robou

Rhagoda pretssti subsp. wowata

Sulsola kati

Sarcocomia blackiana

Sarcocormia quinqueflor

Sclerslaena bicuspis

Disjunct from South Australia

S limit Tamala Stn. 
Sclerolaena diacantho

Sclerolaena eriacantha

Sclerolaena eurotioides

Sclerolaena forrestiana

Sclerolaena limbata

Sclerolaena medicaginoides

Sclerolaena obliquicuspis

KNP TNR ZNP CNR FPNP BINR DINR KRNP

Sclerolaena recurvicuspis

Sclerolaena stylosa

Sclerolaena tridens

Sclerostegia disarticulata

Suceda australis

Tecticornia arborea

Tecticornia verrucos

Threlkeldia diffusa

Chloanthaceae

Cyanostegia angustifolia

Dicrastylis fulva

Dicrastylis linearifolia

Dicrastylis micrantha

Dicrastylis sp. Peron Peninsula (M.E.Trudgen 7373)

Dicrastylis sp. Shark Bay (J.J.Alford 1318)

Lachnostachys eriobotrya

Lachnostachys ferruginea

Physopsis chrysophylla

Pityrodia atriplicina

Pityrodia axillaris

Pityrodia cuneata

Pityrodia glabra

Pityrodia glutinosa

Pityrodia hemigenioides

Pityrodia loxocarpo

Pityrodia oldfieldii

Pityrodia paniculata

Pityrodia teckiana

Pityrodia verbascina

Spartothamnella teucriiflora

N limit Nerren Nerren Stn

$N$ limit Meadow Stn

$N$ limit Nanga Stn

Endemic WHA

Hypericum gramineum

Hypericum japonicum

Endemic WHA \& $\mathrm{S}$ to Murchison $\mathrm{R}$

$\mathrm{N}$ limit DHI

$\mathrm{N}$ limit Peron Peninsular / DHI

Endemic WHA

Endemic Nerren Nerren Stn. area

N limit Eurardy Stn.

N limit Tamala Stn

$S$ limit Coburn Stn.

\section{Coceae}

Burchardia multiflora 
Wurmbea deserticol

Wurmbea inframedian

Wurmbea murchisoniand

Wurmbea odorata

Wurmbea pygmaea

Wurmbea sp. (KRN 11582)

Wurmbea tenella

$\mathrm{N}$ limit Tarnala Stn

\section{Commelinaceae}

Cartonema philydroides

\section{$\mathrm{N}$ limit KNP}

Convolvulaceae

$$
\text { Bonamia rosea }
$$

Convolvulus erubescen

Convolvulus remotus

Evolvulus alsinoide

Ipomoea costata

Ipomoea muelleri

Ipomoea pes-iaprae subsp. brasiliensi.

Polymericasp. (R.J. Cranfield 2563)

Porana sericea

Wilsonia backhouse

Wilsonia humilis

\section{S limit FPNP}

$\mathrm{N}$ limit Carrang Stn

$\mathrm{N}$ limit Salutat

$\mathrm{N}$ limit FPNP

Crassula collerata var acuminate

Crassula colorata var colorata

Crassula decumbens var. decumbens

Crassula exserta

Crassua natans

Crasula pedicellosas

Cucurbitaceae

Mukia maderaspatana

S limit Wooramel $R$

\section{Cunoniaceae}

Aphanopetalum clematideum

N limit DHI

$\mathrm{N}$ limit CNR

Actinostrobus arenarius

Cuscutaceae

* Cuscuti epithymum

* Cuscuta planiflera

Cuscuta victoriana 


\section{Cymodoceaceae}

Amphibolis antarctica

Amphibolis griffithii

Cymodocea angustata

Cymodocea serrulat

Halodule uninervis

Syringodium isoetifolium

\section{Cyperaceae}

Baumea acuta

Baumea articulata

Baumea juncea

$N$ limit KNP

Bulbostylis barbat

$N$ limit KNP

Causus dioicu

$\mathrm{N}$ limit KNP

Chrysitrix distigmatosa

$N$ limit CNR

Cyperus aff. cunninghamii (GJK \& NG 592)

Cyperus alterniflorus

Cyperus bifax

Cyperus blakeanus

Cyperus bulbosus

Cyperus castaneu.

Cyperus difformis

Cyperus gymnocaulos

* Cyperus hamulosus

Cyperus ixiocarpus

Cyperus rigidellus

Cyperus squarrosus

Cyperus vaginatus

Eleocharis acuta

Eleocharis geniculata

Eleocharis pallens

Gahnia lanigera

Gahnia trifida

Isolepis cernua

Isolepis congrua

Isolepis cyperoides

Isolepis marginat

Isolepis nodosa

Isolepis setiformis

Lepidosperma angustatum

Lepidosperma rupestre

Lepidosperma scabrum

Lepidosperma tenue

Lipocarpha microcephala

Mesomelaena preissii

Mesomelaena pseudostygia

S limit Gascoyne R

$\mathrm{N}$ limit DHI

$N$ limit KNP

$\mathrm{N}$ limit DHI

$N$ limit Carrang Stn

$N$ limit ZNP

Endemic KNP

$N$ limit KNP

$\mathrm{N}$ limit KNP

$\mathrm{N}$ limit KNP

N limit Carrang Str. 
Schoenoplectus subulatus

$N$ limit KNP

$N$ limit KNP

Schenus andren

Schoenus standestinus

$N$ limit KNP

$N$ limit KNP

Schoenus globifer

Schoenus grandiflerus

$N$ limit CNR

$N$ limit Murchison House Stn

Schoenus he cundrus

Schoenus humilis

Schoenus latitans

Shoenus nanus

$N$ limit CNR

Schoenus odomecarpus

Schoenus pleiostemeneus

Schoenus sp. (Keighery \& Alford 1966

limit KNP

Scherens sp. G Broad Sheath (K.L. Wilson 2633

$N$ limit KNP

N limit Tamala Stn

$N$ limit Carrang Stn.

Endemic Kalbarri area

Schoenu. sp. Murchison (K.L. Wilson 2647)

Endemic KNP to TNR

Scheenas varicellate

$N$ limit KNP

Tetraria merecarpa

$N$ limit CNR

N limit FPNP

Slimit Quobba Stn

Acanthocarpus aff. robustus (Hopper 1367

Acanthocarpus humilts

Acantherarpus parviflorus

Acanthocarpus preissi

Acanthocarpas robustus

Acanthourpas verticillatus

Calectasia cyented

Calectasia shoudiflen

Chamuexeros serra

Lomandra hastitis

Lomandra maritima

Xerolinom divaricato

Dilleniaceae

Hibbertia acerosa

Hibbertia comspicua

Hibbertia desmophylla

Hibbertic exasperatu

Hibhertia glomerosa

Hibbertia huegeli

Hibbertia hypericoides

Hibbertia potentilliflur

Hibbertici racemose

Hibbertia sp. Red Bluff (J.R. Wheeler 2376)

$S$ limit ZNP

S limit Tamala Stn.

$\mathrm{N}$ limit KNP

$N$ limit KNP

N limit KNP

N limit KNP

N limit Carrang Sin.

$N$ limit ZNP

$\mathrm{N}$ limit Nanga Stn.

$\mathrm{N}$ limit KNP

$N$ limit KNP

$N$ limit KNP

$N$ limit KNP

$N$ limit KNP

N limit KNP

$N$ limit Tamala Stn.

$\mathrm{N}$ limit CNR 
Hibbertia spicata subsp. spicata

Hibbertia stellaris

Hibbertia subvaginata

$\mathrm{N}$ limit KNP

$\mathrm{N}$ limit CNR

KN

Dioscoreaceae

Dioscorea hastifolia

Droseraceae

Drosera bulbosa

Drosera coolamon ms

Drosera ericksoniae

Drosera glanduliger

Drosera indica

Drosera macrantha subsp. macrantha

Drosera menziesii subsp. thysanosepala

Drosera neesii subsp. borealis

Drosera radicans

Drosera ramellosa

Drosera stolonifera subsp. humili.

Drosera stolonifera subsp. prostrata

Elatinaceae

Bergia auriculata

Bergia perennis subsp. obtusifolia

Elatine gratioloides

Emblingiacea

Emblingia calceoliftor

Epacridaceae

Astroloma glaucescens

Astrotoma serradifota

Astroloma xerophyllum

Brachyloma sp. Kalbarri (A.H. Burbidge 4504)

Conostephium preissii

Letucopogon aff cordifolius

Leucopogon aff. strongylophyllus

Leucopogon allittii

Leucopogon conostephioides

Leucopogon cordifolius

Leucopogon crassiflorus

Leacopogon hamulosus

Leucopogon hispidus

Leucopogon leptanthus

Leucopogon marginaru

Leucopogon parviflorus
$\mathrm{N}$ limit Salutation IsI.

$N$ limit KNP

$N$ limit KNP

$N$ limit KNP

$\mathrm{N}$ limit KNP

$N$ limit KNP

$N$ limit ZNP

$\mathrm{N}$ limit ZNP

$\mathrm{N}$ limit KNP

$\mathrm{N}$ limit KNP

$\mathrm{N}$ limit Nanga Stn.

$S$ limit KNP-Nanga Stn.

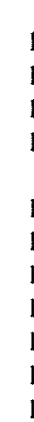

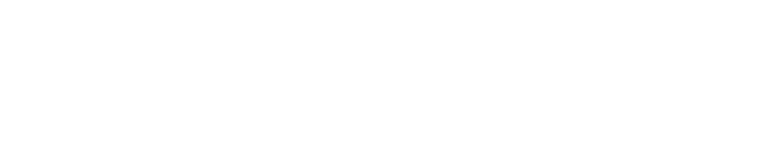

$N$ limit KNP

$N$ limit KNP

$N$ limit KNP

$\mathrm{N}$ limit KNP

N limit CNR

$\mathrm{N}$ limit KNP

$N$ limit KNP

$N$ limit Carrang Stn

$\mathrm{N}$ limit KNP

$\mathrm{N}$ limit KNP

$\mathrm{N}$ limit KNP

$\mathrm{N}$ limit Kalbarri Area

Presumed extinct Ajana area 
Beyeria cyantescen

Beyeria cyghorum

Beyeria lepidopetala

Beyeria similis

Calycopeplas marginatus

Euphorbia aff. alsiniflora (ASW 10547)

Euphorbia alsiniflorat

Euphorbia atote

Euphorbia australis stubsp. australis

Eupherbia boophehona

Euphorbia coghlani
Eupherbia drummondit

* Euphorbia drum

Euphorbia kimberleyensis

Euphorbia myrtoides

Euphorbia sharkensis

Eupharbia tarnensis subsp. eremophita

Monotaxis gracills

Monotaxis grandifora

Monotaxis larida

Phyllanthus calveinus

Phyllanthus fuernohri

phyllanthus lacunellus

Phyllanthus maderaspatensis

Phyllanthus maillandianus

Phyllanthus sp. (ME Trudgen 7563)

Poranthera microphylla

Pseludanthus intricatus $\mathrm{ms}$

Ricinocarpos ghaucus

Ricinocarpos muricatus

* Ricinus communis

Sauropus crassifolius

Stachystemon sp. (S. Van Leeuwen 210)

rankeniaceae

Frankenia ambita

Frankenia cinerea

Frankenia confusat

Frankenta laxiftora

$N$ limit ZNP

$N$ limit Tamala Stn

$S$ limit DHI

N limit Nanga Stn.

Endemic WHA

N limit ZNP

$S$ limit KNP

\section{S limit DHI}


Frankenia pauciflor

Frankenia setosa

KNP

Gentianaceae

* Centaurium erythraea

Centaurium spicatum

* Centaurium tenuiflorum

Geraniaceae

Erodium angustilobum

* Erodium aureum

* Erodium cicutarium

Erodium crinitum

Erodium cygnorum subsp. cygnorum

Pelargonium littorale

$\mathrm{N}$ limit ZNP

Goodeniaceae

Brunonia australis

Dampiera altissima

Dampiera haematotricha subsp. dura

Dampiera incana var. fuscescens

Dampiera incana var incana

Dampiera krauseana

Dampiera lindleyi

Dampiera oligophylla

Dampiera spicigera

Dampiera stenostachya

Dampiera wellsiana

Goodenia aff. havilandii (GJK \& NG 1505)

Goodenia berardiana

Goodenia caerulea

Goodenia corynocarpa

Goodenia drummondii

Goodenia hassallii

Goodenia havilandii

Goodenia maideniana

Goodenia micrantha

Goodenia microptera

Gondenia mimuloides

Goodenia neogoodenia

Goodenia occidentalis

Goodenia ochracea

Goodenia pinnatifida

Goodenia pulchella

Goodenia salmoniana

Goodenia sericostachy

Goodenia tenuiloba

\section{$\mathrm{N}$ limit KNP}

$\mathrm{N}$ limit Meadow Stn.

$\mathrm{N}$ limit Murchison House Stn.

$\mathrm{N}$ limit Tamala Stn.

$\mathrm{N}$ limit KNP

$\mathrm{N}$ limit KNP

$S$ limit Murchison $\mathrm{R}$.

$\mathrm{N}$ limit KNP

$N$ limit KRNP

$S$ limit DHI

N limit KNP

Type only Gascoyne R

$\mathrm{N}$ limit Cobum Stn. 
Lechenaultia floribunda

$N$ limit Eurardy Stn.

$\mathrm{N}$ limit CNR

Lechenaulfia hirsuta

$N$ limit DHIIFPNP

$\mathrm{N}$ limit Meadow Stn.

Lechenturia mucrides

S limit Carrang Sin.

Lechenatha subc vmosa

Pentaptilon careyi

$\mathrm{N}$ limit Coburn Stn.

Scaevola anchusifoh

\section{$\mathrm{N}$ limit KNP}

$N$ IImit WHA

$N$ limit Coral Bay

S limit Tamala Stn

Slimit Tamala Stn

Scaevola crassifolia

Scaevolu dielsii

Scaevola dielsi

Scaevola glandulifera

Scaevola globulifera

Sicatevala hamiltonii

N limit KNP

$N$ limit KNP

Endemic KNP

Scuevola lanceolata

Scaevola nitida

Suevola oldfieldis

Scuevolut aryclona

Scaevola parvifolla subsp. pilbarae

Scaevola phlebopetala

Scaevola porocarya

Scaevola pulchella

Scaevola repens var. erecta ms

Scaevola restiaced

Siaevola sericophylla

Scaevola spinescens

Scaevola thesioides

Scaevola tomento

Symphyobasis macroplectra

Velleia cyonopotamica

Velleia discophora

Velleia glabrata

Velleia hispida

Verreauxia reinwardtii

\section{Gyrostemonaceae}

Codonocarpus cotmifolius

Gyrostemon racemiger

Gyrostemon ramulosu.

Gyrostemon subnudus

Tersomia cyathiftera

$N$ limit Coburn Stn.

$\mathrm{N}$ limit Murchison House Stn N limit KNP

Type only Murchison $\mathrm{R}$.

N limit KNP

N limit VCL S of Tamala Stn

$S$ limit near Carnarvon

S limit Nerren Nerren Stn.

N limit Wooramel R.

N limit KNP

$N$ limit KNP

N limit KNP 


\section{Haemodoraceae}

Anigozanthos humilis subsp. humilis

Anigozanthos kalbarriensi.

Anigozanthos manglesii subsp. quadrans

Conostylis aculeata subsp. echinissima

Consostylis aculeata subsp. rhipidion

Conostylis aculeata subsp. septentrionora

Conostylis androstemm

Conostylis aurea

Conostylis candicans subsp. flavifolia

Conosiylis prolifera

Conostylis resinos

Conostylis robusta

Conostylis stylidioides

Haemodorum brevisepalum

Haemodorum discolor

Haemodorum paniculatum

Haemodorum simulans

Haemodorum spicatum

Tribonanthes australis

Tribonanthes violacea

\section{Haloragaceae}

Glischrocaryon aureum var. angustifolium

Glischrocaryon aureum var aureum

Glischrocaryon flavescens

Code

Gomorisn

$N$ limit KNP

N limit Murchison House Stn

$N$ limit Nanga Stn.

Endemic to Nerren Nerren Area

$N$ limit KNP

Endemic KNP to Tamala Stn.

$\mathrm{N}$ limit KNP

$N$ limit Nanga Stn.

$N$ limit KNP

$N$ limit KNP

$N$ limit KNP

N limit DHI

$N$ limit KNP

$N$ limit KNP

$N$ limit KNP

$\mathrm{N}$ limit KNP

$\mathrm{N}$ limit CNR

$\mathrm{N}$ limit KNP

$N$ limit KNP

$N$ limit KNP

$N$ limit Tamala Stn

$\mathrm{N}$ limit KNP

$N$ limit KNP

$\mathrm{N}$ limit KNP

$\mathrm{N}$ limit KNP

$\mathrm{N}$ limit KNP
Orthrosanthus laxus var. laxus

Patersonia drummondii subsp. borealis ms

Patersonia graminea

Patersania accidentalis

Isoetacea

Isoetes drummondi

Isoetes mueller

Juncaceae

1
1
1
1
1
1
1
1
1
1
1
1
1
1
1

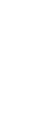


Triglochin calcitrapum
Triglochin centrocespum

Triglochin minutissimum

Triglechin mucronatum
Triglochin trichopherum

Lamiaceae

$$
\begin{aligned}
& \text { Hemiandra pungen.s } \\
& \text { Hemiandra sp. (Beard 7059) }
\end{aligned}
$$

$N$ limit KNP

Endernic WHA

Hemiandra sp (Trudgen sn)

Hemicandra sp. Kalbarri (D) Bellairs 1505)

Endemic WHA

Endemic KNP

Hemigenia diplanthera

$N$ limit KNP

Hemigenia macrantha

N limit Tamala Stn

Hemigenia scabra

Matocorys logamated

Micosorys tenuifolia

Prostanthera albitlora

Prostanthera camploellit

* Salvia verbenaca

Westringia aff dempien (GJK \& NG 798)

Westringia dampie

Westringia rigida

N limit DINR

Lauraceae

Cassytha aurea var. aured

Cassvtha aurea var hirn

Cassytha filiformis

Cassytha flave

Carsytha glabella

Carsytha nodiflora

Cassytha pomiformis

Cassytha racemosa forma pilosa

Cassytha racemosa forma racemosa

N limit Shark Bay

$N$ limit FPNP

$N$ limit FPNP

Lentibulariaceae

Urricularia tenella

N limit KNP

N limit KNP

N limit KNP

Isotoma hypocrateriformis

Lobelia alata

Vlimit KNP

Lobelia heterophylla 
Lobelia rhytidosperma

Lobelia winfridae

$N$ limit KNP

* Monopsis debilis

\section{Loganiaceae}

Logania aff. litoralis (AH Burbidge 4406)

Logania biloba

Logania flaviflora

Logania litoralis

Logania nuda

N limit VCL W of Nerren Nerren Stn

$S$ limit KNP

Logania spermacoced

Phyllangium paradoxum

\section{Loranthaceae}

Amyema benthamii

Amyema fitzgeraldii

Amyema gibberula var gibberula

Amyema hilliana

Amyema linophyllo

Amyema maidenii subsp. maidenii

Amyema melaleucae

Amyema miquelii

Amyema miraculosa subsp. miraculosa

Amyema preissi

Amyema sanguinea var. sanguined

Lysiana casuarinae

Lysiana exocarpi

Lysiana murrayi

Lysiana subfatcato

Nuytsia floribunda

Lythraceae

Ammannia baccifera

Ammannia multiflora

Lythrum sp. Towrana (RJ Cranfield 2183)

Rotala diandra

N limit NW Cape

$S$ limit Wooramel R.

$N$ limit ZNP

S limit Carey Downs Stn. (from Barlee Range)

S limit Carey Downs Stn. (from Rudall R.)

Abutilon aff. oxycarpum (Morat 8145)

Abutilon amplum

Abutilon cryptopetalum

Abutilon exomemum

$S$ limit DINR

Abutilon leucopetalum 
Alyogyne cuneiform

Alyogine hakeifolis

Alyogyne huegetii var. glossulariuefolius ms

Alyogyne huegelii var. huegelii $\mathrm{ms}$

Alyogyne huegehi var. wrayae ms

Alyogyne pinoniana var. leptochlamys

Alyogyne pinomiana var. pinomiana

Gossypium australe

Hibiscus brachychlaenus

Hibiscus burtonii

Hibiscus coatesii

Hibiscus drummondii

Hibiscus gardnerii m

Hibiscus leptocladus

Hibiscus sturtii var. grandifforus

Hibiscus sturtii var, truncatu

* Lavatera cretica

Lavatera plebeia var tomentosa

Lawrencia densiflora

Lawrencia glomerat

Lawrencia sp Mulein Station (Setter 317)

Lawrencia spicata

Lawrencia viridigrisea

* Malva parviflera

Malvastrum americanam

Sida aff. intricata (GJK \& NG 11.34)

Sida calyxhymenia

Sida corrugata

Sida fibulifera

Sida filiformis

Sida intricata

Sida kingii

Sida platycalyx

Sida rohlenae

Sida sp. Carnarvon (P.S. Shor 2492

Sida sp. Pindar (A. Mitchell 3585)

Sida sp. unisexual (N. H. Speck 574)

\section{Marsileaceae}

Marsilea angustifolim

Marsilea drummondii

Marsilea exarata

N limit Tamala Stn

Marsilea hirsuta

Menyanthaceae

Villarsia congestiflora 


\section{Mimosaceae}

Acacia aciphylla

Acacia acuaria

$\mathrm{N}$ limit KNP

Acacia acuminate

$N$ limit TNR

Acacia amblyophylla

Endemic WHA

Acacia ampliceps

Acacia ancistrocarpa

Acacia andrewsii

Acacia aneura

$\mathrm{N}$ limit ZNP

Acacia ashbyae

$\mathrm{N}$ limit KNP

Acacia bidentata

$N$ limit KNP

Acacia bivenosa

Acacta blakelyi

Acacia cavealis ms

Acacia chartacea

Acacia citrinoviridi.

Acacia cochlearis

Acacia comans

Acacia coolgardiensis subsp. coolgardiensis

Acacia coolgardiensis subsp. effusa

Acacia coriacea subsp. coriaced

Acacia coriacea subsp. penden.

Acacia cuspidifolia

Acacia cuthbertsonii subsp. cuthbertsonii

Acacia didyma

N limit Tamala Stn

N limit Murchison House Stn.

Acacia drepanophylla

Acacia ericifolia

Acacia farnesiana

Acacia galeata

Acacia gelasina

Acacia grasbyi

Acacia gregorii

Acacia inaequilatera

Acacia isoneura subsp nimia ms

Acacia kempeana

Acacia lasiocarpa var lasiocarpa

Acacia latipes subsp. latipes ms

Acacia leptospermoides subsp. leptospermoides

Acacia leptospermoides subsp. obovata

Acacia ligulata

Acacia ligustrina

$N$ limit KNP

S limit Wooramel R

Endemic Shark Bay \& DHI

Endemic Carbla Stn. area

$\mathrm{N}$ limit Murchison House Stn.

N limit Nerren Nerren Stn. 
Acacia neurophylla subsp. crugata

$\mathrm{N}$ limit CNR

Acacia oldfieldir

$N$ limit KNP
$N$ limit KNP

Acacian ary

Acacta palustris

Acacia plautella ms

Acacia pruinercarpe

Accicia puncticulata ins

Acacia pyrifolia

Acacia quadrimargine

Acacia quadrisulcata

Acacia ramulasa

Acucia restiacea

Acacia rhodophloia

Acacia restellifera

Acacia raycei

Acacia sabulosa ms

Acacia saligna

Acacia saxatilis

Acocias scirnifolic

Acacia sclerosperma subsp. glaucescens

Acacia sclerosperma subsp. sclerosperma

Acacia sexsilts

Acacia signala

Acacia sp. (KRN 11816 )

Acacia spathulifolia

Acacia sphenophylla ms

Acacia stereophylla var cylindrata

Acacia sherem phy var cylindrata

har stereophylla

Acacia subrigida

Acacia subtessarogona

Acacia synchroniciat

Acacie tetragonaphylla

Acacia ulicina

Acacia victoriat

Acacia wany

Acacte wiseuna

Acacta xanthina

Acacia xiphophylla

* Neptunia dimorp

N limit ZNP

N limit KNP

N limit Hamelin Stn.

N limit KNP

Nlimit KNP

N limit Yaringa Stn

N limit KNP

$\mathrm{N}$ limit Eurardy Stn

N limit CNR

$\mathrm{N}$ limit CNR

N limit Nerren Nerren Stn.

N limit Tamala Sin.

\section{N limit KNP}

N limit Tamala Stn

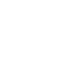


Molluginaceae

Glinus lotoides

Macarthuria australis

Macarthuria georgeana

Macarthuria intricata

$N$ limit Tamala Stn.

N limit Nanga Stn.

Moraceae

Ficus platypoda var. lachnocaulos

Ficus platypoda var. minor

\section{Myoporaceae}

Eremophila clarkei

Eremophila compacta subsp. compacto

Eremophila crenulata ms

Eremophila cuneata $\mathrm{m}$

Eremophila cuneifolia

Eremophila decipiens subsp. decipiens $\mathrm{ms}$

Eremophila deserti

Eremophila exilifolia

Eremophila flaccida ms

Eremophila forrestii

Eremophila fraseri subsp. fraseri $\mathrm{ms}$

Eremophila fraseri subsp. parva $\mathrm{ms}$

Eremophila freelingi

Eremophila gibsonii

Eremophila glabra

Eremophila glabra subsp. Zuytdorp (GJK \& NG 518)

Eremophila glabra subsp. albicans

Eremophila glabra subsp. carnosa ms

Eremophila glabra subsp. psammophora ms

Eremophila glabra subsp. tomentosa ms

Eremophila glutinosa

Eremophila granitica

Eremophila lanata $\mathrm{ms}$

Eremophila latrobei subsp. latrobei $\mathrm{ms}$

Eremophila leucophylla

Eremophila longifolia

Eremophila mackinlayi subsp. mackinlayi ms

Eremophila mackinlayi subsp. spathulata ms

Eremophila maculata subsp. brevifolia $\mathrm{ms}$

Eremophila maitlandi

Endemic WHA

Ereckinlayi $\mathrm{ms}$

Eremophila microtheca

Eremophila occidens ms

Eremophila oldfieldii subsp. oldfieldi

Eremophila oppositifolia

Eremophila pantonii 
Eremophilasplendens ms

Endemic WHA

Eremophila spuria ms
Eremophila strongylophylla

Eremophila subflociosd

Eremophila youngii subsp. youngii ms

Myoporam acuminatum

Myoporum insulare

Myoporum montanum

Myrtaceae

Baeckea blackallis ms

Baeckea margarethae m

Baeckea megaftora ms

Baeckea pentagonantha

Bueckea robusta

Baeckea sp. 38 (M.E Trudgen 7180)

Baeckea sp. Murchison River (S.D.Hopper 1428)

Baeckea sp. Mingenew (M.E.Trudgen 12029)

Baeckea sp. Nanga (A.S.George 11346)

Baeckea subcuneata

Beaufortia dampier

Beaufortia elegans

Beaufortia squarrosa

Callistemon phoreniceus

Calothamnus blepharospermus

Calothamnus borealis

Calothamnus chryantherus

Calothamnus formosus subsp. formosus

Calothamnus glaber ms

Calothamnus homalophyllus

Calothamnus kalbarriensis

Calothamnus oldfieldii

Calothamnus pachystachyus

Calothamnus quadrifidus

Calytrix brevifolia

Calytrix depressa

Calytrix desolata

Calytrix drummondi

Calytrix ecalycata

Calytrix formosa

Calytrix fraseri

Calytrix glutinosa

Calytrix gracilis

$\mathrm{N}$ limit Coburn Stn.

$\mathrm{N}$ limit Tamala Stn

$\mathrm{N}$ limit CNR

$\mathrm{N}$ limit WHA Stn.

$\mathrm{N}$ limit DINR

$N$ limit KNP

$\mathrm{N}$ limit KNP

$\mathrm{N}$ limit Tamala Stn

Endemic WHA

$\mathrm{N}$ limit Nanga Stn.

$\mathrm{N}$ limit Tamala Stn

$\mathrm{N}$ limit Eurardy Stn

$\mathrm{N}$ limit KNP

N limit Nanga Stn.

$\mathrm{N}$ limit Tamala Stn

$\mathrm{N}$ limit KNP

$\mathrm{N}$ limit KNP

$N$ limit KNP

$\mathrm{N}$ limit KNP 
Calytrix harvestiana

Calytrix leschenaulit

Calyrix oldfiedd

Calytrix paucicostata

Calytrix purpurea

KNP

TNR

Calytrix sapphirin

$\mathrm{N}$ limit CNR

Calytrix strigosa

Endemic Kalbarri Area

Endemic Kalbarri Area

$\mathrm{N}$ limit KNP

Calytrix truncatifolia

$N$ limit DHI

Chamelaucium brevifolium

Chamelaucium conostigmum $\mathrm{ms}$

N limit KNP

Chamelaucium marchamin

Endemic Kalbarri Area

Chamelaucium micranthum

Chamelaucium oenum hum

$N$ limit ZNP

Chamelaucium pauciflorum subsp. pauciflorum ms

Chamelaucium sp. Coolcalalaya (A.H.Burbidge 4233)

Chamelaucium uncinatum

$N$ limit KNP

Chamelaucium vinosum $\mathrm{ms}$

Conothamnus trinervis

Darwinia capitellata

Darwinia oldfieldii

Darwinia paciflora

Darwinia virescens

Eremaea acutifolia

Eremaea dendroidea

$\mathrm{N}$ limit Murchison House Stn

$\mathrm{N}$ limit Tamala Stn.

$N$ limit KNP

Endemic Kalbarri Area

N limit KNP

N limit KNP

Eremuea ebracteata

$\mathrm{N}$ limit Nanga Stn.

Eucalyptus aff, prominens (MIH Brooker 4569)

limit Tamala Stn

Eucalyptus camaldulensis var. obtusa

1

Eucalyptus dichromophloia

Eucalyptus diminuta ms

Eucalyptus dolichocera

Eucalyptus drummondi

Eucalyptus eudesmioides subsp. eudesmioides

Eucalyptus eudesmioides subsp. pallida $\mathrm{ms}$

Eucalyptus eudesmioides subsp. sellachiana ms

Eucalyptus flocktoniae

Eucalyptus foecunda subsp. Coolimba (M.1.H.Brooker 9556)3

Eucalyptus fruticosa

Eucalyptus gittinsii

Eucalyptus hypochlamydea subsp. hypochlamydea $\mathrm{ms}$

Eucalyptus jucunda

Eucalyptus kochii

Eucalyptus lenziana

\section{N limit ZNP}

N limit Towarana Stn

Endemic WHA

$\mathrm{N}$ limit KNP

$S$ limit KNP

N limit Nanga Stn

$\mathrm{N}$ limit CNR/Coburn Stn 
Eucalyptus rigidula

Endemic WHA

Eucalypas roycet

Eucalypus striaticalyx

Eucalyptus subangusta subsp. pusilla

Eucalyptus transciontinentalis

Eucalyptus victrix

Homalocalyx aff. aured

Homalocalyx aureus

Hypocalymma longifolium

Lamarchea hakeifolia var. brevifolia

Lumarchea hake ifolio var hakeifulio

Malleostemon hursthouse

Malleostemon minilicaensis

Malleostemon pedunculatus

Malleostemon pehiger

Malleostemon roseus

Mallestemon sp Nerren Nerren (Payne 360)

Malleostemon sp. Maadow Station (A.H.Burbidge site 69)

Malleostemon sp. Rabbit Proof Fence (A. H. Burbidge site 59)

Malleastemon sp. Cooloomia (S.D.Hopper 1353)

Malleostemon sp. Hardabutt Rapids (D.Bellairs 1654A)

Malleostemon sp Kalbarri (L A Craven 7083)

Malleostemon sp. Kalbarri (L.A.Craven 7083)
Malleostemon sp. Moonyoonooka (R.J.Cranfield 2947)

Malleastemon tuberculatu

Melaleuca acersis

Melaleuca adnata

Melaleuca aff leiopyxis (GJK \& NG 1708)

Melaleuca aff. eremaea (GJK \& NG 1332)

Melateuca aff holoserices

Melaleuca aff, nesophila (AHB 4520)

Melaleuca aff. oldfieldiinnesophylla (Beard 6768)

Melaleuca aff. oldfieldii (C. Gardner 13412)

Melaleuca calothamnoides

Melaleuca cardiophy tha

Melaleuca ciliosid

Melaleuca concreta

Melalewa conothamnoides

Melalenca cordata

Melaleaca depressa

Melaleuca eleuterostachy

N limi KNP

$N$ limit KNP

N limit Nerren Nerren Stn.

Endemic WHA

$\mathrm{N}$ limit Coburn Stn.

$N$ limit Carrang Stn

$\mathrm{N}$ limit Coburn Stn.

Endemic Nerren Nerren Stn

Endernic WHA

N limit KNP

$N$ limit Tamala Stn

Melaleuca eremate

Endemic WHA

Endemic WHA

Endemic Kalbarri - Murchison House Stn.

$\mathrm{N}$ limit KNP

Endemic Kalbarri Area

$N$ limit KNP 
Melaleuca glomerata

Melaleuca holosericea
Melaleuca huegelii subsp. pristicensis

Melaleuca huegelit subsp. pristicensts
Melaleuca lanceolata subsp. occidentalis

Melaleuca lanceolata

Melaleuca lasiandra
Melaleuca lateriftora subsp. acutifolia ms

Melaleuca lateritia

Melaleuca laxiflora

Melaleuca leiopyxis

Melaleuca leucadendra

Melaleuca leucadendra

Melateuca linophylla

Melaleuca megacephala

Melaleuca nematophylla

Melaleuca oldfieldii

Melaleuca psammophila.

Melaleuca radula

Melaleuca rhaphiophylla

Melaleuca scabra sen. lat.

Melaleuca sp. (Trudgen $\mathrm{sn}$ )

Melaleuca subtrigona

Melateuca trichophylla

Melaleuca uncinata

Melaleuca undulata

Melaleuca urceolaris

Melaleuca viminea subsp. viminea

$\mathrm{N}$ limit DHI

Endemic WHA

$\mathrm{N}$ limit DHI

$\mathrm{N}$ limit KNP

N limit Nanga Stn.

$N$ limit KNP

$\mathrm{N}$ limit KNP

Endemic WHA

N limit Carrang Stn
$\mathrm{N}$ limit Coburn Stn.

$\mathrm{N}$ limit ZNP

$S$ limit Hamelin Stn

Endemic Kalbarri Area
Endemic Murchison House Stn.

Phymatocarpus porphyrocephalus

Pileanthus aff. filifolius (Bellairs 1684)

Pileanthus aff. peduncularis (Hopper 1385)

Pileanthus auranticus ms

Pileanthus bellus $\mathrm{ms}$

Pileanthus limacis

Pileanthus peduncularis

Pileanthus peduncularis
Pileanthus septentrionalis (ML 2492)

Pileanthus vernicosus

Scholtzia cordata ms

Scholtzia leptantha

Scholtzia sp. Coolcalalaya (A.H.Burbidge sn)

Scholtzia sp. Ajana (T.A.Halliday 137)

Scholtzia sp. East Yuna (A.C.Burns 6)

Scholtzia sp. Eurardy (J.S.Beard 6886)

Scholtzia sp. Folly Hill (M.E.Trudgen 12097)

Scholtzia sp. Galena (W.E.Blackall 4728)

Scholtzia sp. Kalbarri (N.Hoyle 623) 
Sinotria sp. Ross Graham Lookout (S.Maley 6)

Scholtzic sp. Shark Bay (MET 7429)

Schoftrat sp. Z-Bend (Bellairs-Kalflora 912a)

N limit Nanga Stn

Sichohtiat spatulata

Scholtzia uberiford

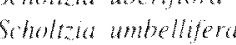

Thrypomene aspert ssp. glabra MS

Thryptomene baecketicet

Thryptomene decussata

Throptomene denticulata

Throptomene mucromuldu

Throptumene numphanenis ms

Throptomene prolifers

Thryotumene racemulosa

Thryptomene sp. Kalbarri (A. Ginness 2378

Throptomene sp. Wandana (A.H.Burbidge site 13 Thryptomene sp. Carrarang(M.E.Trudgen 7420)

Thryptmene sp. Eagle Gorge(A.G.Gunness 2360)

Thryptomene sp. Eurardy(D.\& B Bellairs)

Throptomente sp. Junga Dam(A G Gunness 2383 A

Unness $2383 \mathrm{~A}$

Thrypumene sp. Sicep Pan A G Guness 2383A)

Thryptomene sp Tamala(M E

Thrymomene stowhylla

Thryptomene strongylophylla

Throptomene suromglophylla subsp. Tambla (MET Tudec 7384)

Verticordia copillaris

Verticorda chrvisatha

Verticordia chrysostachys var. chrosestachys

Verticordia cooloomita

Verticordia dasystylis subsp kalbarriensis

Vericordia densiffora var. roseostella

Verticordia densiffora var. stellutigera

Verticordia dictroma var. dichrema

Verticordia dichroma var. sintoma

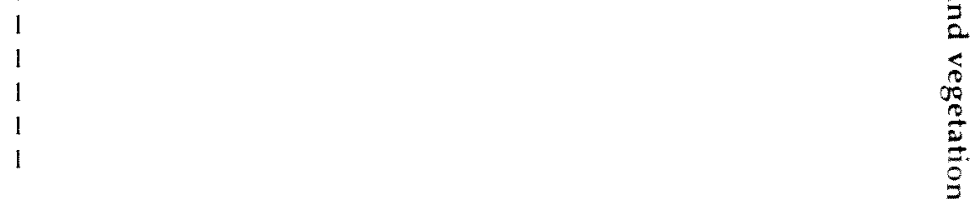

Verticerdia entrephala

Vericordia etheliana var. etheliana

Verticordia etheliana var formesa

Vericordia forresti

Verticordia galeata

Verticordia meriari

limit Coburn Stn.

N limit CNR

N limit Coburn Stn

Endemic WHA

Endemic KNP to ZNP

Endemic WHA

$N$ limit CNR

Endemic WHA

Endemic WHA

$N$ limit Coburn/Meadow Stn.

$N$ limit CNR

$N$ limit VCL S of Tamala Stn

Vericicurdia lepiduphylla var lepidophy tha

Verticordia lepidophylla var. quantula

Verticordia monadelpha var. callitricha

1

Verticordina

Verticordia pennigeta

Verticordia pholidophylla 
Verticordia picta

$\mathrm{N}$ limit CNR

Verticordia spicata subsp. spicata

\section{Najadaceae}

Najas marina

\section{Nyctaginaceae}

Boerhavia burbidgeana

S limit Carnarvon

Boerhavia coccinea

Boerhavia gardner

Boerhavia repanda

Boerhavia schomburgkiana

Commicarpus australis

Olacaceae

Olax aurantia

$S$ limit KNP

$S$ limit Carrang Stn

Jasminum calcarium

Jasminum sp. (B. Turner 1)

Ophioglossaceae

Ophioglossum gramineum

Ophioglossum lusitanicum

\section{Orchidaceae}

Caladenia bicalliata

Caladenia bryceana subsp. cracens ms

Caladenia discoidea

Caladenia drummondii

Caladenia flava subsp. maculata ms

Caladenia hirta subsp. rosea ms

Caladenia hoffmanii ms

Caladenia incensa ms

Caladenia latifolia

Caladenia longicauda subsp. borealis $\mathrm{ms}$

Caladenia pachychila ms

Caladenia reptans subsp. impensa $\mathrm{ms}$

Caladenia reptans subsp. reptans $\mathrm{ms}$

Caladenia roei

Caladenia varians ms

Caladenia varians subsp. nobilis $\mathrm{ms}$

rians subsp. varians ms

Caladenia wanosa

Cyanicula amplexans $\mathrm{ms}$

Cyanicula deformis ms
N limit KNP

$N$ limit KNP

$N$ limit KNP

$\mathrm{N}$ limit KNP

$N$ limit KNP

Endemic KNP

$\mathrm{N}$ limit KNP

$\mathrm{N}$ limit KNP

N limit Kalbarri Area 
Drakomirchis barbarella ms

Elythranthera brunonis

$\mathrm{N}$ limit KNP

Elvthranthera emarginuta

$\mathrm{N}$ limit KNP

$\mathrm{N}$ limit Tamala Stn

Eriochilus dilatatus subsp. dilatatus ms

Eriochilus dilatatus subsp. undulatus ms

$\mathrm{N}$ limit Tama

Leporella fimbriata

Microtis media subsp. media

Paracaleana lyonsii ms

Paracaleana terminalis ms

Prasophyllum calcicola ins

Prasophyllum syphochilum

Endemic TNR - Nerren Nerren Stn.

$\mathrm{N}$ limit KNP

$\mathrm{N}$ limit KNP

Prasophyllum elatum

Prasophyllum giganteum

Prasophyllum gracile

Prasophyllum ringens

Prasophyllum sargenti

Pterostylis aff. nana (GJK \& NG 1867

Pterostylis aspera

Pterostylis nama

Pterostylis picta

Pterostylis sanguinea

Pterostyls sangutned

Pterostyles scabra
Pyrorchis nigricans

Sprerculaed ciliate

Spiculaea ciliata

Thelymitra campanulata

Thelymitra flexuesa

Thelymitra sargenti

Thelymitra spiralis

\section{Orobanchaceae}

Orobanche minor var. australiana

\section{Oxalidaceae}

Oxalis perennans

* Oxalis pes-caprae

Papaveraceae

* Argemone ochroleuca

\section{Papilionaceae}

$\mathrm{N}$ limit KNP

$N$ limit Tamala Stn

$\mathrm{N}$ limit KNP

$N$ limit KNP

$\mathrm{N}$ limit KNP

$\mathrm{N}$ limit KNP

$\mathrm{N}$ limit KNP 
Bossiaea eriocarpa

Code

Brachysema macrocarpum

Chorizema ericifolium

Chorizema racemosum

Clianthus formosus

Crotalaria cunninghamii

Cullen cinereum

Cullen leucanthum $\mathrm{ms}$

Cullen patens

Daviesia divaricata

Daviesia hakeoides subsp. hakeoides

Daviesia intricata

Daviesia nudiflora subsp. nudiflora

Daviesia pedunculata

Daviesia podophylla

Daviesia ramosissima

Gastrolobium bennettsianum

Gastrolobium oxylobioides

Glycine canescens

Glycine clandestina

Glycine tabacina

Glycyrrhiza acanthocarpo

Gompholobium sp. Kalbarri (M.D. Crisp 6300)

Gompholobium tomentosum

Indigofera australis

Indigofera boviperda

Indigofera brevidens

Indigofera colutea

Indigofera george

Indigofera george

Indigofera linifoli

Indigofera monophylla

Indigofera occidentalis $\mathrm{ms}$

Indigofera sp. (KRN 11615)

Isotropis cuneifolia

Jacksonia aff. spinosa (R.J. Cranfield 2576)

Jacksonia angulato

Jacksomia arenicola ms

Jacksonia arida ms

Jacksonia calcicola ms

Jacksonia cupulifera

Jacksonia foliosa

Jacksonia hakeoides

Jacksonia rigida ms

N limit Murchison House Stn.

$\mathrm{N}$ limit KNP

N limit Murchison House Stn.

$N$ limit KNP

$\mathrm{N}$ limit KNP

Endemic Kalbarri Are

N limit Tamala Stn

N limit Nanga Stn.

Endemic Carnarvon Area

$N$ limit TNR

N limit Nerren Nerren Stn.

$\mathrm{N}$ limit KNP

$\mathrm{N}$ limit KNP

$\mathrm{N}$ limit KNP 
Leprosemat dunieswioses

$\mathrm{N}$ limit Kalbarri Area

Leprosema macrocarpum ins

Endemic NW Cape to Shark Bay

Leptosemat tomentosit ms

Endemic NW

Lotus stuentus:

* Lupinar cosentinit

* Medicago polymorpho

* Medicago truncatula

* Melilotus indicus

Mirbelici aff. ramulosa (GJK \& NG 2059)

Mirbelit aff. viminatis (AHB sn)

Mirbelia depressa

Mirbelice ramulessa

Mirbelit sp. (Blackall 556)

Mirbelia sp. Zuytdorp (GJK \& NG 1688)

Mirbelic sp. Denham (W.E. Blackall 556)

Mirbelia sp. Kalbarri (M.D.Crisp 6261)

Mirbelia spinosa

Mirbelia trisheralyx

Muellerimthus trifoliclutus

Nemeia reficulata

Oxylobium lineare

Puttencea dasyphylla

Rhynchosia minima

Sesbania cammabita

Sphaerolobium gracile

Sphaerolobium macranthum

Srylosanthes humitis

Swainsona beaslevana

Swainsona catcicola

Swaninsoma canciscens

Swainsona complanata

Sisainsona comuta

Swainsona ecallosa

Suainsona eleganoides

Swainsona flavicarinatla

Sitainsona gracilts

Swainsona kingii

Swainsona leeanta

Swainsona longicarinata

Swainsona pedunculata

Swainsona perostylis

Swainsona rostellate

Templetonia biloba

Templetonia retusa

$N$ limit TNR

N limit WHA

Endemic Kalbarri Area

N limit Murchison House Stn.

N limit Murchison House Stn.

N limit ZNP

$N$ limit KNP

$N$ limit KNP

$N$ limit KNP

$N$ limit KNP

$S$ limit KNP

Endemic WHA 
Tephrosia flammed

Tephrosia gardner

Tephrosia rosea

Tephrosia sp. (K.R. Newbey 11636)

* Trifolium campestre

Trigonella suavissima

Viminaria juncea

$\mathrm{N}$ limit KNP

Phormiaceae

Dianella revoluta

Stypandra glauca

Pittosporaceae

Billardiera bicolor var lineutu

Billardiera erubescens

Billardiera ringens

Bursaria occidentalis

Cheiranthera filifolia

N limit Tamala Stn.

N limit Nanga Stn.

Cheiranthera preissiana var. preissiana

Pittosporum phylliraeoides var. phylliraeoides

\section{Plantaginaceac}

Plantago aff. hispidula (A.H.Burbidge 4517)

* Plantago coronopus

Plantago debilis

Plantago drummondi

Plantago sp. Mt. Magnet (A.S. George 6793)

Plumbaginaceae

Muellerolimon salicorniaceum

* Aira caryophyllea

Amphipogon caricinus

Amphipogon strictus

Amphipogon turbinatus

Aristida anthoxanthoides

Aristida contorta

Aristida holathera var. holathera

Astrebla elymoides

Astrebla pectinata

Austrostipa compressa

Austrostipa crinita

Austrostipa elegantissima

Austrostipa macalpinei

Austrostipa nitida

Austrostipa tenuifolia 
* Avena fauta

* Avena steritis

* Briza maxima

* Briza minor

Bromus arenarias

* Bromas diandras

* Bromus hordeaceus

* Bromus japonicas

* Bromus madriensis

* Brmas rigidus

* Cenchras ciliaris

* Cenchras echinama

*enchrus setiger
Chloris lobata

Chloris pectituta

Chloris pumiles

* Chloris virgate

Chrysopogen fallax

Chrvsopogens sp Zuytdorn (CJK \& NG 906)

Cymbopogon ambiguus

Cymbapogen bambycints.

Cymbapogion obtectu

Cnodon dactylon

* Dactyloctenitam sustrale

Dactyloctenium radulans

Danthomia ciespitosa

Endemic to ZNP

Danthonia racemosa

Dichanthium sericeum subsp. humilius

Digitaria brownii

Digitaria ctenantha

Diplachne fusca

Diplactne muelleri

Diplachne pariflera

* Ehrharta brevifolits

* Ehrharta calycina

* Ehrharta longiflor

* Eleasine indica

Enneapogon caerulescens

Enneapogon polyphyllus

Enteropogon acicularis

Eragrostis australasio

Eragrostis barrelieri 
Eragrostis browni

Eragrostis cumingii

* Eragrostis curvula

Eragrostis dielsii

Eragrostis elongata

Eragrostis eriopoda

Eragrostis falcata

Eragrostis lanipes

Eragrostis teptocarpa

Eragrostis pergracilis

Eragrostis setifolia

Eragrostis tenellula

Eragrostis xerophila

Eriachne aristidea

Eriachne avenaced

Eriachne benthamii

Eriachne flaccida

Eriachne gardner

Eriachne helmsii

Eriachne lanata

Eriachne mucronata

Eriachne obtusa

Eriachne wata

Eriachne pulchella subsp. dominii

Eriachne pulchella subsp. pulchella

Eriochloa australiensis

Erischloa procera

Eriochloa pseudoacrotricha

Eulalia aurea

Eulalia fulva

* Hordeum geniculatum

* Hordeum leporinum

Iseilema eremaeum

Iseilema membranaceum

Iseilema vaginiflorum

Lamarckia aurea

Leptochloa digitata

* Lolium perenne

* Lolium rigidum

* Lophochloa pumila

Monachather paradoxus

Neurachne alopecuroidea

Panicum australiense

Panicum decompositum

Panicum effusum

Paractaenum novae-hollandiae

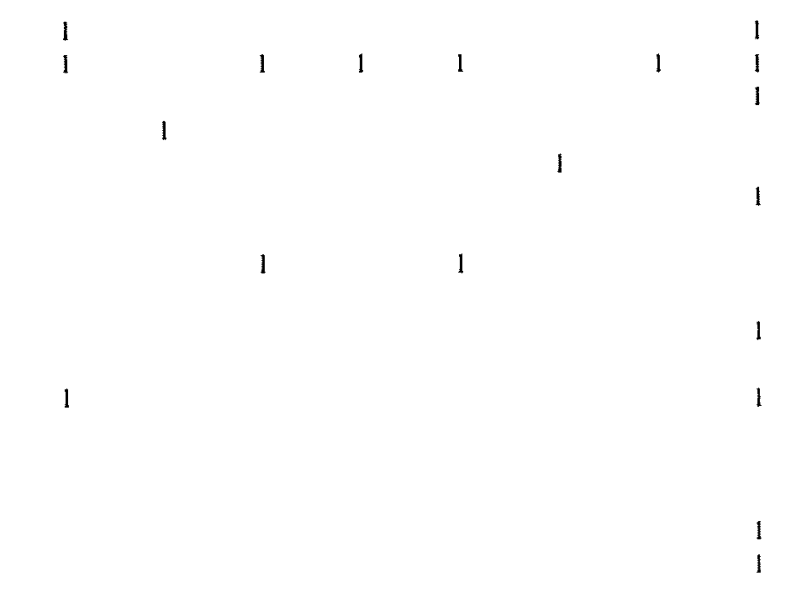


Paspalidium constrictum

Paspalidium gracile.

Paspalidium jubiflorum

Paspalidium re

* Pentaschistis airesides

Perotis rara

* Phalaris minor

Plagiosetum refractam

Plectrachne bromoides

Plectrachne danthonioides

Plectrachne dielsii

Plectrachne drummundii

Plectracthe drammon

Plectrache melvillet

Plectrachne rigidissin

* Plectrachne schinzil

Posa drummondiana

* Polypogon monspeliensis

Psammagrostis wiseana

* Restraria cristata

* Restraria pumila

* Schismus arrabicus

* Schismus arabicus

Schismus barha

Setaria surgens.

* Setaria verticillata

Sorghum plumosum

Spinifex longifolius

Sporobolus actinocladus

Sporobolus blakei

Sporobolus caroli

Sporobolus mitchellit

Sporrolus minthetlu

Sporobolus virgumic

Themeda trandra

Thyridolepis mitchelliana

Tragus australianus

Triodia aff. basedowii

Triodia basedonit

Triodia epactia

Triodia irritans.

Triodia lanigera

Triodia plurinerout

Trisdia plarimerva

Trodia pungen

Triodia scanosa

Triodia tritticondes

Tripogon Lolifformis

$\mathrm{N}$ limit Tamala Stn

$\mathrm{N}$ limit FPNP

$\mathrm{N}$ limit Nanga Stn. 
Triraphis mollis

* Trisetaria cristata

Urochloa gilesii

Urochloa piligera

* Vulpia myuros

Yakirra australiensis

Polygalaceae

\section{Comesperma acerosum}

Comesperma calymega

Comesperma integerrimum

Comesperma polygaloides

Comesperma scoparium

Polygala isingii

\section{Polygonaceae}

Emex australis

Muehlenbeckia adpressa

Muehlenbeckia cunninghami

Rumex crystallinus

* Rumex vesicarius

$\begin{array}{ll}3 & \text { N limit KNP } \\ \text { N limit KNP } \\ \text { N limit ZNP } \\ \text { N limit Tamala Stn. }\end{array}$

Portulacaceae

Calandrinia aff. pumila (Andeberg 206)

Calandrinia calyptrata

Calandrinia corrigioloides

Calandrinia disperma

Calandrinia eremuea

Calandrinia granulifera

Calandrinia lehmannii

Calandrinia liniflora

Calandrinia papillata

Calandrinia polyandra

Calandrinia polypetala

Calandrinia primuliflora

Calandrinia ptychosperma

Calandrinia pumila

Calandrinia remota

$N$ limit ZNP

Calandrinia sp. Coolcalalaya (GJK \& NG 698)
Calandrinia sp. Shark Bay (J.J. Alford 1376)

Calandrinia sp. (GJK \& NG 1495)

Calandrinia stagnensis

Portulaca oleracea

Endemic Carnarvon Basin

$\mathrm{N}$ limit FPNP

Posidonia angustifolia

Posidonia australi

Endemic WHA 


\section{Primulaceae}

* Anagallis arvensir var anensis

* Anagallis anensis var caeruled

Samolus junceus

Samolus repens var. floribundus

Samolus repens var. paucifolius

Samolus sp. Shark Bay (M.E.Trudgen 7410)

$N$ limit FPNP

$S$ limit Hamelin Str.

Proteaceae

Adenanthos acanthophyllus

Adenanthes cyenorum

Bankrias attenuate

Banksia lemtophylla var mellitica

Banksia lindlevan

Banksia menziesi

Banksia priontere.

Banksia sceptrum

Banksitu wionicle

Conospermum acerosum subsp. hirsutum

Conospermum boreale subsp boreale

Conospermum microflorum

Conospermum stoechadis subsp. stoechatis

Dryandra aff, ashbyi (GJK \& NG 1571)

Dryandra borealis subsp. borealis

Dryandra fraseri

Dryandra sesstis

Grevillea aff stenobotrya (MET 7554)

Grevillea annulifera

Grevillea argyrophylla

Grevillea biformis subsp. biformi

Grevillea brachystachya

Grevillea candelabroides

Grevillea candicans

Grevillea commutat

Grevillea costata

Grevillea didymobotrya subsp. didymobotrya

Grevilles dielsiana

Grevillea eriostachy

Grevillea gordonian
Endemic to WHA

$\mathrm{N}$ limit KNP

$N$ limit ZNP

Nlimit KNP

$N$ limit Tamala Stn

$N$ limit Tamala Stn.

$N$ limit Nanga Stn

$N$ limit ZNP

$N$ limit KNP

Endemic Kalbarri Area

$N$ limit Nanga Stn.

N limit Tamola StI.

Endemic Murchison House Stn. to Zuytdorp

S limit Tamala Stn

$\mathrm{N}$ limit WHA

$N$ limit Tamala Stn

$N$ limit KNP

$N$ limit ZNP

$N$ limit FPNP

$N$ limit Nerren Nerren Str

Endemic lower Murchison R.

Endemic lower Murchison
$N$ limit Nerren Nerren Stn.

$N$ limit $C N R$ 
Grevillea hakerides subsp. stenophylla

Grevillea intricata

Grevillea leptopoda

Grevillea leucoclada

Grevillea leucopteris

Grevillea levis

Grevillea obliquistigmo subsp abliquistigma

Grevillea paradoxa

Grevillea petrophiloide

Grevillea pinaster

Grevillea preissii

Grevillea pterosperma

Grevillea rogersoniana

Grevillea sp. Shark Bay (MET 7553)

Grevillea stenobotrya

Grevillea stenomera

Grevillea stenostachya

Grevillea trachytheca

Grevillea triloba

Grevillea variffolia subsp. bunderra ms

Grevillea vestita subsp. isopogoides

Hakea arida

Hakea bucculenta

Hakea candolleano

Hakea circumalat

Hakea coriacea

Hakea costata

Hakea incrassata

Hakea kippistiana

Hakea lissocarpha

Hakea orthorrhyncha

Hakea preissii

Hakea pycnoneura

Hakea recurva

Hakea stenocarpa

Hakea stenophylla

Hakea suberea

Hakea trifurcata

Isopogon divergens

Persoonia acicularis

Persoonia angustiflora

Persoonia biglandulosa

Persoonia bowgada

Persoonia brachystylis

Persoonia hexagona

Persoonia papillosa

Persoonia rufiflor
$N$ limit DHI

N limit KNP

$N$ limit KNP

$N$ limit TNR

$N$ limit ZNP

$N$ limit KNP

$N$ limit KNP

$N$ limit KNP

$N$ limit ZNP

$N$ limit ZNP

Endemic Shark Bay - Tamala Stn.

Endemic to WHA

Endemic KNP to Tamala

$\mathrm{N}$ limit Coburn Stn.

Endemic Kalbarri Area

$\mathrm{N}$ limit KNP

S limit Lake McLeod

$\mathrm{N}$ limit KNP

$\mathrm{N}$ limit CNR/TNR

$\mathrm{N}$ limit KNP

$\mathrm{N}$ limit Tamala Stn.

$\mathrm{N}$ limit KNP

N limit Murchison House Stn.

N limit KNP

$\mathrm{N}$ limit ZNP

N limit Nanga Stn.

$\mathrm{N}$ limit CNR

N limit Nanga Stn

$\mathrm{N}$ limit CNR

$\mathrm{N}$ limit KNP

$N$ limit KNP

KNP TNR ZNP CNR

1

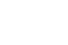


Petrophile semifurcata

$N$ limit Murchison House Stn

$N$ limit KNP

Petrophile semumude

$N$ limit $Z N P$

Petrophle semminda

$N$ limit KNP

$N$ limit KNP

N limit KNP

Nlimit KNP

Stirlingia latifolia

Symaphea rectursa
Sinaphet spintos subsp boredis

$N$ limit KNP

Xylomelum angustifolum

$$
N \text { limit CNR }
$$

S limit KNP

$$
\text { Psilotum nudum }
$$

$N$ limit DHI

Clematis linearitolio

Ranunculus pumilos

Ranunculus sessiliflerus

\section{Restionaceae}

Desmocladus asper ms

Desmeludus hitomis $\mathrm{m}$

Ecdeincolea momostachya

Lepidobolus chaetocephalus

Lepidobolus densus ms

Lepidobohus preissianus

Leptocatpus aristatus

Loxocarya parthenita ms

Lygimia bartsata

Rhamnaceae

Croptandra arbutiflera var boredis

Cryptandra commata

Cryptandra glabriffora

Cryptandra lewophracta

Cryptandra mutila

Cropondra myriamha

Crymandra nudiflora

$N$ limit KNP

N limit Tamala Stn

$N$ limit CNR

$\mathrm{N}$ limit DHI

N limit KNP

$N$ limit KNP

N limit KNP

Crymandra pungen

Croptandra scoporia var microcephala

Cryptandra spyridiotes

Stenanthemum complicatum

Stenanhemum divaricatum

Stenanthemum intricutum

N limit DINR 
Stenanthemum notiale

$\mathrm{N}$ limit ZNP

Stenanthemum pomaderroide

Rubiaceae

Canthium attenuatum

Canthium latifolium

Canthium lineare

Oldenlandia galiondes

Opercularia aff. spermacocea (A.H.Burbidge 4502)

Opercularia spermacocea

Opercularia vaginata

N limit CNR

Synaptantha tillaeacea var. tillaeacea

Rutaceae

Boronia coerulescens subsp. spinescen

Boronia crenulata var. gracilis

Boronia cymosa

Boronia purdieano

Boronia ramosa subsp. anethifolia

Diplolaena geraldtonensis ms

Diplolaena grandiffora

Diplolaena mollis ms

Eriostemon brucei

Eriostemon deserti

Eriostemon sericeus

Eriostemon sp. Kalbarri (GJK \& NG 2034)

Eriostemon tomentellus

Geleznowia verrucosa

Phebalium tuberculosum

talaceae

Anthobolus foveolatus

Choretrum pritzelii

Exocarpos aphyllus

Exocarpos sparteus

Leptomeria preissian

Leptomeria spinosa

Santalum acuminatum

Santalum lanceolatum

Santalum spicatum

Santalum spicatum subsp. nov

N limit Carrang Stn

$N$ limit Hamelin Stn.

$N$ limit Tamala Stn.

$\mathrm{N}$ limit KNP

N limit DHI

$N$ limit DH

Alectryon oleifolius subsp. oleifolius

Diplopeltis eriocarpa

Diplopeltis huegelii var. subintegra

Diplopeltis intermedia var. incana

N limit Nanga Stn.

$S$ limit KNP

Endemic Study area

$N$ limit FPNP

N limit Coburn Sin 
blyophylla

Dodondea inaequifolia

$\mathrm{N}$ limit KNP

Dodonaea larreoside

Dodomaea petiolari

Dodonaea pinifolia

Dedenceea ptarmicaefolia

Dodonaea viscosa subsp. angustissima

Dodonaea viscosa subsp. spatulata

$\mathrm{N}$ limit FPNP

Scrophulariaceae

* Dischisma arenarium

Dischisma arenarium

Elacholoma hornu

Glossostigma diandrum
Glossostigma drummondii

Mimulus gracilis

Mimulus repens

Peplidium aithocheilum

Peplidium muelleri

Peplidium sp. (N.T. Burbidge \& A. Kain 8152)

Stemodia florulenta

Stemodia grossa

Stemodia gressia
Stemodia viscosa

Striga curviftora

Solanaceae

Anthocercis genistoide

Anthocercis ilicifolia subsp. caldariola

Anthocercis ilicifolia subsp. ilicifolia

Anthocercis intricata

Anthocercis sp. Shark Bay (T.E.H. Aplin 3335)

Anthotroche myopornides

Anthotroche myoporndes
Anthotroche walcotii

Anthotroche walcotti

* Daphanthera racemo

Duboisia hopwoodi

Lycium australe

* Lycium ferocissimum

Nicotiana cavicola

* Nicotiana glauca

Nicotiana glauca

Nicotiana occidentalis subsp. hesperis

Nicotiana occidentalis subsp. obliquat

Nicotiana rotundifolia

N limit CNR

$\mathrm{N}$ limit KNP

$\mathrm{N}$ limit WHA

Endemic Cape Cuvier - Tamala Stn

$\mathrm{N}$ limit Meadow Stn.

Nicotiana simulans 
* Solanum americanum Solanum cleistogamum Solunum diversiflorum

Solanum esuriale

Solanum hesperium

Solanum horridum

Solanum lasiophyllum

* Solanum nigrum

Solanum oldfieldii

Solanum orbiculatum subsp. orbiculatum

Solanum phlomoides

Solanum sturtianum

$\mathrm{N}$ limit $\mathrm{S}$ of WHA

Solanum symonii

Stackhousia dielsi

Stackhousia megaloptera

Stackhousia monogyna

Stackhousia muricata

Stackhousia pubescens

Stackhousia viminea

Tripterococcus brunonis

Sterculiaceae

Brachychiton gregorii

Commersonia crispa

Commersonia gaudichaudii

Commersonia melanopetala

Commersonia microphylla

Guichenotia aff. micrantha (Wittwer 1809)

limit KNP

N limit Tamala Stn

Guichenotia ledifolia

Guichenotia macrantha

$N$ limit DHI

Hannafordia quadrivalvis

Keraudrenia hermanniifolia

Keraudrenia integrifolia

Lasiopetalum angustifolium

Lasiopetalum oldfieldii

Lasiopetalum oppositifolium

Rulingia craturophylla

N limit DINR

Rulingia cygnorum

Rulingia densiflora

Rulingia kempeana

Rulingia luteiflora

Rulingia malvifolia var. borealis

Waltheria indica 
Stylidum calcaratum

$N$ limit KNP

$N$ limit Tamala Stn

Stylidium dichosumum

$\mathrm{N}$ limit KNP

Stylidium dispermum

Stylidium ecorne

Stylidium leptophylium

Stylidium limbatum

Stylidium macrocarpum

Stylidium piliferum

Stylidium pubigerum

Stylidium repens.

Stylidium sp Kalbarri (A Carr 145)

$\mathrm{N}$ limit Nerren Nerren Stn./CNR

$\mathrm{N}$ limit KNP

$N$ limit KNP

$\mathrm{N}$ limit CNR

$\mathrm{N}$ limit Tamala Stn

$\mathrm{N}$ limit KNP

$\mathrm{N}$ limit KNP

N limit Tamala Stn.

Stvidium wilroyense

Surianaceae

Stylubasium australe

Stylobasium spathulatum

N limit Murchison House Stn

Tamaricaceae

* Tamarix aphylla

\section{Thelypteridaceae}

Cyclosorus interruptus

Thymelaeaceae

Pimelea ammocharis

Pimelea angustifolia

Pimelea floribunda

Pimelea gilgiana

Pimelea leucantha

Pimelea microcephala subsp. microcephata

Pimelea sessilis

Pimelea sessitus

iaceae

Corchorus crozophorifolius

Corchorus elachocarpus

Corchorus sp. Carnarvon (A.M.Ashby 2321

Corchorus walcottit

Triumfetta sp. T Kimberley Flora

Tremandraceae

Tetratheca hirsuta

Typhaceae

Typha domingensis

\section{Timit KNP}

$\mathrm{N}$ limit DHI

N limit Tamala Stn 
Urticaceae

Parietaria cardiostegia

Parietaria debilis

* Urica uren

Violaceae

Hybanthus calycinus

Hybunthus floribundus subsp. floribundus

$\mathrm{N}$ limit Murchison House Stn.

\section{Xanthorrhoeaceae}

Xanthorrhoea aff drummondii

$\mathrm{N}$ limit KNP

Zannichelliaceae

Lepilaena preissii

Zygophyllaceae

Nitraria billardierei

Tribulus astrocarpus

Tribulus cistoides

Tribulus forrestii

Tribulus macrocarpus

Tribulus occidentalis

Tribulus platypterus

Tribulus sp. (KRN 11569)

Tribulus terrestris

Zygophyllum aff. simile (RD Royce 5997)

Zygophyllum ammophilum

Zygophyllum apiculatum

Zygophyllum aurantiacum

Zygophyllum billardierei

Zygophyllum compressum

Zygophyllum eremaeum

Zygophyllum fruticulosum

Zygophyllum glaucum

Zygophyllum iodocurpum

Zygophyllum kochii

Zygophyllum lobulatum

Zygophyllum ovatum

Zygophyllum retivalve

S limit DHI

S limit Hamelin Stn

$\mathrm{N}$ limit DHI

N limit DH 